Universidade de Brasilia (UnB)

Faculdade de Economia, Administração e Contabilidade (FACE).

Departamento de Economia (ECO)

Programa de Pós-Graduação em Economia

Mestrado Profissional em Economia

\title{
QUALIDADE DO GASTO NO SETOR PÚBLICO: \\ Um Estudo na Fundação Universidade de Brasília
}

TIAGO MOTA DOS SANTOS

BRASÍLIA/DF

2015 


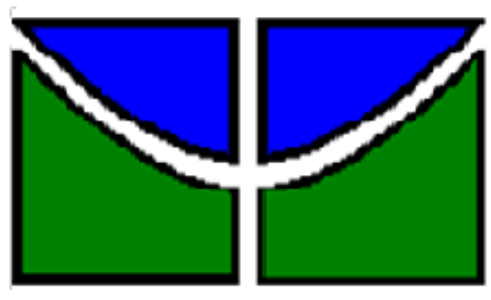

Universidade de Brasilia (UnB)

Faculdade de Economia, Administração e Contabilidade (FACE).

Departamento de Economia (ECO)

Programa de Pós-Graduação em Economia

Mestrado Profissional em Economia

\title{
QUALIDADE DO GASTO NO SETOR PÚBLICO: Um Estudo na Fundação Universidade de Brasília
}

\author{
TIAGO MOTA DOS SANTOS
}

Dissertação apresentada ao Programa de Pós Graduação em Economia ï PPGE - da Faculdade de Administração, Contabilidade e Economia (FACE) da Universidade de Brasília (UnB) como requisito parcial à obtenção do título de Mestre em Economia.

Orientador(a): Prof. Geovana Lorena Bertussi

\section{BRASÍLIA/DF}




\section{QUALIDADE DO GASTO NO SETOR PÚBLICO: Um Estudo na Fundação Universidade de Brasília}

Dissertação aprovada como requisito para a obtenção do título de Mestre em Economia do Programa de Pós-Graduação em Economia do Departamento de Economia da Universidade de Brasília (ECO/UnB). A Comissão Examinadora foi formada pelos professores:

Prof. Dra. Geovana Lorena Bertussi (Orientador)

Departamento de Economia ñ UnB

Prof. Dra. Andrea Felippe Cabello

Departamento de Economia ñ UnB

Prof. Dra. Danielle Sandi Pinheiro

Departamento de Administração - UnB

Brasília, 26 de junho de 2015. 
Dedico este trabalho....

A Deus;

Aos meus avós;

Aos meus pais;

A minha amada esposa;

$E$ aos meus filhos. 


\section{AGRADECIMENTOS}

Agradeço a...

A Deus pelo dom da vida.

A Prof. Geovana Lorena Bertussi por acreditar no meu potencial, colaborar e orientar de forma irrefutável essa dissertação.

A Universidade de Brasília por me proporcionar a honra de estudar e representá-la como aluno.

Aos professores do Departamento de Economia, em especial àqueles que ministraram disciplinas essências à nossa formação durante o curso.

Aos membros da banca examinadora.

Aos servidores do Departamento de Economia pelo apoio, muitas vezes silencioso, mas fundamental.

Aos meus colegas de curso.

Aos meus amigos e colaboradores da Diretoria de Contabilidade e Finanças/UnB pelo apoio e paciência no decorrer do curso.

Aos meus pais por me ensinarem que estudar me tornaria uma pessoa melhor.

Por fim, a minha amada esposa e meus filhos pela paciência e compreensão durante a realização deste curso. 


\section{RESUMO}

O objetivo deste trabalho foi verificar, por meio de um estudo de caso sobre a qualidade do gasto público na UnB, se houve aumento dos gastos públicos com ensino superior no período de 2003 a 2013, se adveio, essa elevação nos gastos proporcionou crescimento físico e um maior acesso a universidade no período proposto. Os gastos públicos federais com educação cresceram no período estudado, porém e a partir de 2007, com a implantação do REUNI, é que o governo passou a dar mais atenção para essa área. Após análise dos dados verificou-se na UnB, no período de 2003 a 2013, que o Governo Federal aportou mais recursos na universidade e esses recursos proporcionaram o crescimento da UnB visualizado no período. Porém, esse crescimento tem duas dimensões bem explícitas, uma delas foi o crescimento econômico e social que a universidade obteve e a outra foi causada pela deficiência no planejamento das ações na universidade, pois o crescimento também provocou aumento nas despesas de custeio.

Palavras-chaves: Universidade de Brasília, Receita, Despesa e Investimento. 


\begin{abstract}
The objective of this study was to determine, through a case study on the quality of public spending in UNB, if there was an increase in public spending on higher education from 2003 to 2013, was stemmed, this increase in spending provided physical growth and greater access to university in the proposed period. Federal government spending on education grew during the study period, however, and from 2007, with the implementation of REUNI, is that the government started to pay more attention to this area. After analyzing the data found on the UNB in the period 2003-2013, the federal government contributed more resources at the university and these resources have provided the growth of UNB displayed in the period. However, this growth has two very explicit dimensions, one of which was the economic and social growth that the university obtained and the other was caused by a deficiency in the planning of actions at the university, because growth also caused an increase in operating expenses.
\end{abstract}

Keywords: University of Brasilia, Revenue, Expenditure and Investment. 


\section{LISTA DE GRÁFICOS}

Gráfico 01 Gastos do Governo Federal com Ensino Superior (2003 a 2013). 56

Gráfico 02 Evolução da Receita Própria - UnB (2003 a 2013). 61

Gráfico 03 Receita por Departamentos ï UnB (2003 a 2013). 62

Gráfico 04 Receita por Unidade ï UnB (2003 a 2013). 63

Gráfico 05 Evolução da Despesa Orçamentária - UnB (2003 a 2013). 64

Gráfico 06 Despesas de Pessoal x Despesas de Custeio- UnB (2003 a 2013). 65

Gráfico 07 Investimentos Realizados na UnB (2003 a 2013). 73 


\section{LISTA DE TABELAS}

Tabela 01 Composição da Classificação da Natureza do Gasto. 51

Tabela 02 Despesas do Governo Federal por Função (2003 a 2013). 53

Tabela 03 Evolução Orçamentária da UnB (2003 a 2013). 59

Tabela 04 Discriminação das Outras Despesas Correntes-UnB (2003 a 2013). 66

Tabela 05 Discriminação Investimentos na UnB (2003 a 2013). 74

Tabela 06 Indicadores Gerais de Desempenho da UnB (2003 a 2013). 79

Tabela 07 Número de Formados na UnB (2003 a 2013). 80 


\section{LISTA DE ABREVIATURAS}
a.a
- Ao Ano.
BACEN
- Banco Central.
BAES
- Bloco de Salas de Aula Norte Eudoro de Sousa.
BCE
- Biblioteca Central - UnB.
BNDE
- Banco Nacional do Desenvolvimento Econômico.
BNDES - Banco Nacional do Desenvolvimento Econômico e Social.
BSA SUL - Bloco de Salas de Aula Sul.
CDT
- Centro de Desenvolvimento Tecnológico - UnB.
CEAD
- Centro de Ensino a Distância - UnB.
CEFTRU
- Centro de Formação de Recursos Humanos em Transportes Urbanos - UnB.
CESPE
- Centro de Seleção e de Promoção de Eventos - UnB.
CET
- Centro de Excelência em Turismo.
CF-88
- Constituição Federal em 1988.
CRVD - Companhia Vale do Rio Doce.
CSN - Companhia Siderúrgica Nacional .
CST - Consumo, subsídios e transferências.
ENEM - Exame Nacional do Ensino Médio.
FACE - Faculdade de Administração, Contabilidade e Economia - UnB.
FAL - Fazenda Água Limpa.
FEF / CO - Faculdade de Educação Física / Centro Olímpico - UnB.
FGTS - Fundo de Garantia por Tempo de Serviço.
FINATEC - Fundação de Empreendimentos Científicos e Tecnológicos.
FLAAC - Festival Latino-Americano e Africano de Arte e Cultura.
FMI
- Fundo Monetário Internacional.
FUB - Fundação Universidade de Brasília.
FUBRA - Fundação Universitária de Brasília.
GO - Goiás.
HUB - Hospital Universitário de Brasília - UnB.
HVET - Hospital Veterinário - UnB.
IB
- Instituto de Biologia - UnB. 
IED - Investimento externo direto.

IGT - Investimentos totais do governo.

INEP - Instituto Nacional de Estudos e Pesquisas Educacionais Anísio Teixeira.

INSS - Instituto Nacional de Seguridade Social.

IOF - Imposto Sobre Operações Financeiras.

IPOL - Instituto de Ciências Políticas - UnB.

IREL - Instituto de Relações Internacionais - UnB.

JK - Juscelino Kubitschek.

LDO - Lei de Diretrizes Orçamentárias.

LOA - Lei Orçamentária Anual.

LRF - Lei de Responsabilidade Fiscal.

MQO - Mínimos Quadrados Ordinários.

ND - Não Disponível

OCDE - Organização para a Cooperação e Desenvolvimento Econômico.

ORTN - Obrigações reajustáveis do tesouro nacional.

PAC - Programa de Aceleração do Crescimento.

PAEG - Programa de Ação Econômica do Governo.

PETROBRAS - Petróleo Brasileiro S/A.

PIB - Produto Interno Bruto.

PNAES - Programa Nacional de Assistência Estudantil.

PND - Plano Nacional de Desenvolvimento.

PPA - Plano Pluri Anual.

PSI - Processo de substituição de importações.

$\mathrm{R} \$ \quad-$ Reais.

REHUF - Programa de reestruturação dos hospitais universitários.

REUNI - Plano de Reestruturação e Expansão das Universidades Federais.

SAEB - Sistema de Avaliação do Ensino Básico.

SFH - Sistema Financeiro da Habitação.

SIAFI - Sistema de Administração Financeira.

STN - Secretaria do Tesouro Nacional.

UnB - Fundação Universidade de Brasília.

URV - Unidade Real de Valor.

US\$ - Dólar. 
SUMÁRIO

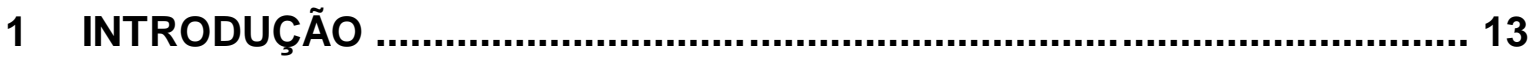

1.1 Contextualização e Formulação do Problema …............................................................

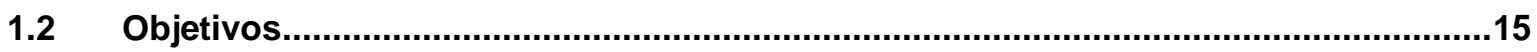

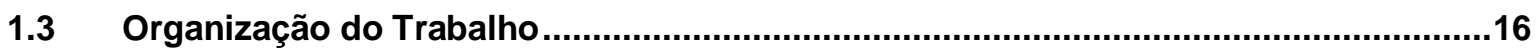

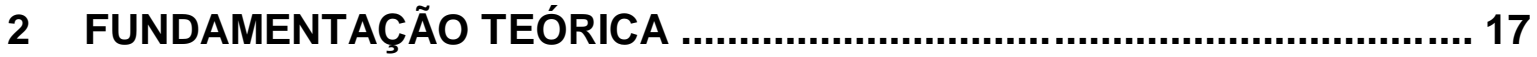

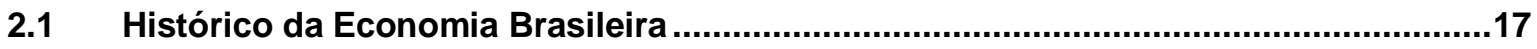

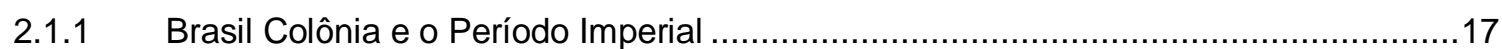

2.1.2 O Brasil República e o Ciclo do Café....................................................................19

2.1.3 A Industrialização, o Processo de Substituição de Importações e o Regime Militar....21

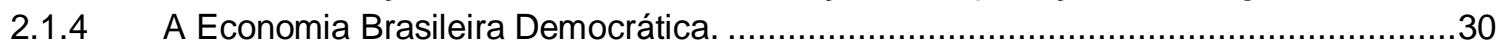

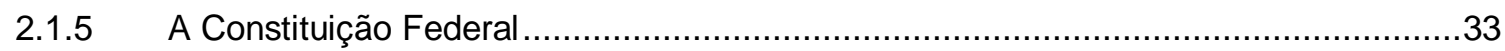

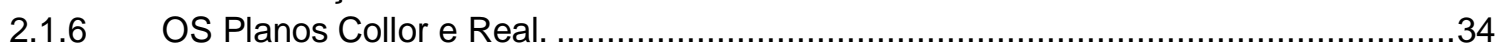

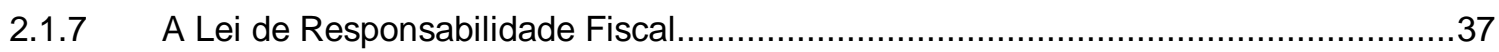

2.2 O Gasto Público e sua Relação com o Crescimento Econômico..................................40

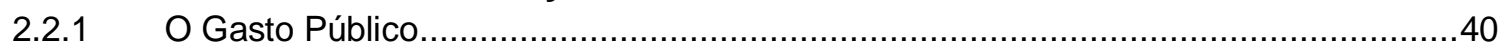

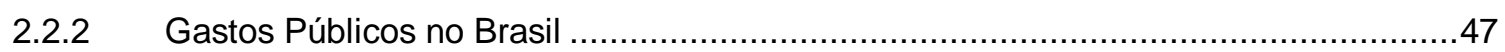

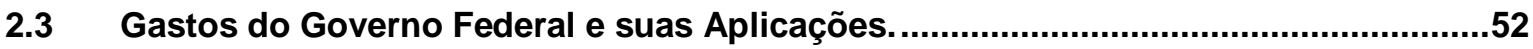

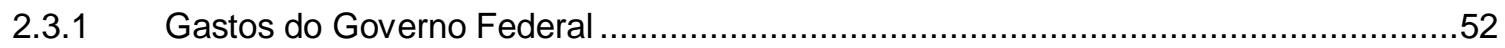

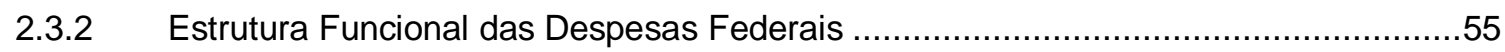

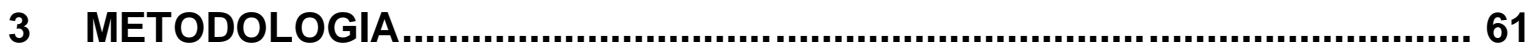

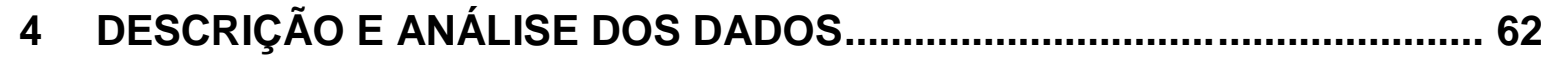

5 CONCLUSÃO

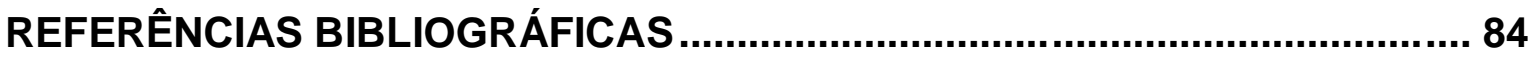




\section{INTRODUÇÃO}

\subsection{CONTEXTUALIZAÇÃO E FORMULAÇÃO DO PROBLEMA}

Em tempos de crise econômica um assunto que vem à tona é a qualidade do gasto do público, ou seja, como o Governo está gastando os recursos financeiros obtidos através da arrecadação de impostos, pois, segundo Netto (2010) um maior gasto não significa melhor qualidade do serviço público.

Os gastos públicos podem ser definidos como sendo uma preferência política dos governantes no que tange aos serviços que ele proporciona à população, além disso, evidenciam o custo da quantidade e da qualidade destes e dos bens oferecidos pelo governo (RIANI, 1997).

No Brasil o cenário econômico é de pessimismo, iniciamos o ano com um novo mandato presidencial de esquerda, diversos direitos trabalhistas conquistados ao longo dos anos foram revistos a fim de reduzir o custo deles, vários incentivos fiscais foram cancelados no intuito de se incrementar a arrecadação de impostos, o desemprego aumentou e um rigoroso ajuste fiscal foi anunciado a fim de conter o aumento inflacionário.

Mas, não é novidade no Brasil a constante luta contra a inflação, historicamente o país conviveu com diversos planos econômicos que foram criados para conter o aumento da inflação e promover o crescimento econômico, principalmente após a queda das exportações de café na metade do século passado. Até 1994 o país vivenciava taxas muito altas de inflação. Porém, na década de 80 o cenário foi pior, pois a inflação acumulava taxas de $100 \%$ ao ano, foi também na década de 80 que o país sofreu na tentativa de conter a inflação dado que nesta década houve o desabastecimento de produtos alimentícios no país.

Com a implantação do Plano Real, em julho de 1994, o Brasil alcançou o tão sonhado controle inflacionário, uma vez que em agosto de 1994 a inflação registrada foi de $1,7 \%$ (IBOVESPA, 2012) e ainda conseguiu promover a estabilidade da moeda (o Real). 
Nesse contexto econômico inserem-se as Universidades Federais que segundo Santos (2013), a política adotada para gerir o ensino superior pelo Ex. presidente Fernando Henrique Cardoso (1994 a 2002) era apoiada num viés neoliberal reflexo do novo ambiente capitalista. Essa política optou por deixar em segundo plano o ensino superior (e o serviço público em geral), devido à drástica redução no financiamento do governo federal, combinado com a saída de servidores públicos, além do encolhimento de salários e dos limites orçamentários destinados às IFES, especialmente para as rubricas de Outras Despesas Correntes e Investimentos. Isso tudo com a finalidade de conter o gasto público e consequentemente um possível descontrole inflacionário.

Ainda segundo Santos (2013) os governos de esquerda que sucederam o Ex. presidente Fernando Henrique Cardoso, Lula (2003 a 2010) e Dilma (2010 a 2014), procuraram criar condições para a recuperação e sustentação financeira das instituições públicas de ensino superior já existentes, além disso, promoveram a interiorização do ensino superior pelo país com a criação de novas Universidades e procuraram aumentar o acesso ao ensino superior por meio de linhas de crédito e com o aumento na oferta de vagas nas Universidades Públicas através do Reuni.

Atualmente o Brasil conta com 63 Universidades Federais, 321 Campi e atende a 275 Municípios de acordo com o Relatório do MEC instituído pela Portaria $\mathrm{n}^{\circ}$ $126 / 2012$.

Segundo o Ex. Ministro da Educação, Mercadante (2013):

ñNa última década, o orçamento do Ministério da Educação cresceu 205,7\%, ao passar de R \$33,3 bilhões em 2003 para R \$ 101,86 bilhões este ano (2013). Apesar dessa ampliação orçamentária, a educação brasileira precisa de ainda mais recursosò.

Neste contexto histórico e econômico encontra-se a Universidade de Brasília, fundada em 1962, foi a primeira Universidade Federal a ser dividida em Institutos Centrais e Faculdades. Seguindo essa perspectiva foram criados os cursos tronco, nos quais os alunos tinham a formação básica e, depois de dois anos, seguiam para os Institutos e Faculdades. 
Nessa perspectiva esse trabalho procura analisar a qualidade do gasto público por meio de um estudo de caso na Universidade de Brasília no período de 2003 a 2013 e responder ao seguinte questionamento: Houve aumento dos gastos públicos com ensino superior no período de 2003 a 2013, se adveio, essa elevação nos gastos proporcionou crescimento físico e um maior acesso a Universidade de Brasília?

\subsection{OBJETIVOS}

O objetivo geral deste trabalho é verificar, por meio de um estudo de caso sobre a qualidade do gasto público na UnB, se houve aumento dos gastos públicos com ensino superior no período de 2003 a 2013 e essa elevação nos gastos proporcionou crescimento físico e um maior acesso a UnB no período estudado.

A fim de atingir o objetivo geral, foram estabelecidos objetivos específicos tais como:

a. Verificar se houve aumento do gasto público na função educação superior no período compreendido entre 2003 e 2013;

b. Analisar como se comportaram: as Receitas, as Outras Despesas Correntes e os Investimentos na UnB no período compreendido entre 2003 e 2013;

c. Demonstrar se houve crescimento físico e ampliação do acesso na UnB no período compreendido entre 2003 e 2013;

d. Expor e interpretar os resultados obtidos através da pesquisa; 


\subsection{ORGANIZAÇÃO DO TRABALHO}

Este trabalho está organizado em cinco capítulos, incluindo esta introdução. No capítulo dois é apresentado o referencial teórico que traz um histórico de como economia brasileira enfrentou o descontrole inflacionário e as questões fiscais, além disso, faz uma revisão da literatura nacional e estrangeira a respeito da qualidade do gasto público e sua relação com o crescimento e por fim traz um panorama geral dos gastos do governo federal, por função, no período estudado. O capítulo três detalha a metodologia utilizada no trabalho. O capítulo quatro analisa o comportamento das receitas, de outras despesas correntes e dos investimentos realizados na $\mathrm{UnB}$ no período estudado além de expor e interpretar os resultados obtidos enquanto que as conclusões finais são expostas no capítulo cinco deste trabalho. 


\section{FUNDAMENTAÇÃO TEÓRICA}

\subsection{HISTÓRICO DA ECONOMIA BRASILEIRA}

\subsubsection{Brasil Colônia e o Período Imperial}

O século XV foi uma época de grandes descobertas, neste Portugal reinava como potência mundial, econômica, social e cultural constituindo-se o primeiro e o mais duradouro império colonial de amplitude global.

Foi no século XV que o Brasil foi descoberto, também por Portugal, neste os Portugueses tiveram muita dificuldade com os habitantes da nova colônia, formado basicamente por índios, que não se submeteram à disciplina imposta pelos portugueses e ainda reduziram-se drasticamente por conta de doenças contraídas dos primeiros colonizadores.

O Brasil não era considerado algo valioso por Portugal. Embora seu território fosse imenso, não trouxe a inesperada sorte econômica obtida pelos espanhóis em suas conquistas, isto é, metais preciosos e uma população ampla, estável e bem organizada (BAER, 2011).

A organização socioeconômica brasileira no início do século XVI foi conduzida por meio de Donatários, indivíduos que gozavam de prestígio político junto a Portugal e recebiam terras na colônia (Capitanias) para povoá-las e desenvolvê-las com seus próprios recursos tornando a Colônia Brasileira em um empreendimento comercial combinado com aspectos de subgoverno privado.

Nesse contexto de governo as linhas gerais da política a ser seguida eram formuladas na Europa e a operacionalização era deixada por conta dos Governadores e Conselhos Municipais que ñeram dominados por Fazendeiros e/ou Senhores de Engenho e o centro da vida social econômica concentrava-se nas grandes plantações costeiras de açúcarò (BAER, 2011, p. 33). 
O Brasil foi introduzido no cenário econômico internacional por meio do açúcar, primeiro produto a ser exportado em larga escala. O principal polo de produção foi a Zona da Mata Nordestina, local de acesso privilegiado e fácil escoamento da produção. Porém, com a mão de obra escassa, os índios que habitavam o Brasil não foram disciplinados para o trabalho na lavoura, a colônia foi obrigada a importar escravos africanos, principalmente de Angola, para o trabalho com a lavoura de cana de açúcar.

A exportação de açúcar foi lucrativa para os fazendeiros e aqueles envolvidos na comercialização, financiamento, expedição e comércio de escravos. Os comerciantes também obtiveram lucros com as importações, visto que a colônia era quase que totalmente dependente de produtos estrangeiros manufaturados e mesmo de alguns alimentos importados (BAER, 2011).

Ao final do século XVII as exportações de açúcar começaram a declinar por conta do excesso de oferta do produto. Sua causa foi o desenvolvimento de uma crescente oferta do produto nas colônias inglesas, holandesas e francesas, que tinham acesso facilitado aos mercados dos países de origem (BAER, 2011).

O legado que o açúcar deixou foi negativo. Não houve melhoria tecnológica para sustentar e melhorar o plantio, os recursos humanos mantiveram-se subdesenvolvidos e a distribuição de renda era extremamente concentrada. Dos lucros resultantes grande parte foi enviada à colônia, a intermediários do comércio e o que sobrou para os Senhores de Engenho foi gasto com bens de consumo importados e não em melhorias técnicas e de infraestrutura (BAER, 2011).

O ouro, do ponto de vista econômico, alterou centro de atividade econômica do Brasil para o Centro ï Sul. Este ciclo iniciou o desenvolvimento de um setor artesanal e estimulou o surgimento de grupos bancários privados, além de diversas cidades, suprindo as necessidades dos setores de mineração e comercial (BAER, 2011).

O incremento da mineração transformou o Rio de Janeiro, em 1763, na capital do Brasil e no principal centro exportador de minérios pelo qual entravam os artigos importados e manufaturados. Não demorou para que as mais importantes casas comerciais, instituições financeiras e vários outros serviços lá se instalassem (BAER, 2011). 
Com a valorização da colônia o governo português aumentou seus controles administrativos. As regiões de mineração eram supervisionadas com o propósito de minimizar a evasão do pagamento à Coroa de um quinto do ouro extraído. Foram proibidas as navegações particulares, foram criados monopólios especiais de comércio, a manufatura local era controlada e os bens fornecidos pela metrópole não podiam ser produzidos no Brasil (BAER, 2011).

Em 1807 Portugal é invadido pela França, obrigando a família real portuguesa a ir para o Brasil e se estabelecer no Rio de Janeiro. Sua chegada trouxe a Colônia diversos benefícios econômicos: a fundação do Banco do Brasil, a importação de uma prensa tipográfica, o fim dos controles mercantilistas, a criação de novos empregos, houveram investimentos na infraestrutura da cidade, a criação de instituições educacionais e, por fim, procuraram incentivar a instalação de estabelecimentos industriais (a indústria não obteve sucesso dado o poder que a Grã Bretanha exercia na época) (BAER, 2011).

Durante o século XIX, o Brasil, por conta de sua economia agroexportadora, adaptou-se facilmente à ordem econômica imposta pela Grã Bretanha - centro industrial do mundo. A economia brasileira dependia de um produto primário de exportação: o café (principalmente após 1840) e de alguns secundários (açúcar, algodão e cacau). Durante quase todo século XIX, a economia brasileira estava aberta ao capital e aos produtos manufaturados estrangeiros (principalmente os ingleses), que fluíam para dentro do país e destinavam-se a formar infraestrutura financeira, comercial e de transportes (BAER, 2011).

\subsubsection{O Brasil República e o Ciclo do Café.}

O final do século XIX foi marcado pelo fim da escravidão, pela Proclamação da República e pelo ciclo do café. Outro fenômeno ocorrido nesta época foi o fomento à imigração que o Governo promoveu principalmente nas Regiões Sudeste e Sul. O estimulo a imigração foi um substituto eficaz para o investimento em educação, com breve duração, como meio de otimizar a capacidade dos trabalhadores na economia (BAER, 2011). 
Além disso, os imigrantes foram fundamentais para o Ciclo do Café, pois as fazendas paulistas de café empregavam trabalhadores livres antes da abolição da escravatura (BAER, 2011).

O café foi introduzido no Brasil no início do século XVIII, cultivado como uma especialidade era consumido nas residências e nos cafés mais importantes da Europa. Com a Revolução Industrial houve uma melhora nos padrões de vida europeu e norteamericano e esse aumento na renda levou consigo há um aumento na demanda por café nessas regiões. Consequência disso, no Brasil o café tornou-se a maior commodity agrícola exportada no final de século XIX (BAER, 2011).

O primeiro polo de produção cafeeiro no Brasil foi o Rio de Janeiro, às técnicas de produção eram rudimentares, a mão de obra escrava e o transporte da produção era obsoleto. Por volta de 1880, à medida que as terras cariocas tornaram-se inférteis, São Paulo ascendeu como principal polo de produção de café no país. Essa ascensão foi promovida pela construção, com capital e mão de obra ingleses, de uma estrada de ferro que ligava São Paulo capital ao Porto de Santos e de outras ferrovias que ligavam o interior do estado ao Porto para escoamento da produção (BAER, 2011).

Na primeira década do século $\mathrm{XX}$, à medida que a produção de café superava a demanda mundial tornando o mercado superaquecido e ocasionando uma queda nos preços, o Estado de São Paulo, com intuito de estabilizá-los e manter a produção em níveis aceitáveis, proibiu o plantio de novas mudas durante cinco anos e, em 1906, deu início ao primeiro projeto de valorização (chamado de Convênio de Taubaté). Utilizando, primeiro, a arrecadação conseguida com as taxas de exportação e, depois, empréstimos estrangeiros (garantidos pelo governo central), São Paulo comprou grandes quantidades de café que eram sonegadas ao mercado a fim de estabilizar os preços (BAER, 2011).

Com as elevadas condições de rentabilidade da economia cafeeira os recursos existentes no Brasil convergiam para essa atividade. Essa convergência criou a base para a chamada superprodução de café que se configurou como uma tendência. Além disso, a política de sustentação desta era reforçada pela desvalorização cambial e pela política de valorização do café. Porém, em 1930, dois elementos conjugaram-se: produção nacional era enorme e a economia mundial entrou numa das maiores crises de sua história (GREMAUD, 2002). 
A depressão no mercado internacional de café logo se fez sentir e os preços vieram abaixo. Isso obrigou o governo a intervir, comprando e estocando café e desvalorizando o câmbio, com o objetivo de proteger o setor cafeeiro e ao mesmo tempo sustentar o nível de emprego e de renda dessa economia. Ficava claro que a situação da economia brasileira, dependente das exportações de um único produto agrícola, era insustentável. Mesmo porque a defesa do café por meio de estoques era problemática e eles não conseguiam ser repostos no mercado, sendo o governo obrigado a queimar boa parte durante as décadas de 30 e 40 (GREMAUD, 2002).

A crise dos anos 30 foi um momento de ruptura no desenvolvimento econômico brasileiro. A fragilização do modelo agroexportador trouxe à tona a consciência sobre a necessidade da industrialização como forma de superar os constrangimentos externos e o subdesenvolvimento. Não foi o início da industrialização brasileira, mas foi o momento em que a industrialização passou a ser meta prioritária da política econômica (GREMAUD, 2002).

\subsubsection{A Industrialização, o Processo de Substituição de Importações e o Regime Militar.}

A industrialização brasileira tomou um alento decisivo somente após 1930, quando a crise mundial de 1929 impossibilitou o país de continuar operando no tradicional modelo primário exportador. Nessa fase, iniciou-se a substituição, por produção interna, de alguns produtos anteriormente importados, notadamente os bens de consumo não duráveis (VICECONTI, 1977).

Um dos traços mais marcantes da economia brasileira a partir de 1930 é a expansão do setor industrial. Este, após 1933, começou a liderar as taxas de crescimento da renda e do emprego, ao mesmo tempo em que as culturas de exportação sofriam os revezes da crise internacional (FONSECA, 2003).

A crise da agro-exportação criava condições para que a economia se direcionasse ao mercado interno, o que contou com a política econômica governamental a seu favor. Iniciou-se, assim, um período de aproximadamente cinco décadas $ð$ que duraria até o final da década de 1970, com a conclusão dos investimentos do II PND 
(Plano Nacional de Desenvolvimento), do governo Geisel ð que é conhecido como processo de substituição de importações (PSI) (FONSECA, 2003).

Ao longo de três décadas o PSI modificou a economia brasileira, industrializando-a e urbanizando-a. Neste período, o Governo reviu sua política cambial a fim de desestimular as exportações de produtos agrícolas, a indústria não era competitiva graças ao protecionismo governamental e a elevada demanda por importações estabelecia-se graças ao investimento industrial e ao aumento da renda (GREMAUD, 2002).

Alguns mecanismos de proteção à indústria foram utilizados no PSI, os principais foram: desvalorização real do câmbio, controle de câmbio, taxas múltiplas de câmbio e elevação das tarifas aduaneiras. Contudo a geração de divisas se tornava complicada e o PSI só era viável graças ao capital estrangeiro, na forma de dívida externa ou investimento direto (GREMAUD, 2002).

Nesse período houve um crescimento considerável do Estado, aumentando sua participação na economia, essa ampla participação estatal gerava um tendência ao déficit público e forçava o recurso ao financiamento inflacionário, na ausência de fontes adequadas de financiamento (GREMAUD, 2002).

O aumento da participação estatal ficou evidenciado por meio da: adequação do arcabouço institucional, a indústria que alterou substancialmente a legislação trabalhista que incentivava o trabalhador rural a migrar para indústria, geração de infraestrutura básica que neste ínterim destacaram-se os sistemas de transporte e energia e o fornecimento de insumos básicos (GREMAUD, 2002).

É neste ponto o Estado atua complementando o setor privado, destacam-se a criação da Companhia Siderúrgica Nacional (CSN), Companhia Vale do Rio Doce (CVRD), Petrobras, diversas hidrelétricas, as Teles, Universidades Federais, etc; e a captação e distribuição de poupança, pois o Estado executava parte das atribuições dos intermediários financeiros (Banco do Brasil e BNDE). A primeira fase do PSI encerrouse com o fim da Era Vargas, naquela época a base política do governo estava decadente, a crise cambial avançava e a inflação crescia (GREMAUD, 2002).

O Plano de Metas, adotado no governo de Juscelino Kubitschek (JK), pode ser considerado o auge da industrialização brasileira. Concebido após a posse do Presidente 
prestou-se a apontar os setores com deficiência em investimentos (públicos, privados ou estrangeiros) e, dentro de cada setor impôs um escopo e incumbindo-se de ter um objetivo para cada alvo definido (ALMEIDA, 2004).

O plano pode ser dividido em três pontos: investimentos em infraestrutura (destacam-se neste os setores de transporte e energia elétrica); estímulo ao aumento da produção de bens intermediários (neste se destacam cimento, carvão, zinco, etc); e incentivos à introdução dos setores de consumo duráveis e de capital (neste destacou-se a indústria automobilística). Outra fase do plano, que não estava compreendida em sua proposta original, foi a construção de Brasília (ALMEIDA, 2004).

O Plano cumpriu seus objetivos, aparentemente, que resumidamente foi a aceleração da industrialização e a interiorização do desenvolvimento. Porém, o legado deixado pelo Plano de Metas situou-se no surgimento de um surto inflacionário que se deveu a dois fatores: (i) a emissão destinada a cobrir os investimentos governamentais; (ii) a falta de contrapartida fiscal, unida ao fato de que nenhum esquema especial de sustentação financeira do Plano havia sido formulado (ALMEIDA, 2004).

Considerando os aspectos econômicos, ressalta-se que o período após o Plano de Metas teve que se haver com o seu legado, com destaque para a aceleração inflacionária. Dessarte, até 1967, exerceu-se uma política econômica limitante. Com intuito de conter o processo inflacionário, buscou-se monitorar os gastos públicos, reduzir crédito e rechaçar os exageros da política monetária (GREMAUD, 2002).

Outro aspecto ressaltado na época era a necessidade de reformas institucionais que formassem um quadro favorável à retomada dos investimentos. Vários problemas colocavam-se nesse sentido, em especial a ausência de mecanismos de financiamento adequados para o setor público que se encontrava com elevado déficit, devido aos gastos realizados no Plano de Metas (GREMAUD, 2002).

É neste cenário de crescimento econômico, inflação alta e déficit público que o governo JK encerrava seu ciclo, em virtude desses problemas fora eleito para presidente Jânio Quadros com expressivo apoio popular e para vice João Goulart.

Jânio Quadros governou o país por menos de um ano, seus atos não tiveram o efeito esperado e em 1961 renunciou ao cargo. A situação política no Brasil á época era instável, além disso, os Militares impediram o retorno de João Goulart (que estava na 
China quando houve a renuncia de Jânio), levando ao Congresso Nacional, numa atitude conciliatória, a mudar o regime de governo no país para o parlamentarismo e assim João Goulart assumiria a presidência da república com poderes reduzidos (o regime parlamentarista no Brasil durou pouco tempo, por conta da pressão de João Goulart, e após um plebiscito voltou-se ao regime presidencialista) (ASSUNÇÃO, 2010).

Diante do cenário político ï econômico desfavorável, João Goulart buscou apoio em seus aliados. Porém, esse período de incertezas provocou diversas agitações que terminaram por criar um clima conspiratório no país que desagradou principalmente os militares e os setores mais conservadores da sociedade civil. Com isso em $1^{\circ}$ de Abril de 1964 os militares promoveram ño Golpeò, tomaram o poder e nomearam, por meio de votação indireta no Congresso, Castello Branco como Presidente (ASSUNÇÃO, 2010).

O início, conturbado, do regime militar brasileiro caracterizou-se por ilustrar um caso de ñnítida ausência de correlação entre democracia e desenvolvimento e de alta correlação entre autoritarismo e reforma econômicaò (GIAMBIAGI, 2011, p. 50). O país atravessava uma de suas piores crises, visto que durante 1963, a economia brasileira vivenciou uma estagnação da atividade econômica que foi acompanhada do crescimento inflacionário (GIAMBIAGI, 2011).

Em um cenário econômico desfavorável o Ministro Roberto Campos, em abril de 1964, providencia um diagnóstico e o submete ao Presidente, neste documento intitulado ñA Crise Brasileira e Diretrizes de Recuperação Econômicaò, duas linhas principais de superação da crise ganhariam força e seriam implementadas: o Programa de Ação Econômica do Governo (PAEG, que tinha como meta combater a inflação) e as reformas estruturais (fiscal, tributaria e financeira) (GIAMBIAGI, 2011).

No tocante as reformas estruturais, especificamente à reforma fiscal, um dos objetivos do PAEG foi à promoção do ajuste fiscal. A meta deste era a redução do déficit, em contrapartida, o governo criaria condições para: combater à inflação, aumentar a poupança, financiar a elevação dos investimentos públicos e o estimulo ao crescimento econômico (GIAMBIAGI, 2008).

As metas da reforma tributária eram a elevação da arrecadação do governo e a racionalização do sistema tributário. Em suas medidas, incluiu-se a troca do imposto 
sobre vendas incidente sobre o faturamento por um sobre a circulação de produtos (ICM) incidente sobre o valor adicionado de cada etapa da comercialização (GIAMBIAGI, 2008).

Ao tratar da reforma financeira faz $\ddot{i}$ se necessário contextualizar o cenário à época dado que no inicio dos anos 60, o sistema financeiro era particularmente deficiente e inexistia um mercado de capitais. Além disso, havia a Lei de Usura que combinada com a alta inflação da época desestimulavam a poupança, o investimento em títulos de renda fixa e outros. Com este cenário os déficits fiscais eram financiados basicamente pela emissão de moeda (GIAMBIAGI, 2008).

Um grande avanço institucional na condução da política monetária e do financiamento do déficit público foram as criações: do Banco Central (Lei 4.595 de 1964), a correção monetária aplicada aos títulos públicos representados pelas obrigações reajustáveis do tesouro nacional (ORTN), a criação do Sistema Financeiro da Habitação (SFH) e do Fundo de Garantia por Tempo de Serviço (FGTS - que se tornou uma importante fonte de recursos para o SFH) (GIAMBIAGI, 2008).

Em termos gerais, os objetivos colocados pelo PAEG foram: acelerar o ritmo de desenvolvimento econômico, conter o processo inflacionário, atenuar os desequilíbrios setoriais e regionais, aumentar o investimento e com isso o emprego e corrigir a tendência ao desequilíbrio externo. Além disso, o programa diagnosticou três fatores sobre as causas da inflação que eram: o déficit público, a expansão do crédito às empresas e os aumentos salariais por cima dos ganhos de produtividade. Estes elementos provocariam a expansão dos meios de pagamento, causando, dessa forma, a propagação da inflação (BASTIAN, 2013).

De 1968 até 1973 a economia progrediu fortemente resultando num PIB de 11\% ao ano puxado por bens de consumo durável e pelo de bens de capital. Além disso, neste período esse ritmo de crescimento foi acompanhado de queda da inflação e de melhora no Balanço de Pagamentos, que anotou crescentes superávits durante o período. Justifica-se o uso do termo ñmilagreò, nesse período, em função das relações macroeconômicas: direta entre crescimento e inflação e a inversa entre crescimento econômico e saldo do Balanço de Pagamentos (GIAMBIAGI, 2011). 
Outras interpretações sobre os fatores determinantes do ñmilagreò encontradas na literatura podem ser divididas em três grupos, não necessariamente excludentes, e que enfatizam a política econômica no período, o cenário internacional favorável e as reformas promovidas pelo PAEG (GIAMBIAGI, 2008).

Outras medidas no campo macroeconômico foram fundamentais para explicar o desempenho extraordinário das exportações. No que tange a política monetária houve uma grande expansão real da moeda e do crédito (que foi direcionado ao setor privado. Nas exportações, o estímulo governamental assumiu diversas formas, entre as quais se destaca a introdução do sistema de minidesvalorizações cambiais conhecido também como crawlin peg (GIAMBIAGI, 2008).

Essas medidas ajudam a explicar o excepcional desempenho exportador durante o ñmilagreò. taxas de crescimento anuais médias de $24 \%$ do valor (em US\$) das exportações, e de 39\% no caso de manufaturados. Quanto ao cenário externo da época fatores como a criação do mercado eurodólares, no final da década de 60 , permitiram ao Brasil ampliar seu endividamento externo por meio de empréstimos com juros de $2 \%$ ao ano e ainda houve o aumento no fluxo de investimento externo direto (IED) para o Brasil, que dobrou de patamar no início dos anos 70 (GIAMBIAGI, 2008).

Em conjunto, o aumento do endividamento externo e os fluxos de IED asseguraram a grandeza, no exterior, do ñmilagreò, na forma de um balanço de pagamentos superavitário e com taxas de crescimento econômico na casa dos dois dígitos (GIAMBIAGI, 2008).

O célere crescimento durante o milagre econômico intensificou o desequilíbrio entre a capacidade produtiva de bens de consumo e de bens intermediários, que foi agravado pelo choque do petróleo em 1973 (GOUVEA e LIMA, 2013). O choque causou uma recessão mundial e afetou o Brasil drasticamente, visto que neste período $80 \%$ do petróleo consumido no país era importado (BAER, 2011), além disso, a condução da economia brasileira destoava dos demais países, pois era desproporcional agiliza-la a partir de grandes projetos sob o comando estatal, quando diversos países se organizavam à nova realidade advinda do choque no preço do petróleo (FONSECA, 2008). 
O cenário internacional exigia um ajuste não só na substituição de importações de petróleo e insumos em geral, como também a alteração da composição setorial da economia brasileira com a finalidade de reduzir importações ou aumentar exportações. Foi nesse contexto que o governo do General Ernesto Geisel lançou, em 1974, o II Plano Nacional de Desenvolvimento (II PND) (GOUVEA e LIMA, 2013).

O II PND propôs a mobilização do país para o rápido crescimento econômico, sem superaquecimento, controlando a inflação e mantendo o equilíbrio do balanço de pagamentos, com alto nível de reservas (GOUVEA e LIMA, 2013). Suas metas eram substituir as importações de produtos industriais básicos (como aço, alumínio, cobre, fertilizantes, produtos petroquímicos) e bens de capital, além disso, promover a expansão da infraestrutura econômica (energia hidráulica e nuclear, produção de álcool, transportes e comunicações) (BAER, 2011).

Em suma os objetivos do II PND eram: agir com uma forte política contracíclica diante do impacto causado pelo choque do petróleo e manter uma razoável taxa de crescimento, um nível de emprego e de consumo; mudar a estrutura da economia brasileira através da substituição de importações, diversificação e expansão de exportações. (BAER, 2011).

Os principais resultados alcançados pelo II PND foram: o aumento na produção de aço dado que as metas estabelecidas no II PND apontavam para a produção de aço em 22,3 milhões de toneladas até 1979, porém a produção acabou atingindo, nesse ano, 13,9 milhões de toneladas, alcançando $63 \%$ do total das metas do plano; o setor de energia mostrou resultados positivos, verificou-se que a prioridade de aumento da produção do petróleo ampliou-a bastante, passando de 27\% em 1974 para $70 \%$ em 1980. Tal aumento decorreu principalmente dos investimentos aplicados no refino e transporte do petróleo, culminando, dessa forma, em resultados significativos de produção de até $17 \%$ a.a, no período de 1979-1986. Além desse aumento na produção do petróleo, é importante também frisar que a produção de energia alternativa, como a energia elétrica ligada à cana-de-açúcar, foi muito significativa em 1974 e 1979, com aumentos anuais de $12 \%$ e $9 \%$, respectivamente. Além disso, outros setores, que também foram muito importantes para o crescimento econômico do país, como os bens de capital e comunicações corroboraram para os resultados surpreendentes da economia brasileira durante o II PND (SOUZA, 2004). 
Contudo, na consecução do II PND, o Estado acolheu diversas obrigações, com a finalidade de manter o crescimento e o funcionamento da economia. Pois, as baixas taxas de juros praticadas no mercado internacional proporcionou ao Estado a capacidade de pagá-los, contudo assumiu o risco de que alterações nas taxas poderia impossibilitar os pagamentos. O agravamento da propensão de financiamento do Estado, que dividiu os custos no período do II PND, seria a adversidade enfrentada pela economia brasileira no futuro (GREMAUD, 2002).

Internamente a situação fiscal do País estava em declínio e era agravada com: redução na carga tributária; o aumento no volume de transferências, com destaque para os juros sobre a dívida interna; as estatais eram focos de déficits, devido ao enorme passivo financeiro e aos controles tarifários e, finalmente, o orçamento estava contaminado por várias operações fiscais e apresentava déficit decorrente das operações creditícias do governo (GREMAUD, 2002).

O desequilíbrio externo e a aceleração inflacionária eram causados pelo excesso de demanda interna que se materializava no déficit público. É neste cenário que, em 1979, o governo Figueiredo inicia seu mandato com Mário Henrique Simonsen no comando da economia com foco no controle da demanda agregada. Porém, a crise persistia e a ameaça de uma profunda queda da atividade econômica levou à grande reação política e à substituição do ministro no final de 1979 (GREMAUD, 2002).

O novo ministro, Delfim Netto, propôs e o governo reconheceu a necessidade de tomar medidas enérgicas e um novo pacote econômico foi introduzido com os seguintes objetivos: a) maxidesvalorização do cruzeiro; b) fim dos subsídios à exportação; c) fim do depósito antecipado para as importações; d) eliminação de outros incentivos fiscais; e) aumentos nos preços dos serviços públicos; f) tributação sobre lucros inesperados nas exportações agrícolas; g) extinção da Lei dos Similares; e h) fim das exigências de depósitos sobre aportes de capital e redução da alíquota do imposto de renda devido sobre a remessa de juros (BAER, 2011).

Além dessas, outras medidas, de acordo com Gremaud (2002), foram promovidas: a) início da Secretária Especial das Empresas Estatais (SEST); b) aprovação da Lei 6.708; e c) a prefixação da correção monetária e cambial, em 1980, com o objetivo de conter a inflação com um abalo psicológico. 
O objetivo dessas medidas eram resolver de uma só vez a supervalorização da moeda e aliviar as pressões políticas para que fossem extintos os subsídios às exportações. Embora a desvalorização e o aumento dos preços dos serviços públicos tenham causado aumento na inflação, esperava-se que essas medidas fossem somente um acontecimento de curto prazo e que a extinção dos incentivos fiscais fosse suplementar a receita do governo e, assim, conter à expansão monetária (BAER, 2011).

Os resultados obtidos, em 1980, com esse conjunto de medidas não foram satisfatórios, a inflação atingiu os $100 \%$ ao ano, em função do aumento dos preços públicos, da semestralidade salarial e da maxidesvalorização cambial. Além disso, houve o agravamento da crise econômica internacional no pós-guerra, por conta da segunda crise do petróleo, e do aumento das taxas de juros internacionais. Esses acontecimentos unidos ocasionaram o perecimento das contas externas, alargando a dívida externa e conduzindo à maior perda de reservas. Houve também o aumento da especulação, que ocorreu: a) devido à maxidesvalorização cambial; b) e em segundo o resultado da prefixação causou uma perda nos ativos financeiros. Com o encolhimento do sistema financeiro, em 1980, apontando recursos para a especulação com estoques (basicamente adiantando importações) (GREMAUD, 2002).

A piora na situação cambial obrigou o governo, já em 1980, a reverter a política econômica e a adotar uma política ortodoxa, denominada ajustamento voluntário, pois ainda não recorreria ao FMI e à renegociação da dívida. O diagnóstico permaneceu sendo o tradicional excesso de demanda interna. Além disso, as dificuldades para renovar empréstimos externos, juntamente com o aumento das taxas de juros, levaram a política interna a reduzir a necessidade de divisas, por meio do controle da absorção interna (GREMAUD, 2002).

Nesse contexto de taxas de juros elevadas e dificuldade na obtenção de recursos muitos países em desenvolvimento tiveram problemas com a dívida externa. No Brasil o processo de ajustamento iniciou-se, em 1980, e aprofundou-se no final de 1982 -sob a tutela do Fundo Monetário Internacional (FMI). A política adotada baseava-se: a) na contenção da demanda agregada por meio da redução do déficit público, com a redução do salário real e do desemprego gerado pelo quadro recessivo; e b) em restabelecer o arcabouço de preços relativos conveniente ao setor externo, nesse sentido ocorreram desvalorizações da moeda, elevação do preço dos produtos advindos do petróleo, 
estímulos à competitividade da indústria brasileira, por meio do controle dos preços públicos, dos subsídios e estímulos à exportação (GREMAUD, 2002).

O resultado dessa política de ajustamento foi uma recessão em 1981 e 1983, e baixo crescimento em 1982. Com grande queda na renda per capita no período. A política foi bem sucedida no tocante ao comércio exterior, observando-se reversão no saldo da balança comercial, passando de um déficit em 1980 para um superávit recorde em 1984. O sucesso do ajustamento externo deveu-se em parte à própria recessão, que levou a uma grande queda nas importações, paralelamente aos estímulos e ao aumento das exportações (GREMAUD, 2002).

O lado controverso do ajustamento era o equilíbrio das contas internas, que não se resolveria com a geração de superávits externos, visto que $80 \%$ da dívida era oriunda do setor público, consequência da estatização da dívida externa, visto que a maior parte da geração do superávit ocorria na iniciativa privada. Para o governo obter as divisas, ele teria que gerar um superávit fiscal compatível com a transferência externa, ou emitir moeda, ou ainda endividar-se internamente (GREMAUD, 2002).

A geração de superávit fiscal era inviável, pois a situação fiscal pública estava deteriorada desde o II PND e sendo agravada pelo ajustamento externo. A emissão de moeda era incompatível com a política de controle da absorção interna, manutenção de taxas de juros elevadas e tentativa de controle inflacionário. $\mathrm{O}$ endividamento interno foi à alternativa utilizada, a operacionalização dele se dava por meio da venda de títulos públicos. Esse processo acelerou a deterioração das contas públicas e ampliou o grau de indexação da economia em função das condições internas de negociação desta dívida interna (GREMAUD, 2002).

\subsubsection{A Economia Brasileira Democrática.}

A condução da política econômica, de 1985 até 1994, elegeu o combate a inflação como meta, isso foi tentado de várias formas e com uma série de planos econômicos, que tinham por base o diagnóstico da inflação inercial, trazendo o congelamento de preços como ator principal, sendo que a cada um incorporavam-se novas características, aperfeiçoando os anteriores, na tentativa de não se incorrer nos mesmos erros e assim causando quedas repentinas, e pouco duradouras, na inflação. 
Entre os planos destacam-se: Cruzado (1986), Bresser (1987), Verão (1989), Collor (1990 a 1991) (GREMAUD 2002).

O Plano Cruzado, concebido em fevereiro de 1986, tinha a mete de ñextirpar o câncer da inflaçãoò no Brasil. Naquela época o diagnóstico para a inflação era de que esta vinha de tempos passados, ou seja, ela se reproduzia através da existência de mecanismos formais e informais de indexação da economia. Neste sentido, a causa para inflação era ela mesma (OLIVEIRA, 1987).

O cerne do Plano Cruzado era a desmontagem dos mecanismos de indexação da economia e o congelamento de seus preços. Além disso, o plano contou com um grande apoio popular, no primeiro mês de existência, março de 1986, houve um processo de deflação no país que manteve o processo inflacionário em níveis bastante reduzidos nos meses que se seguiram (OLIVEIRA, 1987).

Com a inflação controlada e os preços congelados o plano causou na economia um excesso de demanda por produtos de consumo não duráveis, chegou-se ao ponto de haver problemas com abastecimento de produtos alimentícios. A situação mais grave era das empresas estatais, utilizadas à exaustão em tempos precedentes, o congelamento surpreendeu-as com seus preços exacerbadamente defasados e suas finanças completamente deterioradas (OLIVEIRA, 1987).

Durante os primeiros meses o Plano Cruzado foi bem sucedido no controle da inflação. Entretanto, ele fracassou porque foi incapaz de erradicá-la, por provocar grandes distorções e uma acentuada crise econômica e financeira (BRESSERPEREIRA, 1988).

A economia brasileira antes do Cruzado estava totalmente indexada, neste cenário antecessor lidávamos com taxas altas -quase estáveis- de inflação, com este plano o sistema de indexação foi abolido. Quando a inflação reapareceu em dezembro de 1986, a interdição legal da indexação provocou uma crise financeira que resultou em uma enorme quantidade de insolvências e falências no Brasil (BRESSER-PEREIRA, 1988).

Outro fato marcante, em 1986, foi à criação da Secretaria do Tesouro Nacional (STN), por meio do Decreto $n^{\circ} 92.452$ que a vincula ao Ministério da Fazenda. A STN assumiu as atribuições da extinta Comissão de Programação Financeira e da Secretaria 
de Controle Interno do Ministério da Fazenda, incorporando também as funções fiscais até então desempenhadas pelo Banco Central e Banco do Brasil S/A (STN, 2015).

Sua criação representou um passo essencial para as finanças públicas no Brasil, pois se tornou o órgão central do Sistema de Administração Financeira Federal e do Sistema de Contabilidade Federal (STN, 2015).

Após a sua criação a meta da STN era organizar as contas públicas. O primeiro passo foi a substituição da conta movimento do governo no Banco do Brasil pela Conta Única do Tesouro no Banco Central (BACEN), permitindo que a administração e o controle das finanças fossem associados à execução financeira das unidades gestoras. E unificou os orçamentos, atrelando os gastos governamentais à prévia autorização do Congresso Nacional (STN, 2015).

Em junho de 1987 a inflação era de 26\%, o Ministro da Fazenda (Luiz Bresser Pereira) promoveu o segundo congelamento de preços da economia, denominado Plano Bresser (que tinha como objetivo de somente deter a inflação, não eliminá-la, evitando o nítido perigo de hiperinflação), era novamente um choque heterodoxo, tal como o Cruzado, que foi baseado na teoria da inflação inercial (BRESSER-PEREIRA, 1988).

O Plano Bresser foi um plano de emergência que, momentaneamente, conteve a inflação, interrompeu a queda dos salários, evitou a recessão, reverteu a crise financeira e reequilibrou o balanço de pagamentos. Além disso, congelou os preços por apenas três meses e manteve indexação na economia. Para o mentor do Plano o mais importante naquele momento era ñestabelecer o equilíbrio geral da economia, assegurando uma taxa razoável de lucro nos diferentes setores, do que refrear artificialmente a inflaçãoò (BRESSER-PEREIRA, 1988).

Ao contrário do Plano Bresser e semelhante ao Plano Cruzado, o Plano Verão realizou uma reforma monetária, desindexou a economia e paralisou as minidesvalorizações cambiais, mas não previu uma fórmula de indexação de salários. Pretendia obter melhor sorte do que o Plano Cruzado graças às políticas fiscal e monetária mais rígidas. Graças ao que seria uma ñpolítica ortodoxaò, em contraste com a ñpolítica heterodoxaò do Plano Cruzado (BRESSER-PEREIRA, 1989).

A eficácia da política ortodoxa do Plano Verão pode ser verificada quatro meses após sua implantação. No plano financeiro o déficit público aumentou devido à política 
de juros reais pagos pelos títulos públicos, a política monetária rígida não se materializou, a dívida pública interna cresceu, os salários médios reais declinaram e a produção industrial apresentou sinais de recessão. Mais graves do que esses resultados alcançados pelo plano, foi o prejuízo em termos de perda de credibilidade do governo e de crédito do Estado. A incapacidade do governo de controlar o déficit público, os erros cometidos em relação à taxa de juros e a desindexação da economia levaram a um agravamento da perda de sua credibilidade (BRESSER-PEREIRA, 1989).

\subsubsection{A Constituição Federal}

Outro fato relevante nas finanças públicas brasileiras foi a promulgação da Constituição Federal em 1988 (CF-88), que manteve a tradição das constituições anteriores, definindo de maneira detalhada os instrumentos de planejamento e orçamento. $\mathrm{O}$ modelo adotado na CF-88 é centralizado, dado que havia excessiva fragmentação orçamentária com programações e despesas fora do orçamento. Dessa forma, definiu-se um processo integrado de alocação de recursos, compreendendo as atividades de planejamento e orçamento, mediante a definição do Plano Plurianual, da Lei de Diretrizes Orçamentária e da Lei Orçamentária Anual (MATIAS-PEREIRA, 2010).

O planejamento passou a ser expresso no Plano Plurianual, e apresenta-se como o instrumento para o alcance das determinações contidas na CF-88. Trata-se de lei discutida e aprovada no âmbito do Congresso Nacional, que inclui todas as ações de governo para um período de 4 anos. A Lei Orçamentária Anual, por sua vez, deve refletir as diretrizes contidas na Lei de Diretrizes Orçamentária, que é responsável pelo elo entre o planejamento e o orçamento (MATIAS-PEREIRA, 2010).

Um item relevante e contido na $\mathrm{CF}-88$, que causou impacto negativo nas receitas para a União, é a repartição da receita arrecadada com Estados e Municípios. O regime militar sofreu intensa pressão por governadores e prefeitos por maior autonomia financeira. Com a transição do autoritarismo para a democracia, em 1985, as demandas por autonomia financeira, reconhecidas como indispensáveis ao exercício da autonomia federativa, ganharam força. Assim, a Assembleia Constituinte, instalada em 1986, foi dominada no capítulo tributário pelas forças da descentralização (REZENDE, 2010). 
Outros pontos que merecem destaque, em relação a CF-88 são: a) a emissão de moeda é competência exclusiva do Banco Central, b) é vedado a concessão de empréstimos pelo Banco Central ao Tesouro Nacional e a qualquer outro órgão e c) que as disponibilidades de caixa da União serão depositadas no Banco Central (CF-88, artigo 164).

Em suma a CF-88 marcou profundamente as finanças públicas brasileiras, seja aproximando o planejamento da execução orçamentária com a apreciação do Congresso Nacional, sendo repartindo receitas arrecadadas pela União com Estados e Municípios e definindo competências para a emissão de moeda e gestão do caixa pelo Banco Central.

\subsubsection{OS Planos Collor e Real.}

O Plano Collor ficou conhecido como aquele que bloqueou a liquidez da maior parte dos haveres financeiros em março de 1990. Porém, ele, ñnão foi um improviso diante do quadro adverso daquele momentoò, teve sua origem em debates que tratavam do fracasso dos planos anteriores principalmente nos choques heterodoxos do Governo Sarney, além disso, outros Presidenciáveis (Lula e Ulysses Guimarães) já tratavam o bloqueio como uma possível solução para o quadro econômico da época (CARVALHO, 2006).

O governo Collor inicia-se com adoção imediata de um plano que visava romper com a indexação da economia. Neste fito, as principais medidas foram as reformas monetária, administrativa/fiscal, congelamento de preços e desindexação dos salários em relação à inflação passada, mudança no regime cambial e mudança na política comercial (GREMAUD 2002).

A reforma monetária objetivou reduzir a liquidez da economia, com o bloqueio de cerca de metade dos depósitos a vista, $80 \%$ das aplicações de overnight e fundos de curto prazo e aproximadamente um terço dos depósitos de poupança. O intuito disso era o de evitar pressões de consumo e retomar a capacidade do BACEN de fazer política monetária (GREMAUD 2002).

A reforma administrativa/fiscal tinha como meta a promoção de um ajuste fiscal da ordem de $10 \%$ do PIB. Esse ajuste seria feito por meio da redução do custo de 
rolagem da dívida pública, suspensão dos subsídios, incentivos fiscais e isenções, ampliação da base tributária pela incorporação dos ganhos da agricultura, do setor exportador e dos ganhos de capital nas bolsas, tributação das grandes fortunas, IOF extraordinário sobre o estoque de ativos financeiros e fim do anonimato fiscal, mediante a proibição dos cheques e das ações ao portador. Além disso, promover-se-ia o programa de privatizações, a melhoria dos instrumentos de fiscalização e arrecadação tributária, controle sobre os bancos estaduais e outras medidas com foco na elevação da eficiência e redução do gasto público (GREMAUD 2002).

No que tange ao congelamento de preços e a desindexação dos salários, foi definida uma nova regra de prefixação de preços e salários que vigorou a partir de maio/1990; o regime cambial foi alterado para um sistema de taxas flutuantes; e houve o início do processo de liberalização do comércio exterior, reduzindo-se assim as tarifas de importação ao longo de 4 anos (GREMAUD 2002).

O bloqueio da liquidez parece ter sido preponderante no plano Collor. Com ele buscou-se retomar a capacidade de fazer política monetária ativa congelando o estoque de moeda. O impacto imediato foi uma grande desestruturação do sistema produtivo com corte nas encomendas, semiparalisia na produção, demissões, férias coletivas, redução nas jornadas de trabalho, redução nos salários, deflação, atraso nos pagamentos de dívidas, expansão no volume e no prazo dos créditos comerciais, desenvolvimento de meios de pagamento alternativos. Enfim, o choque sobre os estoques monetários gerou profunda desestruturação em termos de condições de emprego e de produção, provocando uma retração do PIB em 1990 (GREMAUD 2002).

Devido às pressões e o receio de uma recessão, iniciou-se logo após o plano a devolução da liquidez pelas chamadas ñtorneirinhasò do BACEN, o que levou a uma expansão da liquidez nos meses seguintes, mas de forma direcionada e desproporcional entre os setores da economia, pois apenas uma pequena parcela da sociedade ficou com os cruzados bloqueados e a partir de maio/1990, começou o relaxamento no controle de preços e salários, o que, juntamente com a monetização, levou a aceleração inflacionária. Portanto, quanto ao controle de liquidez, a grande preocupação foi com o estoque e não com o fluxo (GREMAUD 2002).

Quanto ao ajuste fiscal o governo, conseguiu sucesso, obtendo um superávit primário em 1990 (1,2\% do PIB). Porém o resultado obtido foi fruto, em sua maioria, da 
instauração do IOF, da redução dos gastos com a rolagem da dívida pública em virtude do confisco e de atrasos de pagamento do governo. Relativo à reforma administrativa/fiscal, o governo não conseguiu implementar a proposta de demissão de funcionários públicos, neste caso dependeria de uma emenda constitucional aprovada pelo Congresso Nacional onde não tinha o apoio político necessário. Outro ponto de destaque foi o início do programa de privatização que era colocado como um elemento central no processo de ajuste fiscal e patrimonial do setor público. Esse ponto foi controverso, pois a definição das regras do programa, a cargo do BNDES, foram alvo de críticas no que se refere aos ativos que seriam aceitos como pagamento (GREMAUD 2002).

No tocante ao setor externo suas políticas foram: o início do processo de abertura comercial com redução das tarifas, eliminação dos incentivos às exportações (serviu para diminuir os gastos públicos) e adoção do sistema de câmbio flutuante. Entretanto, com a aceleração inflacionária, a taxa de câmbio real sofreu valorização. Isso, combinado com os menores incentivos às exportações e a maior facilidade às importações, além da Guerra do Golfo, levou a uma deterioração do saldo da balança comercial. Nesse quadro, na ausência de um fluxo de capitais que possibilitasse a manutenção de um déficit em transações corrente, o BACEN se viu obrigado a intervir no mercado, levando a uma grande desvalorização da moeda, que contribuiu para fomentar o processo inflacionário. Esse fator foi um determinante para o fracasso do plano (GREMAUD 2002).

O Plano Collor teve seu desfecho com a volta da inflação elevada, este ficou mais conhecido pelo bloqueio de haveres, embora ñas demais medidas econômicas tenham influenciado muito mais profundamente o futuro do Paísò. (CARVALHO, 2006)

Instituído em 01 de julho de 1994 o Plano Real marcou profundamente a economia brasileira, ele surgiu em um ambiente econômico de elevada liquidez nos mercados financeiros, provocada pelo alto crescimento da economia norte americana, pela grande geração de riqueza nos seus mercados de capitais e em decorrência de um grande volume de comércio mundial (LAMEIRA, 2004). 
O plano pretendia controlar a inflação mediante a liberação da economia brasileira ao comércio mundial, especialmente às importações, com uma taxa de câmbio que apresentava elevada apreciação de nossa moeda frente ao dólar. Esse mecanismo de estabilização denominado âncora cambial gerava déficit em conta corrente que seria financiado pelo ingresso de capitais estrangeiros na forma de investimentos diretos e de investimentos estrangeiros de curto prazo que aproveitavam de altas taxas internas de juros (LAMEIRA, 2004).

Outro fator importante do Plano ocorreu antes da implementação deste, pois houve uma espécie de moeda transitória Ï denominada Unidade Real de Valor- que tinha a finalidade de promover a passagem para a nova moeda através de uma moeda-índice e não de um índice-moeda (LOPES, 2010).

Além da âncora cambial, de uma moeda transitória anterior ao Real outro ponto fundamental do Plano era o ajuste fiscal e a reorganização definitiva das contas públicas, visto que sem isto qualquer esforço de combate à inflação teria curta duração e estaria fadado ao fracasso (LOPES, 2010).

ñO Plano de estabilização que se implementou com sucesso foi composto destes dois elementos apresentados aqui de forma relativamente independente, quais sejam, o combate à inflação inercial pela URV e o controle das contas para contornar a crise fiscal no contexto da nova ordem globalò (LOPES, 2010, p. 5).

\subsubsection{A Lei de Responsabilidade Fiscal}

A Lei Complementar $n^{\text {o }}$ 101/2000, popularmente conhecida como Lei de Responsabilidade Fiscal (doravante LRF) foi aprovada doze anos após a promulgação da Constituição Federal de 1988 com alto índice de votos favoráveis ï 385 votos a favor, 86 contra e 04 abstençõesï ela está estruturada em 75 artigos e promove uma mudança institucional no trato com o dinheiro público constituindo-se no principal instrumento regulador das contas públicas no Brasil (SACRAMENTO, 2005).

Sua criação foi parte do esforço, promovido pelo governo federal à época, em reformas do estado para estabilizar a economia brasileira a partir do Plano Real que 
neste ínterim expos que o pilar central deste deveria ser o equilíbrio fiscal notadamente o elemento mais importante do Plano (LOPES, 2010).

Ela estabelece normas e condutas voltadas à administração pública com foco na gestão financeira e fiscal, com prevenção de riscos e correção de desvios capazes de afetar o equilíbrio das contas públicas, destacando-se o planejamento, o controle, a transparência e a responsabilização (DIAS e CAMPOS, 2010).

Em seu artigo $1^{\circ}, \S 1^{\circ}$ ela define responsabilidade na gestão fiscal que:

Pressupõe a ação planejada e transparente, em que se previnem riscos e corrigem desvios capazes de afetar o equilíbrio das contas públicas, mediante o cumprimento de metas de resultados entre receitas e despesas e a obediência a limites e condições no que tange a renúncia de receita, geração de despesas com pessoal, da seguridade social e outras, dívidas consolidada e mobiliária, operações de crédito, inclusive por antecipação de receita, concessão de garantia e inscrição em Restos a Pagar.

O equilíbrio fiscal é necessário para superação dos problemas que afetam o bem estar social tais como: inflação, taxas de juros restritivas, desemprego e insuficiência de serviços públicos como saúde, segurança e educação, além disso, o planejamento figura como ponto de partida para o entendimento da LRF (SACRAMENTO, 2005).

Ao adicionar uma série de relatórios e demonstrativos, objetivando comparar o que foi planejado com a execução orçamentária, permitindo conhecer as ações dos gestores públicos para assegurar o equilíbrio das contas públicas e estabelecendo em seu artigo 48 que tais instrumentos serão objeto de ampla divulgação, inclusive em meio eletrônico, a LRF contempla a transparência como um dos seus princípios norteadores (SACRAMENTO, 2005).

Com a LRF o controle das contas públicas foi aprimorado, consequência natural da transparência e da qualidade das informações, neste sentido os controles clássicos ou tradicionais da accountability horizontal são citados em seu artigo 59 quando se estabelece que a fiscalização será exercida pelo Legislativo, com o auxilio dos Tribunais 
de Contas, pelo sistema de controle interno de cada poder e pelo Ministério Público (SACRAMENTO, 2005).

A responsabilização como aspecto contundente da LRF, deverá ocorrer sempre que houver descumprimento das regras nela estabelecidas, sendo assim, para assegurar a efetividade desta foram criadas as sanções institucionais e pessoais (SACRAMENTO, 2005).

Em suma a LRF merece destaque, pois ela obriga ao gestor público zelar pelo dinheiro que o contribuinte recolhe, além disso, reprime gastos exorbitantes fixando limites para a despesa e contribui significativamente para que o processo de accountability avance no Brasil. 


\subsection{O GASTO PÚBLICO E SUA RELAÇÃO COM O CRESCIMENTO ECONÔMICO}

\subsubsection{O Gasto Público}

A seção 2.1 mostrou que durante o Regime Militar o crescimento econômico brasileiro foi significativo. Porém, o modelo adotado pecou pelos excessos nos gastos públicos que o governo efetuou para impulsionar a economia. O ápice do regime foi batizado de ñMilagre Brasileiroò na década de 70, que entrou em decadência, na década de 80, quando o governo não conseguiu mais estimular a economia, controlar a inflação e os níveis crescentes de concentração de renda e pobreza provenientes de seu projeto econômico baseado no maior gasto público.

O receio com os efeitos dos gastos públicos na economia é costumeiro, especialmente seus impactos sobre o crescimento econômico. Vários estudos sugerem que os gastos públicos podem elevar o crescimento econômico, aumentando a produtividade do setor privado. Por outro lado, um aumento dos gastos públicos financiados por impostos distorcivos e a ineficiência na alocação dos recursos podem superar o efeito positivo dessas externalidades (CÂNDIDO JÚNIOR, 2001).

Os gastos públicos constituem-se na principal peça de atuação do governo. Por meio destes ele estabelece uma série de prioridades no que se refere à prestação de serviços públicos e aos investimentos a serem realizados (RIANI, 2009).

Neste ínterim Silva (2007, p. 31) ensina que o estudo dos gastos públicos relaciona-se com a análise da intervenção do Estado na economia dos países, essencialmente, por meio da obtenção dos recursos disponíveis na sociedade e a sua realocação em bens e serviços públicos para atendimento das políticas de governo.

Porém, toda análise a respeito dos gastos públicos deve levar em consideração que os recursos são limitados e as necessidades ilimitadas, com isso o governo tem a difícil missão de administrar receitas e despesas de forma a atender aos anseios da sociedade em áreas mais precárias ou aquelas que possam produzir resultados satisfatórios e trazer maiores benefícios a esta (GONÇALVES, 2013).

Em geral a gestão dos gastos públicos é aplicada em qualquer nível de governo. No tocante às Universidades Públicas, onde o Reitor tem poderes limitados pelos 
Conselhos Superiores, a gestão dos recursos disponíveis é um enorme desafio. Pois, não é possível atender a todos os anseios da comunidade acadêmica, ou seja, como priorizar investimentos na construção de mais salas de aulas sem afetar a ampliação de programas de fidelização estudantil como auxilio moradia, por exemplo? Ou construir uma nova sede administrativa mantendo-se o mesmo nível de gasto com limpeza e vigilância?

Nesse sentido, uma forma de avaliar os gastos públicos é classificando-os em produtivos ou improdutivos. Gastos produtivos são aqueles utilizados de forma a atender a seus objetivos ao mínimo custo possível, de um modo geral são aqueles em que os benefícios marginais sociais dos bens ou produtos públicos são iguais ï ou superiores- aos custos marginais para obtê-los (CÂNDIDO JÚNIOR, 2001).

O conceito de gastos improdutivos é dado pela diferença entre o gasto efetivo e o gasto que minimiza o custo na obtenção do mesmo objetivo. Esta diferença é uma perda para a sociedade que tem um custo de oportunidade, ou seja, a aplicação desse recurso em outra finalidade (CÂNDIDO JÚNIOR, 2001).

Assim, utilizando um conjunto de regressões em cross-section no período de 1970 a 1980, Easterly e Rebelo (1993) verificaram que um aumento no gasto público com transporte e comunicação, para países em desenvolvimento, leva a um maior crescimento econômico. No caso das demais categorias de gasto público, as evidências não são conclusivas se eles constituem gastos produtivos.

Aschauer (1989) encontrou evidências de um impacto positivo do investimento público em estradas, ruas, sistemas de água e esgoto e outros sobre o crescimento econômico e a produtividade do setor privado nos Estados Unidos no período 19491985.

Destarte, a intervenção do governo na Economia torna-se cada vez maior, dado que, a partir dos três primeiros quartéis do século passado as funções deste expandiramse significativamente, contribuindo com os princípios teóricos que recomendavam a necessidade de intervenção governamental no sistema econômico, com o objetivo de estabilizar a moeda, ampliar a distribuição de renda e conter o processo inflacionário (REZENDE, 2010). 
O papel do governo no desenvolvimento é relevante devido à sua capacidade de incentivar direta ou indiretamente a acumulação dos determinantes de crescimento econômico. A acumulação de capital físico sofre influência dos gastos governamentais com formação bruta de capital fixo, nas várias esferas de governo. As três funções básicas deste na economia são a alocativa, a distributiva e de estabilização. A primeira baseia-se no fato de que uma alocação eficiente de recursos não pode ser auferida somente pelo mercado, onde o Estado entra via fornecimento de bens públicos. A função distributiva permite que a distribuição de renda se aproxime daquela considerada justa pela sociedade, e a função estabilizadora tem como objeto o controle da produção, do emprego, preços e equilíbrio do balanço de pagamentos, além do alcance de taxas apropriadas de crescimento econômico (RODRIGUES e TEIXEIRA, 2010).

Adequações na alocação de recursos são necessárias sempre quando não há condições que assegurem maior eficiência na utilização dos recursos disponíveis na economia mediante o funcionamento do mecanismo de determinação dos preços no mercado. Os casos mais relevantes referem-se à existência de economias externas ou problemas com a satisfação de necessidades coletivas. A construção de uma Universidade Pública, como exemplo, fomenta a expansão da atividade econômica numa região, além de promover um resultado positivo sobre o nível de renda nacional muito superior ao resultado individual do empreendimento do ponto de vista do setor privado (REZENDE, 2010).

A necessidade de ajustamentos na distribuição da renda, numa economia de mercado, pelos diferentes habitantes do país está condicionada à disponibilidade dos fatores de produção e aos respectivos níveis de produtividade. Nesse sentido, ao se utilizar critérios puramente econômicos de eficiência nas decisões relativas ao emprego dos fatores de produção, a distribuição da renda gerada pelos habitantes pode não ser considerada socialmente aceitável. Nesse caso, a correção de desigualdade na repartição do Produto Nacional poderia ser efetuada mediante intervenção governamental. Um dos processos mais utilizados consiste em utilizar a política de gastos governamentais, ampliando despesas de transferência que beneficiem direta ou indiretamente (mediante manutenção de serviços gratuitos como educação e saúde) as classes de renda mais baixa (REZENDE, 2010). 
O objetivo da estabilidade econômica é controlar o nível agregado de demanda, com o propósito de atenuar os impactos social e econômico de crises de inflação ou depressão. O controle desta implica intervir sobre o crescimento das despesas privada e governamental, com consumo ou investimento, por meio do controle dos gastos públicos, do crédito e dos níveis de tributação (REZENDE, 2010).

O gasto público tende a crescer à medida que a intervenção do Estado na economia aumenta. Nesse propósito, estudos relativos ao comportamento da despesa pública tem se destacado. Entre esses é oportuno citar as contribuições de Adolph Wagner e de Peacock e Wiseman quanto ao estabelecimento de teorias que expliquem o processo de evolução do setor público (MATIAS-PEREIRA, 2010).

Ao analisar o comportamento e a evolução das despesas públicas, Adolph Wagner, citado por Matias-Pereira, formulou a denominada ñLei de Wagnerò, que estabeleceu a seguinte proposição: ñà medida que cresce o nível de renda em países industrializados, o setor público cresce sempre a taxas mais elevadas, de tal forma que a participação relativa do governo na economia cresce com o próprio ritmo de crescimento econômico do paísò(MATIAS-PEREIRA, 2010, p. 49).

Ao explanar a ñLei de Wagnerò, Bird (1970) assinala três motivos para a concepção da referida: a primeira relaciona-se com o crescimento das funções administrativas e segurança que decorrem do processo de industrialização, inclusive com o aumento do número de bens públicos em razão da maior dificuldade na vida urbana; a segunda se relaciona com o aumento da promoção de bem-estar social (educação e saúde), cuja demanda aumentaria com o crescimento econômico do país; a terceira decorre do desenvolvimento de condições para a criação dos monopólios, incentivada por avanços tecnológicos e pela necessidade de aumento nos investimentos para os setores industriais, cujos efeitos seriam reduzidos por conta da intervenção direta ou indireta do governo no processo produtivo.

Peacock e Wiseman, citados por Rezende (2010), versam o crescimento das despesas públicas de forma diferente da Lei de Wagner. Para eles, o aumento dos gastos de governo é mais uma função da capacidade de obtenção de recursos do que da dilatação dos fatores que explicam o crescimento da demanda de serviços produzidos pelo governo. Isto é, o aumento das atividades do governo é limitado pelas 
possibilidades de expansão da oferta, e estas, por sua vez, limitadas pela capacidade de acréscimo na tributação.

Neste sentido, os indivíduos teriam costume diferente quanto à demanda de bens produzidos pelo governo e quanto à disposição de colaborar com os recursos fundamentais à produção desses bens. Em épocas normais, a resistência ao aumento da carga tributária seria suficiente para impedir um crescimento dos gastos, a despeito da pressão exercida pelo progresso da demanda. Esta, por sua vez, seria sentida quando grandes perturbações, política ou socioeconômica, contribuíssem para minimizar a resistência ao incremento na tributação. Este elevaria no mesmo instante os gastos aos novos níveis permitidos pelo incremento na disponibilidade de recursos. Essa relação de fatores exógenos sobre o desempenho dos gastos foi chamado de efeito translação, reconhecido como fator principal a explicar o processo evolutivo das despesas governamentais com base na análise empírica da experiência na Grã-Bretanha (REZENDE, 2010).

O processo inflacionário é mencionado como motivo capaz de induzir o efeito translação, que é típico e interessa à experiência brasileira. Ao passo que indivíduos sofram de ilusão monetária, o limite ao aumento dos gastos determinado pela resistência ao crescimento na carga tributária pode ser superado utilizando a inflação como um substituto para o aumento dos tributos. Nesse caso, a expansão dos gastos é financiada com a emissão de papel moeda, pelo mecanismo chamado de poupança forçada. $\mathrm{O}$ processo só funciona enquanto persistir a ilusão monetária, que tende a desaparecer à medida que perdura a inflação, o efeito sobre as despesas do governo no produto é transitório, assumindo, assim as características do efeito translação (REZENDE, 2010).

Além do efeito translação há outro importante no crescimento dos gastos públicos: o efeito concentração. Refere ï se à progressão da aglutinação das decisões em níveis elevados de governo simultaneamente com a própria expansão da participação deste na economia. Essa aglutinação é observada em países de organização federal, nos quais o mecanismo decisório é gradativamente centralizado nas mãos do Governo Federal, ao mesmo tempo em que a execução é atribuída aos governos locais. Os motivos principais para ocorrência do fenômeno informado estão associados ao objetivo simultâneo de centralização das decisões para compatibilizar os problemas de política fiscal com a formulação geral de política econômica, e de descentralização das 
atividades executivas para aumentar a eficiência da atuação do governo (REZENDE, 2010).

Para analisar o crescimento das despesas públicas, as contribuições teóricas informadas tendem a se complementar na tentativa de generalização de princípios que explicam o processo de crescimento dos gastos do setor público. De um lado, a análise proposta por Wagner enfatiza a renda per capita como principal variável a explicar a expansão da demanda de bens produzidos pelo governo. De outro, Peacock e Wiseman estabelecem que o crescimento da demanda estaria limitado pelas possibilidades de expansão da oferta, a qual é limitada pela possibilidade de crescimento da tributação. Isso expressa que, embora, no longo prazo, a participação dos gastos do governo na renda nacional cresça, o processo de crescimento deverá obedecer a um padrão alternado de períodos relativamente estáveis com outros de rápido crescimento (REZENDE, 2010).

Há uma ampla literatura que discute a relação entre gastos de governo e o crescimento econômico.

Neste sentido, a discussão sobre como os gastos públicos afetam o crescimento econômico baseia-se em duas correntes primárias: de um lado a linha Keynesiana -que os coloca como pertencentes à demanda efetiva, juntamente com o investimento e o consumo, e, portanto, é uma das formas de aquecer a economia e estimular o crescimento-; do outro lado está a linha ortodoxa ï fundamenta sua opinião sobre a relação gasto governamental e crescimento na teoria da equivalência ricardiana (segundo esta o consumidor alteraria suas probabilidades de gasto com consumo e de poupança de acordo com a política de tributação e gastos do governo) (FREITAS, NETO e LÔU, 2009).

John Maynard Keynes propôs, em sua obra a Teoria Geral do Emprego, do Juro e da Moeda, a utilização da política fiscal compensatória que preconizava o aumento do déficit público em épocas de recessão e a geração de superávits caso houvesse de ameaças de inflação (MATIAS-PEREIRA, 2010).

A essência da obra de Keynes ([1936],1996) é o emprego. Quando esse aumenta, a renda real agregada deve aumentar também, ou seja, quando a renda real agregada aumenta, o consumo agregado também cresce, porém não tanto quanto a renda. Como 
consequência, os empresários tenderiam a sofrer perdas se o aumento total do emprego se destinasse a satisfazer a maior demanda para consumo imediato. Assim, justifica-se que para qualquer volume de emprego deve existir um volume de investimento suficiente para absorver o excesso da produção total em determinado nível.

Neste caminho, Keynes apoia-se no expediente da política fiscal (gasto governamental e tributação) para aperfeiçoar o nível de emprego, o mecanismo para viabilizar tal situação seria alterar a propensão marginal a consumir da sociedade reduzindo os impostos e modificando a estrutura dos investimentos, através do aumento no gasto do governo. Sendo assim, a demanda agregada seria aumentada e, consequentemente, o emprego seguiria em igualdade de condições (FREITAS, NETO e LÔU, 2009).

Essa forma de política econômica é utilizada quando o governo não consegue financiar seu déficit fiscal de longo prazo. Assim, a saída para enfrentar tal situação consiste em utilizar uma política fiscal contracionista como forma de gerar receita $і$ através de aumento de impostos e redução dos gastos públicosï capaz de conceber um superávit primário (FREITAS, NETO e LÔU, 2009).

Por outro lado a linha ortodoxa de pensamento fundamenta sua opinião sobre a relação gasto governamental e crescimento na teoria da equivalência ricardiana. Esta proposição teórica expõe que, sob determinadas circunstâncias, uma mudança no padrão tributário no tempo Ï menor imposto agora, maior imposto no futuroï não afeta o dispêndio privado e, portanto, não afeta a poupança, o investimento ou a conta corrente nacional (SACHS e LARRAIN, 1995).

Inicialmente, uma redução tributária proporciona um crescimento de recursos. Neste sentido, os agentes beneficiados tendem aumentar seu consumo. Entretanto, o governo para compensar o acréscimo na dívida a incrementa com juros, que serão pagos com o aumento de impostos no futuro, portanto, uma redução fiscal é na realidade um adiantamento fiscal. Se o mercado fosse perfeito e os consumidores racionais, este adiantamento não produziria nenhum efeito sobre o consumo (FREITAS, NETO e LÔU, 2009).

Uma limitação da teoria ricardiana fundamenta-se no longo prazo de pagamento que o setor público possui quando contrata empréstimos em comparação com as 
famílias. Se o governo incentivar a economia por meio de redução de impostos, poderá compensar o benefício com acúmulo de dívida durante o longo prazo antes de incrementar os impostos no futuro. Neste caso, o acréscimo nos impostos não será pago pelos cidadãos presentes, mas por gerações futuras. Portanto, os cidadãos atuais vão enxergar a redução como uma queda real que não será abalada pelos futuros aumentos que os outros vão pagar. Assim, fica evidente que a redução na carga tributária proporciona um aumento de consumo e uma perda na poupança governamental (SACHS e LARRAIN, 1995).

\subsubsection{Gastos Públicos no Brasil}

No Brasil há diversos estudos sobre a relação dos gastos públicos com o crescimento econômico, porém a falta de consenso teórico e a ambiguidade nos resultados empíricos estimulam trabalhos que tentam buscar respostas principalmente na natureza dos gastos públicos (FREITAS, NETO e LÔU, 2009).

Freitas, Neto e Lôu (2009) definiram como lócus de pesquisa a região Nordeste e verificaram a influência dos gastos públicos sobre o PIB desta região. Eles justificam a escolha desta para análise pelo fato dela apresentar taxas de crescimento menores que outras regiões do Brasil e pela limitação de investimentos públicos de origem federal. Definido o lócus eles propuseram uma estimativa baseada em Mínimos Quadrados Ordinários (MQO), utilizando-se um modelo ad hoc com dados em painel para o período entre 1987 e 2006.

A partir da análise dos dados verificou-se que os gastos de capital se relacionam positivamente com o crescimento econômico, porém os dispêndios correntes possuem relação negativa com o crescimento em médio prazo no lócus escolhido. Notaram que o resultado obtido não contrariou a teoria keynesiana, pelo contrário, caminhou na contramão da equivalência ricardiana. Portanto, se a prioridade do governo for elevar o produto do Nordeste, o estudo propôs a contenção nos gastos de custeio e a ampliação do investimento público na região (FREITAS, NETO e LÔU, 2009).

Rocha e Giuberti (2005) aplicaram um modelo em dados em painel para os estados brasileiros, que buscou avaliar a questão do impacto da política fiscal sobre o crescimento econômico destes no período de 1986 a 2002. Os gastos foram 
decompostos em correntes e capital, depois foram separados, de acordo com sua classificação funcional, em cinco categorias: defesa, educação, saúde transporte e comunicação.

Averiguaram uma carência na literatura que trata da relação entre composição do gasto público e crescimento econômico. Nem a teoria econômica nem a evidencia empírica fornecem respostas claras para a questão de como a composição do gasto público afeta o crescimento econômico de longo prazo (ROCHA e GIUBERTI, 2005).

Rocha e Giuberti (2005) aplicaram um modelo em dados em painel para os estados brasileiros desenvolvido por Devarajan, Swarrop e Zou (1996) que estabeleceu a relação entre as participações do gasto público e a taxa de crescimento de longo prazo da economia. Concluíram que no longo prazo a relação entre os gastos correntes do Governo e crescimento econômico é negativa; para a relação dos gastos com capital e a taxa de crescimento é positiva e no caso dos gastos com defesa, educação, transporte e comunicação a relação destes com a taxa de crescimento econômico é positiva, a única exceção é a saúde que após a análise relacionou-se negativamente com a taxa de crescimento econômico.

Rodrigues e Teixeira (2010) promoveram uma análise comparativa dos gastos públicos por esfera de governo que teve como objetivo investigar a relevância do gasto de cada esfera de governo para o crescimento econômico brasileiro no período de 1948 a 1998. Além disso, pretenderam determinar qual categoria de gasto é mais produtiva sendo que estas foram separadas em duas: CST (consumo, subsídios e transferências) e IGT (investimentos totais do governo).

A fim de cumprir com o objetivo aventado utilizaram o modelo proposto por Feder (1983) que desagrega a economia em dois setores. Notaram que o maior gasto público com investimento deve ser priorizado, principalmente na esfera estadual, em detrimento dos gastos em consumo, subsídios e transferências. Além disso, ressaltaram que os gastos públicos podem impulsionar o desenvolvimento econômico, principalmente aumentando-se as atribuições dos estados em detrimento da União, e do investimento em detrimento dos gastos com consumo, subsídios e transferências (RODRIGUES e TEIXEIRA, 2010). 
Cândido Júnior (2001) buscou classificar os gastos públicos brasileiros, no período de 1947 a 1995, em produtivos e improdutivos. Para isso analisou teórica e empiricamente a relação entre gastos públicos e crescimento econômico no Brasil, de forma agregada, captando-se o balanço líquido da participação dos gastos sobre o produto interno.

A análise teórica sugeriu a existência de um nível eficiente de gastos públicos, ou seja, cada unidade monetária aplicada em bens públicos deve ser igual ao que se obtém desse bem em termos de produto marginal, em condições competitivas. Esta é uma condição de eficiência que estabelece o tamanho ótimo do governo (CÂNDIDO JÚNIOR, 2001).

O crivo empírico, avaliado por duas metodologias, mostrou -em termos agregados- os efeitos dos gastos públicos sobre o crescimento econômico no Brasil e concluíram que a proporção de gasto público no Brasil está acima do seu nível ótimo e que há indícios de baixa produtividade. Portanto, ao se elevar a carga tributária, os resultados sugerem uma transferência de recursos do setor mais produtivo para o menos produtivo. Os efeitos sobre o crescimento serão mais danosos quanto mais distorcivo for o sistema tributário e menos produtivo for o gasto público (CÂNDIDO JÚNIOR, 2001).

Rocha e Giuberti (2007) buscaram avaliar empiricamente o impacto do gasto público sobre o crescimento econômico sustentado, utilizando uma abordagem que procurou medir o impacto utilizando o modelo proposto por Devarajan, Swarrop e Zou (1996). Neste caso o gasto foi decomposto segundo sua categoria econômica, depois por suas funções e por último foi classificado em produtivo ou improdutivo, de acordo com o seu efeito sobre o nível de atividade, no período de 1986 a 2003 para os Estados brasileiros.

Concluíram que a relação entre composição dos gastos e o crescimento econômico dos Estados brasileiros no longo prazo foi: gastos com defesa, educação, transporte e comunicação com o crescimento econômico é positiva; gastos com capital e a taxa de crescimento é positiva e aparentemente não linear; e a relação entre os gastos correntes primários do governo e o crescimento econômico é aparentemente positiva e não linear também. Notaram que o efeito não linear demonstra a existência de um limite para os gastos com consumo (61\% da despesa orçamentária) e essa evidência solicita 
uma reorientação na composição dos gastos em direção aos investimentos, uma vez que esses têm um efeito positivo sobre o produto (ROCHA e GIUBERTI, 2007).

Ribeiro (2008) realizou uma análise quantitativo-comparativa com o objetivo de avaliar o desempenho e a eficiência do setor público para um conjunto de 17 países da América Latina (incluindo o Brasil) no período de 1998 a 2002.

Os resultados obtidos mostraram que Costa Rica, Uruguai e Chile foram os países que apresentaram os melhores desempenhos dos serviços e eficiência relativa dos gastos públicos. O Brasil ocupou a $11^{\circ}$ posição apresentando-se na média para a avaliação dos serviços públicos $\left(7^{\circ}\right)$ e abaixo da média quanto à eficiência do gasto (entre a $9^{\circ}$ e a $11^{\circ}$ ). Esse resultado é insatisfatório, considerando o lócus de pesquisa, e pode ser atribuído ao montante elevado das despesas do governo geral e ao pífio desempenho do subindicador de equidade. Porém, houve um progresso significativo nessa área graças à estabilidade econômica alcançada a partir da segunda metade dos anos 1990 e ao crescimento dos programas sociais (RIBEIRO, 2008).

Divino e Junior (2012) analisaram os efeitos da política fiscal sobre o crescimento da renda per capita dos municípios brasileiros no período 1991 a 2000, para isso utilizaram o modelo oferecido por Devarajam, Swarrop e Zou (1996), onde procuraram verificar como gastos públicos e a sua composição afetam o crescimento econômico. Averiguaram como o nível de renda per capita municipal influência na relação entre crescimento e gasto público e se há alguma não linearidade quadrática nessa relação que permita identificar uma composição ótima entre despesas correntes e de capital.

Os resultados mostraram um efeito positivo de gastos públicos, como proporção da renda local, sobre crescimento econômico municipal, esses permitiram avaliar como a composição de gastos correntes e de capital impactam o crescimento econômico. Neste sentido, municípios com renda per capita abaixo da linha de pobreza conseguem aumentar o crescimento econômico ao executar mais despesas correntes do que os outros que estão acima da linha de pobreza. O município pobre possui atividades econômicas de baixo dinamismo e nesse caso os gastos públicos representam importante fonte de renda, gerando empregos e demandando bens e serviços produzidos pelo setor privado. Esses gastos elevam a renda local e tornam as despesas públicas um elemento chave para promoção do crescimento econômico via efeito multiplicador (DIVINO e JUNIOR, 2012). 
Bertussi (2010) avaliou o impacto dos gastos públicos em transportes sobre o crescimento econômico dos estados brasileiros entre 1986 e 2007 utilizando dados em painel e um modelo de regressão quantílica. O resultado do estudo constatou que o investimento público no setor de transportes provoca efeito positivo sobre o desempenho econômico dos estados brasileiros, no longo prazo, além de contribuir potencialmente para a redução da desigualdade de renda entre eles.

Arraes e Teles (2001) verificaram o desempenho dos governos estaduais brasileiros, no período de 1981 a 1995, dividindo-os conforme suas regiões respectivas. O método utilizado foi semelhante ao proposto por Barro (1990). Concluíram que o nível tributário ótimo, dada a alocação dos gastos públicos no período, está entre uma margem de $11 \%$ a $15 \%$ do PIB. Sugeriram que a alocação dos gastos governamentais em educação, saúde e infraestrutura tornaria o governo brasileiro suficientemente produtivo e poderia elevar o Brasil ao patamar dos países desenvolvidos.

Em suma, diversos estudos mostraram, no caso do Brasil, que um maior investimento nas áreas da saúde, educação, transporte e infraestrutura poderiam, no longo prazo, elevar o país ao nível dos países desenvolvidos. Porém, gerir os gastos públicos é uma tarefa árdua, considerando que quanto maior o volume da receita maior será a cobrança de impostos. Portanto, conhecer a natureza das contas públicas é um fator determinante para qualidade do gasto, pois a redução no gasto público poderia contribuir para a redução na tributação. 


\subsection{GASTOS DO GOVERNO FEDERAL E SUAS APLICAÇÕES.}

\subsubsection{Gastos do Governo Federal}

A seção 2.2 trouxe um panorama geral sobre gastos públicos e sua relação com crescimento econômico, além de diversos estudos para o caso brasileiro onde se verificou que aumentando o investimento em setores como saúde, educação e infraestrutura poderia colocar o Brasil no patamar de países desenvolvidos.

Entretanto, para executar a despesa pública é necessário arrecadar recursos, provenientes de impostos, taxas, serviços, aluguéis, etc. A fim de que se realizem as políticas públicas em benefício da sociedade. Para que a execução da despesa e a realização da receita aconteçam faz-se necessário que as leis orçamentárias, instituídas pela CF-88, sejam aprovadas pelo Congresso Nacional.

No Brasil, o PPA se constitui na síntese dos esforços de planejamento de toda administração pública, orientando a elaboração dos demais planos e programas de governo com duração de quatro anos. A lei que o instituir estabelecerá de forma regionalizada as diretrizes, os objetivos e metas da administração pública federal para as despesas de capital e outras delas decorrentes e para os programas de duração continuada (GIACOMONI, 2009).

O elemento intermediário entre o planejamento (PPA) e a execução (LOA) é a LDO que foi concebida pela CF-88 e imbuída de mais atribuições pela LRF. A LDO compreenderá as metas e prioridades da administração pública federal, incluindo as despesas de capital para o exercício financeiro subsequente, orientará a elaboração da LOA, disporá sobre as alterações na legislação tributária e estabelecerá a política de aplicação das agências financeiras oficiais de fomento (GIACOMONI, 2009).

Segundo a LRF, cabe à LDO dispor sobre o equilíbrio entre as receitas e as despesas, as metas fiscais, os riscos fiscais, a programação financeira e o cronograma de execução mensal de desembolso, os critérios e formas de limitação de empenho, o controle de custos e avaliação dos resultados dos programas, as condições e exigências para transferências de recursos a entidades públicas e privadas, as formas de utilização e montante da reserva de contingência, as demonstrações trimestrais apresentadas pelo BACEN sobre o impacto e o custo fiscal de suas operações e a concessão ou ampliação 
de incentivo ou benefício de natureza tributária da qual decorra renúncia de receita. Além dos anexos de metas e riscos fiscais (GIACOMONI, 2009).

A operacionalização do orçamento anual fica a cargo da LOA, que conforme disposição constitucional constitui-se dos orçamentos fiscal, da seguridade social e de investimento das empresas.

Segundo Giacomoni (2009) o orçamento fiscal por sua abrangência e dimensão se constitui no principal dos três orçamentos e referem-se aos poderes, seus fundos e os órgãos e entidades da administração direta e indireta. $\mathrm{O}$ orçamento da seguridade social abrange as entidades e órgãos a ela vinculados ï saúde, previdência social e assistência social- da administração direta e indireta, bem como os fundos e fundações instituídas e mantidas pelo poder público. No que tange ao orçamento de investimento das empresas, que reflete uma preocupação dominante nos anos 80, este abrange os investimento realizados pelas empresas em que o poder público, direta ou indiretamente, detenha a maioria do capital social com direito a voto.

Em suma, o orçamento é o instrumento de planejamento de qualquer entidade e representa o fluxo de ingressos e aplicação de recursos em determinado período. Para o setor público, é de vital importância, pois é a lei orçamentária que fixa a despesa pública autorizada para um exercício financeiro (MCASP, 2014).

A despesa pública é o conjunto de dispêndios realizados pelos órgãos públicos, ou por aqueles que administram recursos públicos, para o funcionamento e manutenção dos serviços públicos prestados à sociedade (MCASP, 2014).

No Brasil os gastos públicos assumem diversas classificações, todas elas impostas por lei, que define a finalidade do gasto, a natureza econômica e o agente encarregado da execução do gasto (REZENDE, 2010).

No que tange à finalidade, os gastos são normalmente classificados em funções e subfunções. A classificação funcional, representada por cinco dígitos, segrega as dotações orçamentárias, buscando responder em que área de ação governamental o gasto será realizado. Ela foi instituída pela Portaria $n^{\circ} 42 / 1999$, do Ministério do Planejamento Orçamento e Gestão, e é composta de um rol de funções e subfunções prefixadas, que servem como agregador dos gastos públicos por área de ação governamental. A aplicação é obrigatória, no âmbito da União, dos estados, do Distrito 
Federal e dos municípios, pois permite a consolidação dos gastos do setor público em âmbito nacional (MCASP, 2014).

Quanto à natureza do gasto a classificação é composta por: categoria econômica, grupo natureza da despesa, modalidade de aplicação (função gerencial) e elemento da despesa. A classificação das despesas por categoria econômica inspira-se na contabilidade pública e objetiva dimensionar a participação do dispêndio governamental nos principais agregados da análise macroeconômica (REZENDE, 2010).

Tabela 01 ï Composição da Classificação da Natureza do Gasto.

\begin{tabular}{|c|c|c|c|}
\hline Categoria Econômica & $\begin{array}{c}\text { Grupo Natureza da } \\
\text { Despesa }\end{array}$ & $\begin{array}{l}\text { Modalidade } \\
\text { de Aplicação }\end{array}$ & $\begin{array}{c}\text { Elemento da } \\
\text { Despesa }\end{array}$ \\
\hline \multirow{3}{*}{3 - Correntes } & 1 Pessoal e Encargos Sociais & \multirow{6}{*}{$\begin{array}{c}\text { Função } \\
\text { gerencial. }\end{array}$} & \multirow{6}{*}{$\begin{array}{l}98 \text { elementos } \\
\text { específicos, } \\
\text { que detalham a } \\
\text { despesa. }\end{array}$} \\
\hline & 2 Juros e Encargos da Dívida & & \\
\hline & 3 Outras Despesas Correntes & & \\
\hline \multirow{3}{*}{4 - Capital } & 4 Investimentos & & \\
\hline & 5 Inversões Financeiras & & \\
\hline & 6 Amortização da Dívida & & \\
\hline
\end{tabular}

Fonte: MCASP, 2014.

O agente encarregado pela execução do gasto fica refletido na classificação institucional, composto de cinco dígitos, que reflete a estrutura de alocação dos créditos orçamentários e está estruturada em dois níveis hierárquicos: órgão orçamentário e unidade orçamentária (MCASP, 2014). Constitui unidade orçamentária o agrupamento de serviços subordinados ao mesmo órgão ou repartição a que serão consignadas dotações próprias (art. 14 da Lei $n^{\circ}$ 4.320/1964). Os órgãos orçamentários, por sua vez, correspondem a agrupamentos de unidades orçamentárias. As dotações são consignadas às unidades orçamentárias, responsáveis pela realização das ações (MCASP, 2014). 


\subsubsection{Estrutura Funcional das Despesas Federais}

A distribuição por funções dos gastos federais foi implantada pelo inciso I do $\S$ $1^{\circ}$ do art. $2^{\circ}$ e $\S 2^{\circ}$ do art. $8^{\circ}$, ambos da Lei no 4.320/64 e atualizadas a partir da edição da Portaria do MPOG 42/1999. Na Tabela 02 são apresentados os valores, referentes ao período de 2003 a 2013, dos gastos em cada função do governo federal. Em seguida, é feita uma análise dos dispêndios federais por função neste período.

$\mathrm{Na}$ preparação da tabela 02 foi utilizado o conceito proposto por Pereira e Piancastelli (1996) de despesa não financeira da União, excluindo as subfunções administração financeira e transferências constitucionais e obrigatórias. Explica-se a utilização desse conceito por dois motivos: a) excluindo administração financeira retiramos uma distorção existente na contabilização desta subfunção, pois os refinanciamentos da dívida ao longo do ano são incorporados como amortizações de dívida, quando na verdade não representam desembolsos efetivos, mas apenas o mecanismo de rolagem; b) eliminando as transferências que serão alocadas aos estados e municípios gera-se um conceito de gasto efetivo do governo federal.

Os dados apresentados na tabela 02 são os valores efetivamente liquidados no período estudado, ou seja, são dados nominais que permitem identificar a forma de como se dividiu as atividades do governo federal no período de 2003 a 2013, demonstrando os principais objetivos da intervenção governamental na economia. A identificação das principais funções reflete as prioridades explícita ou implicitamente estabelecidas pelo Governo Federal, no período, para aplicações nos diferentes setores, tendo em vista a concretização dos objetivos nacionais de então.

De modo geral, conforme tabela 02, a estrutura dos gastos traduz um esforço do governo na execução das funções de previdência social e encargos especiais, pois durante o período estudado o gasto médio com essas funções foi de $\mathrm{R} \$ 980.955 .506 .900$ (78,83\% do total). O gasto com previdência social cresceu em progressão geométrica, triplicou-se o valor, comparando 2003 com 2013, além disso, o gasto médio nessa função no período foi de $\mathrm{R}$ \$ 274.894.131.505 (22,09\% do total). Em relação aos encargos especiais houve um crescimento controlado de 64,59\% comparando 2003 com 2013, em relação ao total o gasto médio foi de $\mathrm{R} \$ 706.061 .375 .395$ (56,74\% do total). 
Tabela 02 ï Despesas do Governo Federal por Função (2003 a 2013).

$\mathrm{R} \$ 1,00$

\begin{tabular}{|c|c|c|c|c|c|c|c|c|c|c|c|}
\hline Função & 2003 & 2004 & 2005 & 2006 & 2007 & 2008 & 2009 & 2010 & 2011 & 2012 & 2013 \\
\hline Administração & 7.362 .507 .102 & 8.917 .894 .124 & 9.061 .037 .677 & 10.016 .441 .370 & 12.614 .653 .331 & 13.085 .544 .272 & 17.052 .311 .939 & 17.689.787.295 & 16.917 .132 .075 & 19.665 .419 .153 & 19.908 .861 .725 \\
\hline Agricultura & 6.505 .710 .581 & 7.635.751.822 & 8.327 .650 .276 & 9.932 .567 .753 & 11.152 .293 .618 & 9.475.545.304 & 14.722 .850 .853 & 14.153 .547 .300 & 15.201.231.559 & 15.774 .341 .698 & 10.514 .432 .520 \\
\hline Assistência Social & 8.416 .353 .101 & 13.863 .295 .002 & 15.806 .087 .874 & 21.551 .140 .291 & 24.708 .958 .694 & 28.838 .816 .644 & 33.335 .541 .043 & 39.103 .421 .942 & 45.563 .647 .140 & 56.626 .228 .373 & 62.290 .382 .825 \\
\hline Ciência e Tecnologia & 1.993 .196 .406 & 2.607.080.738 & 3.274 .462 .390 & 3.703.455.224 & 4.210 .416 .611 & 5.069 .932 .495 & 6.190 .020 .531 & 7.325.387.986 & 6.779 .355 .090 & 7.594 .468 .324 & 8.611 .972 .534 \\
\hline Comércio e Serviços & 2.066 .541 .571 & 2.084 .429 .012 & 2.843.568.076 & 2.789 .802 .912 & 2.873.358.366 & 3.370 .754 .662 & 4.035.522.371 & 3.836 .931 .670 & 3.700 .203 .103 & 3.954 .030 .717 & 1.309 .487 .120 \\
\hline Comunicações & 641.494 .866 & 496.444 .548 & 481.222 .355 & 457.130 .731 & 880.796 .390 & 495.782 .210 & 534.288 .749 & 917.031 .484 & 787.621 .264 & 1.039 .782 .512 & 1.143 .540 .021 \\
\hline Cultura & 231.342 .791 & 323.920 .554 & 494.098 .178 & 551.988 .795 & 727.181.181 & 861.787 .147 & 1.119 .576 .844 & 1.339 .530 .014 & 1.360 .528 .082 & 1.849 .562 .047 & 896.331 .287 \\
\hline Defesa Nacional & 11.570 .137 .295 & 13.573 .310 .106 & 15.422 .398 .758 & 16.636 .098 .260 & 19.321 .715 .769 & 22.180 .133 .613 & 26.147 .139 .833 & 31.839 .142 .097 & 31.902 .743 .849 & 36.576 .094 .513 & 31.584 .333 .784 \\
\hline Desporto e Lazer & 159.851 .493 & 271.419 .136 & 423.069 .816 & 735.893 .789 & 1.412 .561 .469 & 961.216 .524 & 982.220 .417 & 1.032 .067 .612 & 1.148 .668 .755 & 1.253 .128 .906 & 400.049 .929 \\
\hline Direitos da Cidadania & 394.444 .982 & 550.343 .506 & 828.656 .979 & 954.336 .554 & 911.446 .109 & 1.466 .997 .747 & 1.569 .164 .091 & 1.765 .773 .719 & 1.331 .660 .224 & 1.256 .181 .455 & 704.366 .890 \\
\hline Educação & 14.224 .269 .574 & 14.532 .927 .063 & 16.187 .695 .350 & 17.336 .237 .935 & 21.498 .340 .861 & 25.068 .823 .155 & 36.679 .526 .521 & 44.061 .617 .777 & 52.909 .474 .149 & 65.364 .018 .393 & 68.361 .098 .936 \\
\hline Encargos Especiais & 614.092 .503 .302 & 530.604 .138 .500 & 663.417 .669 .943 & 678.747 .655 .844 & 643.750 .335 .053 & 626.830 .193 .604 & 707.868 .836 .814 & 708.195 .531 .318 & 795.004 .469 .842 & 847.468 .098 .541 & 950.695 .696 .580 \\
\hline Energia & 3.905 .492 .856 & 396.051 .933 & 470.954 .353 & 427.606 .721 & 517.839 .988 & 499.957 .271 & 809.965 .950 & 627.311 .652 & 569.705 .003 & 732.944 .602 & 819.856 .852 \\
\hline Essencial a Justiça & 1.356 .059 .636 & 2.126.077.659 & 2.330 .828 .210 & 2.649.535.087 & 3.242 .022 .636 & 3.944 .833 .498 & 4.994.721.417 & 4.710 .937 .831 & 5.010 .560 .916 & 3.593 .752 .478 & 4.229 .139 .522 \\
\hline Gestão Ambiental & 947.749 .417 & 1.193 .443 .083 & 1.992 .004 .466 & 1.497 .923 .121 & 3.145 .948 .115 & 3.639 .079 .446 & 3.697 .451 .936 & 3.550 .299 .963 & 3.574 .140 .034 & 5.355 .453 .301 & 3.580 .612 .382 \\
\hline Habitação & 122.255 .251 & 489.399 .562 & 569.926 .911 & 1.166 .966 .884 & 600.206 .041 & 1.044 .746 .401 & 1.010 .904 .881 & 175.457 .223 & 508.059 .854 & 565.275 .830 & 11.490 .066 \\
\hline Industria & 439.331 .015 & 1.548 .519 .107 & 1.494 .755 .484 & 2.018 .558 .614 & 2.758 .165 .302 & 2.221 .779 .591 & 1.601 .644 .758 & 1.706 .631 .866 & 1.717 .950 .319 & 2.022 .210 .036 & 1.935 .932 .664 \\
\hline Judiciária & 8.359 .812 .944 & 10.530 .935 .648 & 10.674 .598 .981 & 12.799 .794 .905 & 14.071 .241 .532 & 16.500 .680 .475 & 20.463 .605 .786 & 19.765.321.812 & 19.860 .906 .264 & 21.602 .141 .760 & 24.066 .103 .759 \\
\hline Legislativa & 3.075 .018 .192 & 3.535 .512 .778 & 3.806 .780 .934 & 4.191 .712 .137 & 4.362.697.457 & 4.687.235.982 & 5.163 .880 .131 & 4.977.656.651 & 5.297 .861 .717 & 5.304 .632 .408 & 6.168 .198 .115 \\
\hline Organização Agraria & 1.429 .517 .261 & 2.617.626.861 & 3.583 .195 .450 & 4.189 .314 .851 & 4.781 .432 .108 & 4.444.012.106 & 4.844 .686 .080 & 4.184.233.287 & 4.151 .019 .438 & 5.745 .314 .899 & 2.718 .861 .163 \\
\hline Previdência Social & 145.477 .548 .884 & 165.509 .439 .470 & 188.505.524.820 & 212.490 .364 .794 & 233.879 .744 .070 & 258.099 .645 .454 & 291.079 .255 .477 & 325.802 .715 .178 & 359.255 .681 .432 & 399.281 .789 .947 & 444.453 .737 .031 \\
\hline Relações Exteriores & 1.164.074.395 & 1.311 .767 .179 & 1.528 .533 .635 & 1.343.019.694 & 1.413 .153 .108 & 1.841 .962 .679 & 1.548 .807 .996 & 1.790 .872 .365 & 1.797.216.219 & 2.158 .859 .686 & 2.223 .138 .029 \\
\hline Saneamento & 58.683 .470 & 76.549 .869 & 88.265 .176 & 56.178 .402 & 1.555 .051 .857 & 1.781 .446 .363 & 3.018 .961 .464 & 1.745 .333 .451 & 1.653 .032 .041 & 2.653 .720 .247 & 629.464 .341 \\
\hline Saúde & 27.171 .848 .048 & 32.972 .885 .890 & 36.483 .267 .398 & 39.736 .224 .540 & 44.930 .225 .421 & 49.211 .437 .471 & 58.148 .973 .463 & 60.618 .822 .891 & 70.867 .342 .434 & 78.587 .168 .136 & 77.282 .275 .717 \\
\hline Segurança Pública & 2.405 .123 .126 & 2.767 .855 .746 & 3.018 .051 .167 & 3.449 .622 .136 & 4.755 .381 .095 & 5.978 .008 .079 & 7.991.291.125 & 9.006 .915 .156 & 6.950 .532 .144 & 7.878 .515 .353 & 7.236.512.924 \\
\hline Trabalho & 9.494 .835 .293 & 10.706 .740 .025 & 12.716 .914 .013 & 16.417 .403 .505 & 19.596 .794 .928 & 22.529 .791 .807 & 29.300 .856 .977 & 31.235 .629 .397 & 36.225 .377 .158 & 42.283 .482 .279 & 64.458 .088 .324 \\
\hline Transporte & 3.048 .096 .911 & 3.651 .548 .218 & 6.722 .945 .939 & 6.907 .413 .008 & 12.160 .210 .177 & 13.024 .181 .212 & 16.505 .399 .965 & 20.478 .121 .805 & 19.016 .263 .568 & 22.219 .789 .074 & 11.048 .002 .164 \\
\hline Urbanismo & 342.852 .546 & 1.192.707.919 & 2.111 .421 .447 & 2.117 .739 .388 & 4.383.475.820 & 4.298.334.758 & 4.710 .715 .910 & 4.801.231.478 & 4.192 .650 .572 & 4.634 .776 .902 & 1.173 .340 .884 \\
\hline
\end{tabular}

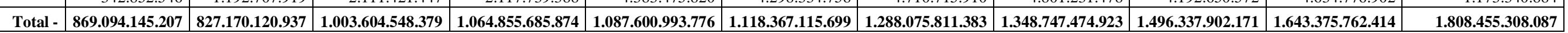
Fontes: Secretaria do Tesouro Nacional e Portal Siga Brasil. 
A expansão significativa da função previdência social é explicada por fatores institucionais, como a ampliação de benefícios introduzida pela CF-88, vinculação de benefícios ao salário mínimo, manutenção da aposentadoria por tempo de serviço com o envelhecimento natural e o aumento da expectativa de vida. Isso exigiu uma mobilização de recursos crescentes para essa função (REZENDE, 2010).

O gasto público médio, no período de 2003 a 2013, com infraestrutura, composto pela soma das funções: habitação, energia, comunicação, saneamento, urbanismo e transporte, totalizou $\mathrm{R} \$ 18.725 .037 .960$, isso equivale a somente $3 \%$ do que o governo gastou em média com a função encargos especial. Porém, mesmo com diversos estudos para o caso brasileiro apontando que aumentando os investimentos nessas funções poderíamos provocar um crescimento do país o governo só investe 3\% em relação ao pagamento de obrigações que não contribuem para a produção de bens ou serviços públicos.

Ao analisarmos cada função que compôs infraestrutura notamos que:

a) no que tange à função habitação houve um aumento expressivo de investimentos nos anos de 2008 e 2009, coincidentemente no ano de 2009 houve o anúncio do programa federal Minha Casa Minha Vida (consiste no financiamento habitacional para famílias de baixa renda);

b) no caso da função energia nota-se que há um grande investimento em 2003, decorrente da crise energética vivida no Brasil no início do século, e nos anos seguintes os valores gastos são superficiais e insuficientes para a expansão da rede e para prevenção de crises, em detrimento do pouco investimento na função energia o país vive, atualmente, uma nova crise energética e hídrica;

c) quanto à função comunicação o valor investido reflete a política, iniciada no fim dos anos 90, de promover a regulação do setor, dado que com as privatizações das ñTelesò os investimentos no setor ficaram a cargo do setor privado;

d) no que tange às funções saneamento e urbanismo nota-se um aumento expressivo do gasto, no caso da função saneamento a partir de 2007 e no 
caso da função urbanismo o valor cresce progressivamente a partir de 2003, muito em função do programa Minha Casa Minha Vida;

e) quanto à função transporte o investimento nessa área foi a que mais se destacou, comparando-se 2003 com 2013 temos um aumento de 68\%, mas foi a partir de 2007 que o cenário mudou, de acordo com Bertussi (2010) diante de um cenário com poucos investimentos em infraestrutura nas últimas décadas e com a necessidade de estimular a participação contínua da iniciativa privada, o governo lançou o Programa de Aceleração do Crescimento (PAC), prevendo investimentos da ordem de 503,9 bilhões de reais para o período 2007-2010. Para o setor de transportes está previsto um total de mais de 55 bilhões de reais $\ddot{i}$ de acordo com a Tabela 02 neste período foram gastos com transportes 62 bilhões, ou seja, um aumento de $11 \%$ sobre o previsto.

O aumento na participação dos gastos em saúde reflete uma tendência de governo de maior atenção para essa área. Segundo Maciel (2013) o setor privado participa significativamente no financiamento da saúde no Brasil, correspondendo a quase $50 \%$ dos recursos alocados. Além disso, ele aloca em saúde recursos próximo à média dos países da OCDE e acima dos países da América Latina, como \% PIB. Assim como no caso da previdência, as despesas com saúde tendem a aumentar em consequência do envelhecimento demográfico. O Brasil já possui gastos próximos à média da OCDE, cuja população é, em média, mais velha. O esforço que o setor público deve empreender é buscar melhorias na gestão de maneira que, mantendo o crescimento do gasto com saúde próximo ao crescimento do PIB, se consiga melhorar os indicadores de atendimento e saúde da população.

A educação é estratégica para o desenvolvimento econômico pelo seu relacionamento direto e indireto com as demais áreas do desenvolvimento, além disso, foi objeto de calorosos debates no último pleito presidencial. No caso das despesas com educação, espera-se que países com perfil demográfico jovem, como o Brasil, tendam a alocar mais recursos no setor do que os demais países (MACIEL, 2013).

Os gastos públicos federais com educação cresceram no período estudado, porém e a partir de 2007, com a implantação do programa de Apoio aos Planos de Reestruturação e Expansão das Universidades Federais (REUNI), que o governo passou 
a dar mais atenção para essa área. Entretanto, segundo Maciel (2013) observa-se que as despesas com Educação em proporção do PIB no Brasil estão 0,7\% abaixo da média dos países da OCDE.

Maciel (2013) concluiu com base no comparativo internacional que a Educação é o único setor, dentre os estudados, que sofre carência alocativa de recursos no Brasil. Esse diagnóstico não excluiu as possibilidades de melhoria nos resultados por meio do avanço na eficiência e na eficácia das políticas públicas voltadas para a educação. Além disso, ficou evidenciado que não há país no mundo que gaste 10\% do PIB em Educação, como o pretendido pelo Plano Nacional de Educação 2011-2020.

Maciel (2013) verificou que o montante de recursos empregado por aluno no Brasil é muito inferior ao dos demais países. Na pré-escola, por exemplo, a média das despesas por aluno da OCDE é quatro vezes maior do que a brasileira. O único nível de ensino próximo à média da OCDE é o ensino superior.

No período de 2003 a 2013 os gastos nominais (valores liquidados) do governo federal em educação superior foram de R \$ 150.734.569.776, o gasto médio ficou na casa dos R \$ 13.703.142.707. Porém, nota-se que o investimento em ensino superior no período de 2003 a 2006 é estável. De 2007 a 2013 o investimento aumenta consideravelmente, esse aumento é explicado pelo Plano de Reestruturação e Expansão das Universidades Federais - REUNI (Decreto 6.096/2007).

Gráfico 01 ï Gastos do Governo Federal com Ensino Superior (2003 a 2013).

$\mathrm{R} \$ 1,00$

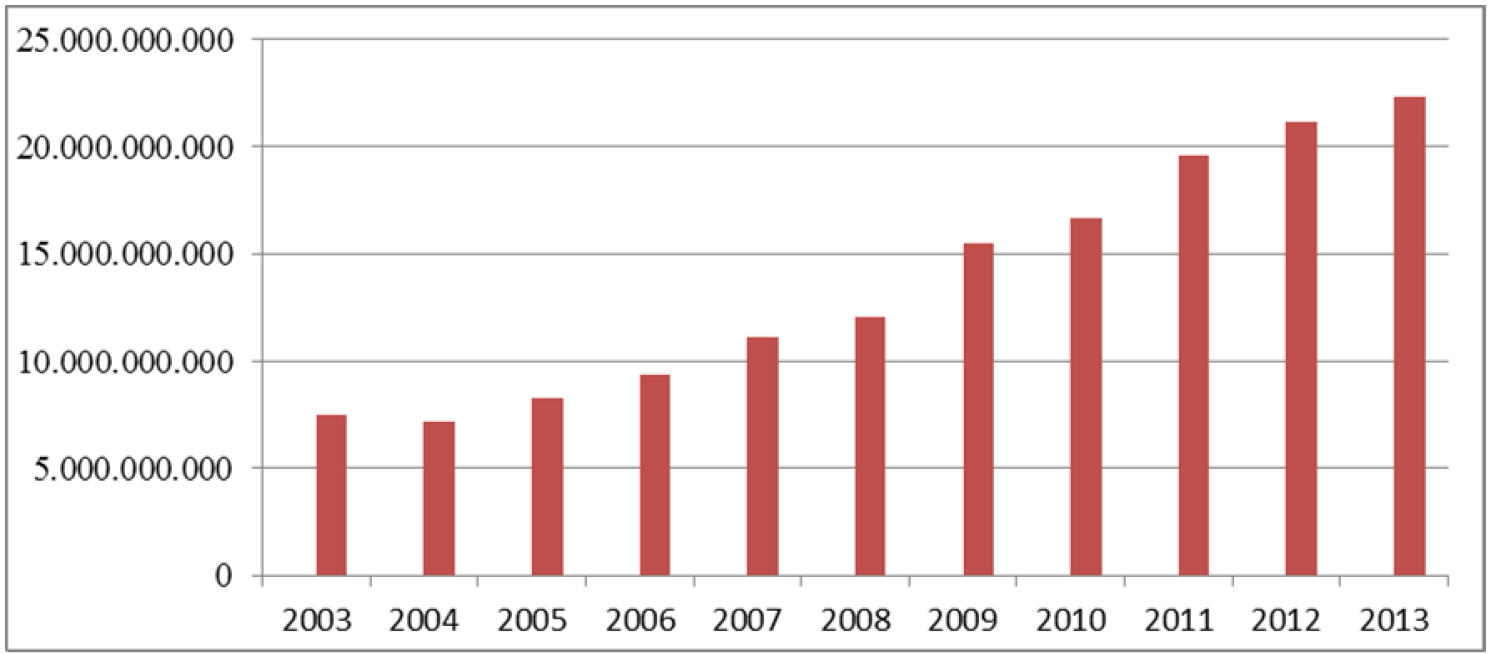

Fonte: Secretaria do Tesouro Nacional

Elaboração Própria 
O Plano de Reestruturação e Expansão das Universidades Federais - REUNI teve como meta elevar a taxa de conclusão média dos cursos de graduação para $90 \%$ e elevar a relação de alunos de graduação em cursos presenciais por professor para 18 ao final de cinco anos (Decreto 6.096/2007).

Para alcançar os objetivos do REUNI foi necessário aumentar os gastos públicos com educação superior no tocante a obras, e readequação de infraestrutura, equipamentos, contratação de pessoal e expansão dos contratos de custeio das Universidades Federais, porém o próprio Decreto que institui o programa limita o aporte de recursos para financiamento do custeio e da contratação de pessoal a $20 \%$ dos valores em 2007 e por somente cinco anos.

Segundo Oliveira, 2013, a significativa expansão física das Universidades promovida pelo REUNI- causaria um possível impacto negativo na capacidade econômica dessas instituições no futuro. Dado que, um maior número de imóveis promove uma ampliação nas despesas de custeio, com a limitação temporal e percentual imposta pelo Decreto que regulamenta a matéria essa ampliação do custeio estaria comprometida e as metas impostas pelo programa poderiam ser prejudicadas. 


\section{METODOLOGIA}

Apresentam-se neste capítulo o tipo de pesquisa, a caracterização do lócus de estudo, os instrumentos de pesquisa, a descrição dos procedimentos de coleta e de análise de dados empregados.

No tocante ao ñipoò essa pesquisa é exploratória, uma vez que proporciona ao leitor maior proximidade com o objeto geral com vistas a torná-lo explicito. Essa pesquisa é também explicativa, dado que tenta explicar os fatores que determinaram ou contribuíram para o aumento do gasto público no lócus de pesquisa.

O campo de estudo abordado é o das Finanças Públicas, especificamente a Qualidade do Gasto Público, esta pesquisa é reforçada por estudos recentes nessa área que procuram explicar quais componentes do gasto público contribuem para o crescimento econômico do País.

Além disso, faz $\ddot{i}$ se necessário compreender como a evolução dos gastos públicos afetou a Educação no decorrer do período estudado, delimitou-se o campo de pesquisa no ensino superior, nas Universidades Federais e com foco na Universidade de Brasília.

Optou-se pelo período de 2003 a 2013 por se tratar do período que o Governo Federal foi presidido unicamente pelo representante eleito do Partido dos Trabalhadores, ou seja, não há nesse período uma ruptura na política econômica e social que afete a análise e interpretação dos dados obtidos.

Os instrumentos utilizados foram: pesquisas bibliográficas, estudos de caso, artigos científicos, teses, dissertações, leis e coleta de dados referentes aos gastos públicos realizados pelo Governo Federal e pelas Universidades Federais. A coleta dos dados foi feita através de pesquisas no SIAFI, Siga Brasil e no sítio da STN. 


\section{DESCRIÇÃO E ANÁLISE DOS DADOS}

A Fundação Universidade de Brasília (UnB), inaugurada em 21 de abril de 1962, segundo o Relatório de Gestão (2013) possui 4916 servidores, entre docentes e técnicos administrativos, e 40465 alunos regulares distribuídos nos cursos de graduação e pósgraduação. Constituída por institutos, faculdades e centros de pesquisa especializados oferece 101 cursos de graduação, 146 cursos de pós-graduação stricto sensu e 27 especializações lato sensu. Os cursos estão divididos em cinco campi espalhados no Distrito Federal e Goiás: Darcy Ribeiro (Plano Piloto), Planaltina, Ceilândia, Alto Paraíso (GO) e Gama. Os órgãos de apoio incluem o Hospital Universitário, a Biblioteca Central, o Hospital Veterinário e a Fazenda Água Limpa.

A tabela 03 foi elaborada a partir de dados coletados no site Siga Brasil, os valores apresentados demonstram o crescimento do orçamento aprovado e executado para a Universidade de Brasília no período de 2003 a 2013.

Tabela 03 ï Evolução Orçamentária da UnB (2003 a 2013).

$\mathrm{R} \$ 1,00$

\begin{tabular}{|l|r|r|r|r|r|}
\hline Ano & Dotação Inicial & \multicolumn{1}{c|}{$\begin{array}{c}\text { Crédito } \\
\text { Disponível }\end{array}$} & Empenhado & \multicolumn{1}{l|}{ Liquidado } & \multicolumn{1}{c|}{ Pago } \\
\hline 2003 & 389.626 .307 & 465.673 .029 & 452.563 .920 & 448.180 .475 & 430.699 .223 \\
2004 & 427.668 .194 & 566.957 .074 & 526.682 .770 & 506.312 .773 & 503.009 .149 \\
2005 & 521.371 .068 & 664.023 .179 & 609.924 .071 & 548.256 .574 & 537.594 .193 \\
2006 & 582.841 .578 & 764.976 .168 & 736.575 .177 & 661.990 .377 & 641.653 .176 \\
2007 & 667.256 .541 & 947.731 .648 & 937.689 .986 & 777.933 .519 & 767.709 .391 \\
2008 & 700.575 .088 & 990.185 .827 & 934.469 .219 & 827.179 .402 & 816.127 .619 \\
2009 & 829.519 .114 & 1.220 .744 .528 & 1.160 .330 .429 & 982.404 .403 & 974.673 .396 \\
2010 & 1.022 .782 .821 & 1.403 .679 .016 & 1.342 .181 .720 & 1.183 .814 .566 & 1.171 .162 .900 \\
2011 & 1.230 .105 .377 & 1.530 .542 .614 & 1.429 .948 .612 & 1.278 .382 .605 & 1.271 .694 .567 \\
2012 & 1.389 .551 .543 & 1.756 .287 .931 & 1.522 .055 .957 & 1.394 .094 .682 & 1.388 .303 .116 \\
2013 & 1.360 .785 .678 & 2.102 .382 .459 & 1.953 .366 .778 & 1.727 .953 .716 & 1.714 .297 .314 \\
\hline
\end{tabular}

Fonte: SIAFI

Elaboração Própria. 
A dotação inicial é aquela aprovada na Lei de Orçamento Anual (LOA), o crédito disponível corresponde à soma da dotação inicial, das descentralizações orçamentárias (segundo o glossário da STN são transferências, realizadas entre as unidades: orçamentária ou administrativa, que possibilitam a execução dos créditos orçamentários ou adicionais fora do órgão de origem) e dos créditos suplementares (segundo o glossário da STN são os aumentos de recursos por crédito adicional, para reforçar as dotações que já constam na LOA), os valores empenhados são os atos do Gestor que cria para o Estado obrigação de pagamento pendente ou não de implemento de condição (Art. 58 da Lei 4.320/64), os valores liquidados representam a obrigação efetiva, ou seja, consiste na verificação do direito adquirido pelo credor tendo por base os títulos e documentos comprobatórios do respectivo crédito (Art. 63 da Lei 4.320/64) e a coluna pago representa o desembolso financeiro efetuado pela UnB para quitação de suas obrigações.

O orçamento da UnB aumentou principalmente em função do Reuni (que ampliou a oferta de vagas aos discentes, e consequentemente aumentou as despesas correntes e de capital) e por conta do crescimento do CESPE (órgão vinculado a Universidade especializado na promoção de eventos e seleção de pessoal por meio de concurso público). Entretanto, Santos (2013) afirma que as universidades federais são carentes de políticas de financiamento exclusivas que atendam as demandas dos pilares ensino, pesquisa e extensão, além de necessitarem de recursos para expandirem suas atividades pelo interior do país.

Neste ínterim, além dos recursos disponíveis na LOA para financiar seus gastos a UnB tem à sua disposição outros recursos que podem ser: convênios, termos de execução descentralizada ${ }^{1}$, extensão universitária ${ }^{2}$ e próprios. Essas captações são decorrentes da prestação de serviços nas áreas de: seleção de pessoal por meio de concursos públicos, pesquisa científica, capacitação profissional, escola de línguas, alugueis, cursos de pós-graduação lato sensu e etc.

\footnotetext{
${ }^{1}$ Instrumento por meio do qual é ajustada a descentralização de crédito entre órgãos elou entidades integrantes dos Orçamentos Fiscal e da Seguridade Social da União, para execução de ações de interesse da unidade orçamentária descentralizadora e consecução do objeto previsto no programa de trabalho, respeitada fielmente a classificação funcional programático (Decreto 8.180/2013).

${ }^{2}$ A extensão universitária se desenvolve por meio das unidades acadêmicas e administrativas da UnB, em processos educativos, culturais e científicos, articulados com o ensino e a pesquisa. É por meio da ação extensionista envolvendo professores, estudantes e técnicos que a Universidade interage com a sociedade, em um exercício de contribuição mútua. São projetos e programas contínuos e especiais, cursos e eventos .(UnB, 2015).
} 


\section{Gráfico 02 ï Evolução da Receita Própria ï UnB (2003 a 2013).}

$\mathrm{R} \$ 1,00$

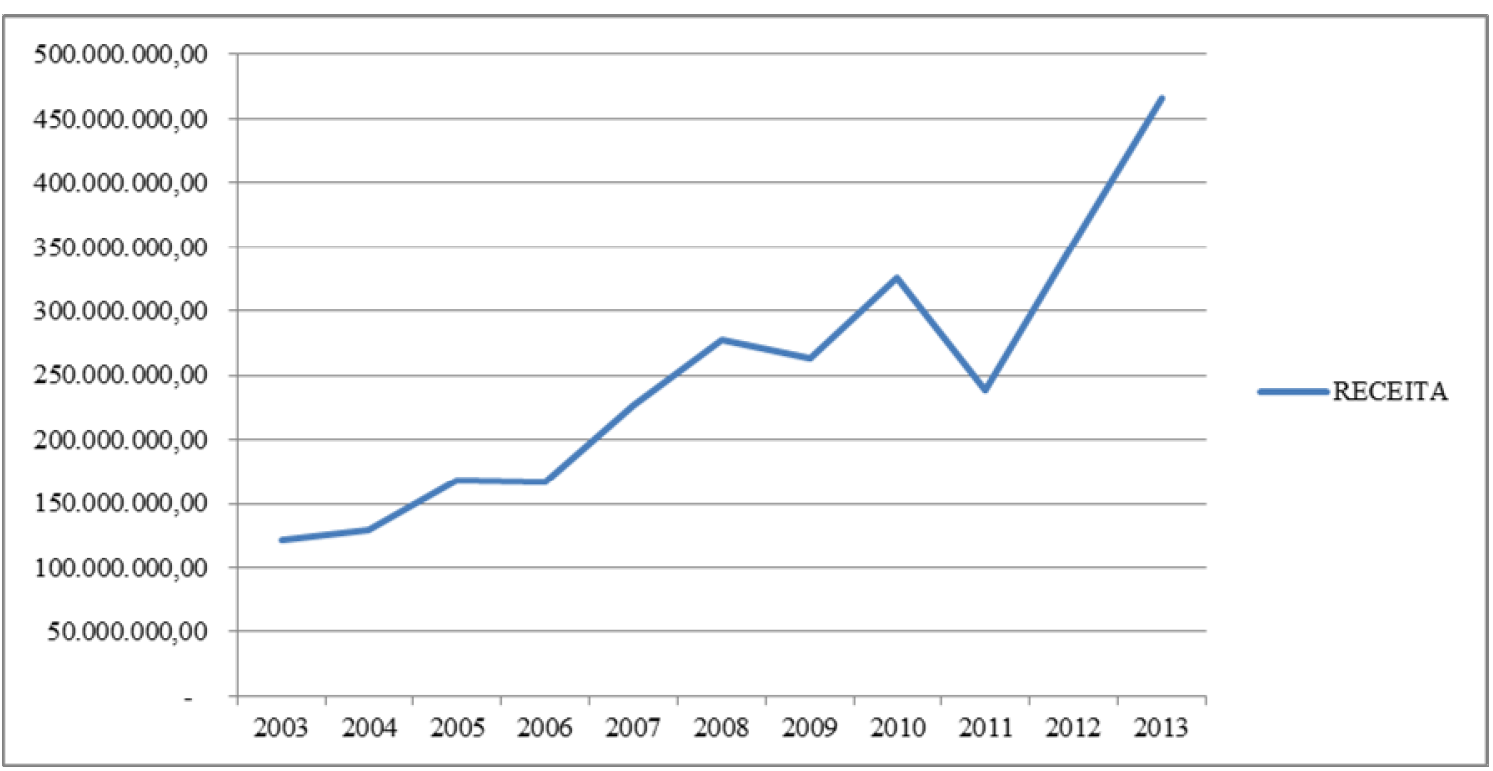

Fonte: SIAFI

Elaboração Própria.

No gráfico 02 verifica-se que a receita da UnB cresceu no período estudado, com exceção dos biênios 2008/2009 e 2010/ 2011. No período 2008/2009 houve a crise institucional da UnB, fato que levou a cassação do Reitor e consequentemente a nomeação de um interventor. No período 2010/2011, já com uma nova equipe eleita democraticamente, houve uma redução na oferta de vagas no serviço público, causando assim uma redução na receita do CESPE e impactando negativamente a evolução da receita na UnB.

$\mathrm{Na}$ média as receitas próprias corresponderam no período estudado, 2003 a 2013, a 31\% da dotação inicial disponível, no que tange a sua importância elas se mantiveram estáveis ao longo do período. Nos anos de 2003 a 2007 esses percentuais variaram de 29\% a 34\%, ou seja, manteve-se estável. Em 2008 houve um aumento significativo elevando essa relação percentual para 40\%. Nos anos de 2009 e 2010 essa relação ficou na casa dos 33\% e 32\% respectivamente. O pior ano foi o de 2011 (19\%) a queda nesse ano foi provocada pela escassez de concursos públicos no país. Em 2012 e 2013 inicia-se um processo de melhoria na relação receita própria x dotação inicial, pois temos em 2012 um percentual de $25 \%$ e em 2013 de $34 \%$. 
Gráfico 03 ï Receita por Departamentos ï UnB (2003 a 2013).

$\mathrm{R} \$ 1,00$

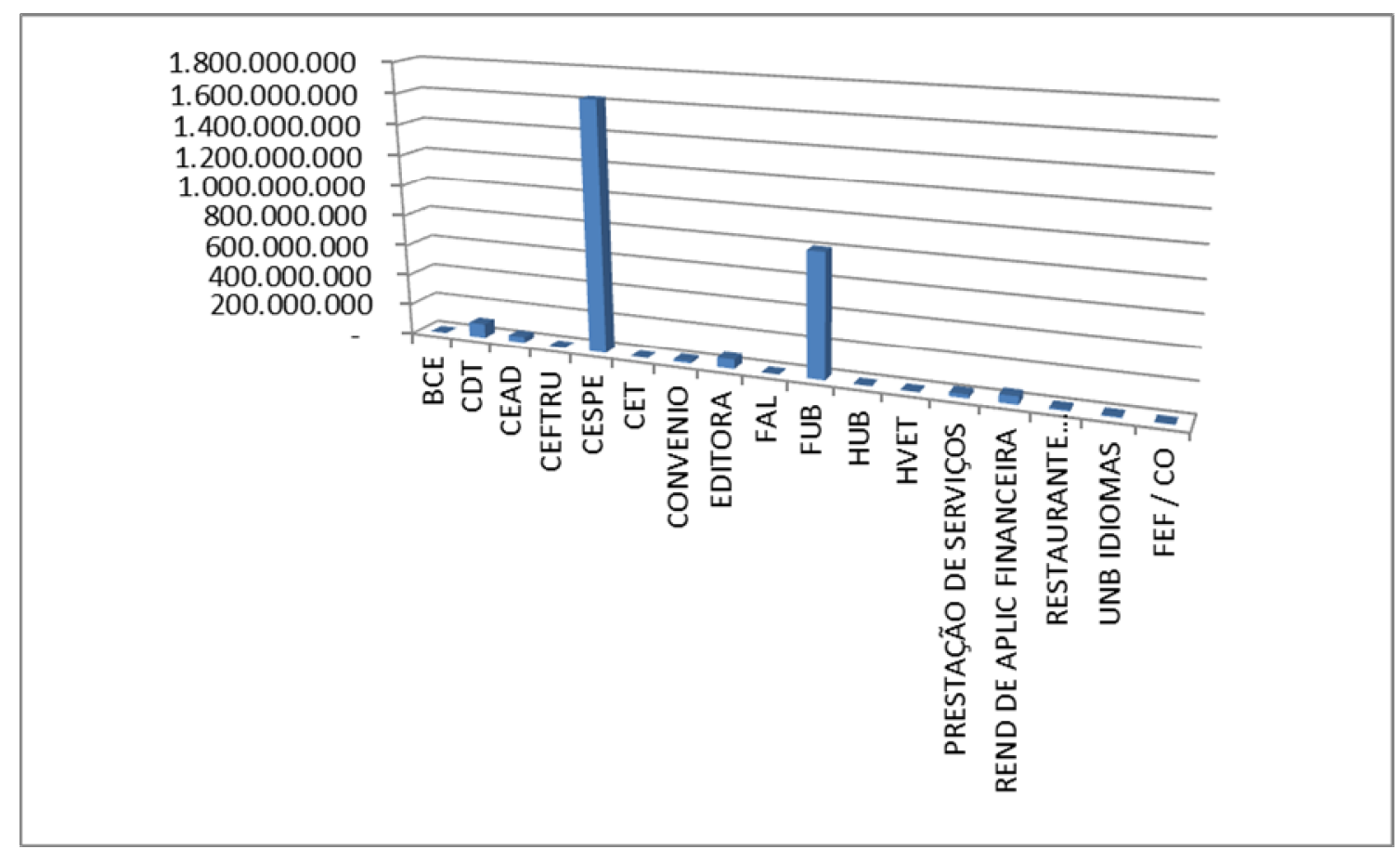

Fonte: SIAFI

Elaboração Própria.

O gráfico 03 demonstra a capacidade de captação de recursos no período estudado (2003 a 2013) por departamento da Universidade de Brasília (BCE ï Biblioteca Central, CDT ï Centro de Desenvolvimento Tecnológico, CEAD ï Centro de Ensino a Distância, CEFTRU ï Centro de Formação de Recursos Humanos em Transportes, CESPE ï Centro de Seleção e de Promoção de Eventos, CET ï Centro de Excelência em Turismo, Convênio ï recursos arrecadados por meio de convênio, Editora ï Editora da Universidade de Brasília, FAL ï Fazenda Água Limpa, FUB ï Fundação Universidade de Brasília, HUB ï Hospital Universitário de Brasília, HVET ï Hospital Veterinário da Universidade de Brasília e FEF / CO ï Faculdade de Educação Física / Centro Olímpico).

A construção deste gráfico foi elaborada a partir de dados extraídos do SIAFI, o critério utilizado foi o da receita efetivamente arrecadada (regime de caixa). Observa-se que as unidades descentralizadas: CDT, Editora e CESPE são as campeãs em arrecadação de recursos próprios. 
O CDT arrecada recursos a partir de quatro eixos de atuação: a) o desenvolvimento empresarial compreende os programas Multincubadora de Empresas e o Hotel de Projetos; b) um deles é voltado para o ensino, pesquisa e difusão do empreendedorismo que compreende o programa Empresa Júnior e a Escola de Empreendedores; c) o eixo transferência de tecnologia compreende a proteção dos resultados das pesquisas realizadas na $\mathrm{UnB}$, além disso, promove a transferência do conhecimento à sociedade por meio de produtos tecnológicos; e d) e a gestão da cooperação institucional que possibilita o desenvolvimento de produtos e serviços direcionados ao ensino, inovação, desenvolvimento de tecnologias e na difusão do empreendedorismo, que são realizados através de parcerias, acordos e protocolos de colaboração com diversas instituições públicas e privadas, nacionais e internacionais.

A Editora arrecada recursos, atualmente, através da edição e comercialização de livros. O CESPE arrecada recursos através da realização de concursos públicos em todas as esferas de governo e poderes.

A FUB arrecada recursos através da cobrança de: mensalidade dos cursos de pós-graduação, alugueis de imóveis comerciais e residenciais, taxas diversas (expedição de diplomas, $2^{\circ}$ via de documentos, etc) e por meio dos custos indiretos cobrados dos projetos de pesquisa (por utilizarem a estrutura da universidade). Outras unidades que captam recursos, mas que a utilização depende da FUB são: BCE, FEF, Restaurante, HVET, FAL.

Os Centros de Pesquisa, vinculados à FUB, arrecadam recursos, porém, a utilização destes recursos deve ser no objeto pactuado do plano de trabalho firmado entre o Centro e o Contratante, ou seja, contratos, convênios, termos de execução descentralizadas, são as unidades: CEAD, CEFTRU, CET, Convênios diversos e outros centros de menor capacidade arrecadadora.

O gráfico 04 reforça a capacidade que o CESPE tem de arrecadação de recursos, dado que no período estudado este centro arrecadou $\mathrm{R} \$ 1,6$ bilhões. 
Gráfico 04 ï Receita por Unidade ï UnB (2003 a 2013).

$\mathrm{R} \$ 1,00$

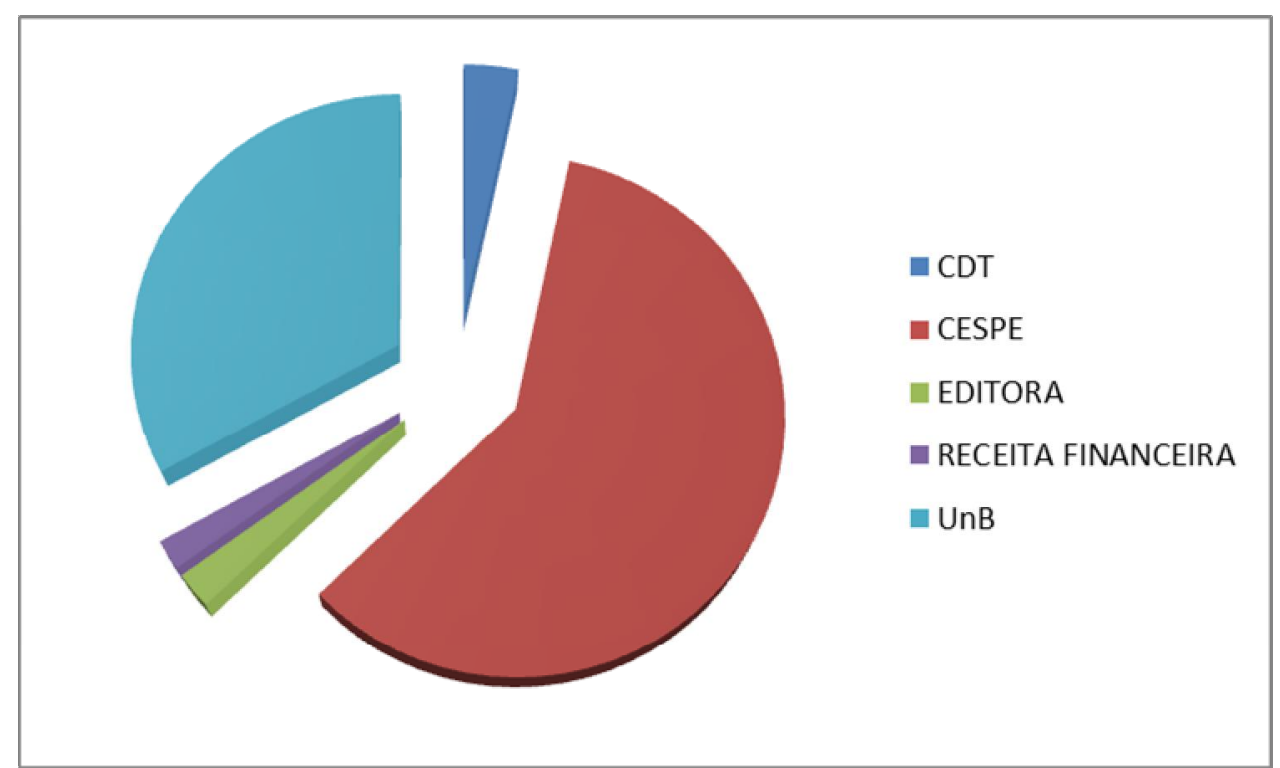

Fonte: SIAFI

Elaboração Própria.

No tocante a despesa o gráfico 05 demonstra a evolução desta na UnB que aumentou 279\% comparando 2003 a 2013 saltando de 448 milhões, em 2003, para 1,7 bilhões em 2013. Esse aumento foi provocado pela expansão da Universidade promovida pelo REUNI, a partir de 2007 e até 2012, gastos com pessoal, manutenção de universidade e investimentos foram os que mais aumentaram no período.

O crescimento de unidades descentralizadas como, HUB, Editora, CESPE e CDT contribuíram também para o crescimento das despesas, principalmente o CESPE com a realização das avaliações: ENEM e SAEB, essas avaliações tem um custo de preparo e aplicação alto comparando-se com concursos normais.

No ENEM aplicado em 2013 houve 7,83 milhões de inscritos, segundo MEC (2013), para mensurar parte do custo o caderno azul de provas contem 32 folhas (INEP, 2013), somente para este caderno houve a impressão de 125,28 milhões de folhas (a prova é impressa em frente e verso), além dos demais cadernos impressos para aplicação das provas. 


\section{Gráfico 05 ï Evolução da Despesa Orçamentária ï UnB (2003 a 2013).}

$\mathrm{R} \$ 1,00$

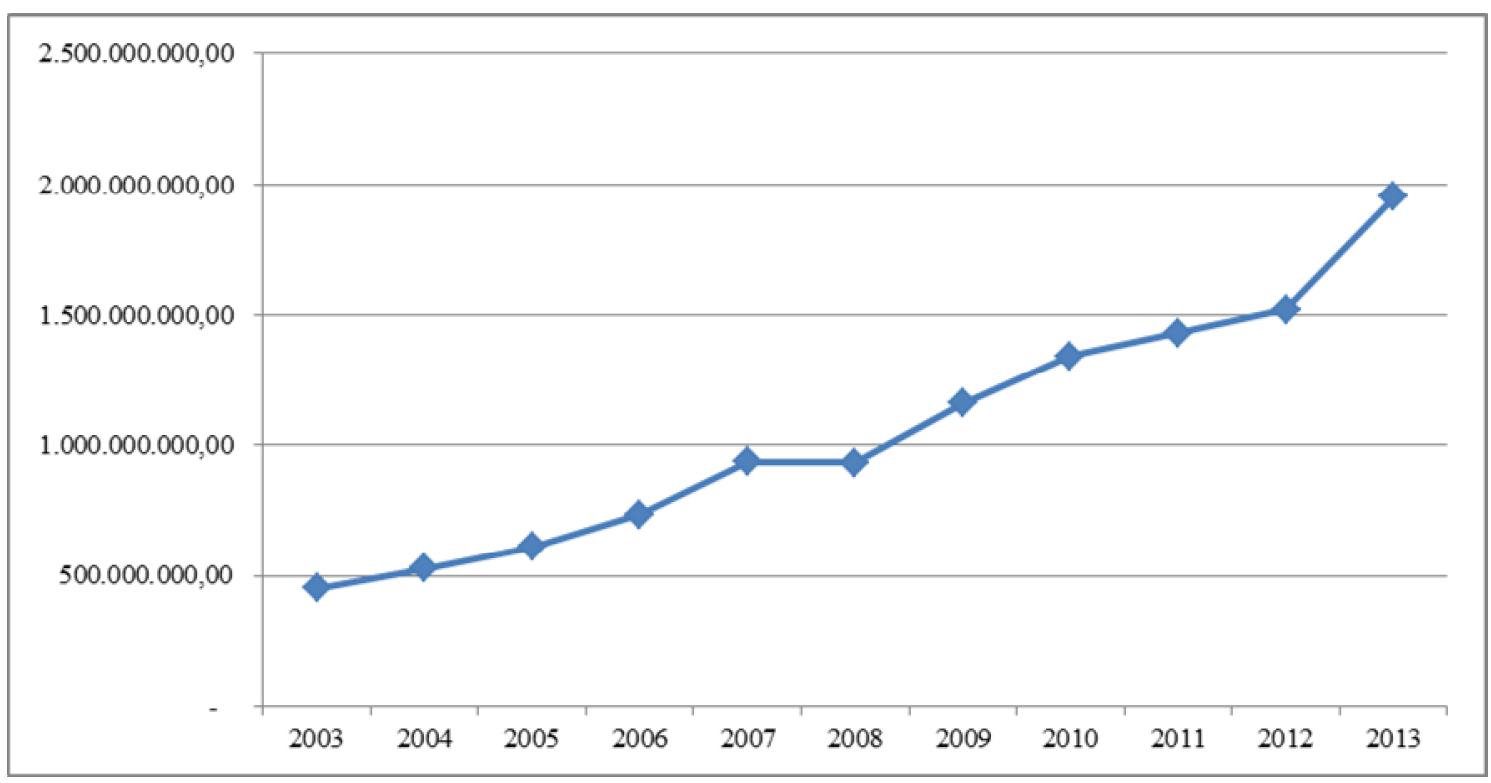

Fonte: SIAFI

Elaboração Própria.

No gráfico 06 notamos que o gasto com pessoal era muito próximo dos gastos com a manutenção da universidade até 2006, isso é um reflexo, segundo Santos (2013), da política estabelecida no governo Fernando Henrique Cardoso (1994-2002), neste período o governo foi incapaz de expandir os gastos com educação em função da política econômica adotada na década de 90 .

Outro fator relevante a época foi a sanção da Lei 11.091/2005 que reestruturou a carreira dos técnicos administrativos em educação no âmbito das instituições federais de ensino superior, com o advento da Lei supra houve elevação nos salários dos servidores que laboravam nas Universidades à época.

A partir de 2007 o REUNI começa a ser operacionalizado e novos concursos para servidores são realizados a fim de suportar a expansão dos cursos de graduação, pós-graduação e aumento da demanda na área administrativa, um aumento no contingente de servidores provocou consequentemente um aumento na despesa de pessoal. 
Gráfico 06 ï Despesas de Pessoal x Despesas de Custeio- UnB (2003 a 2013).

$\mathrm{R} \$ 1,00$

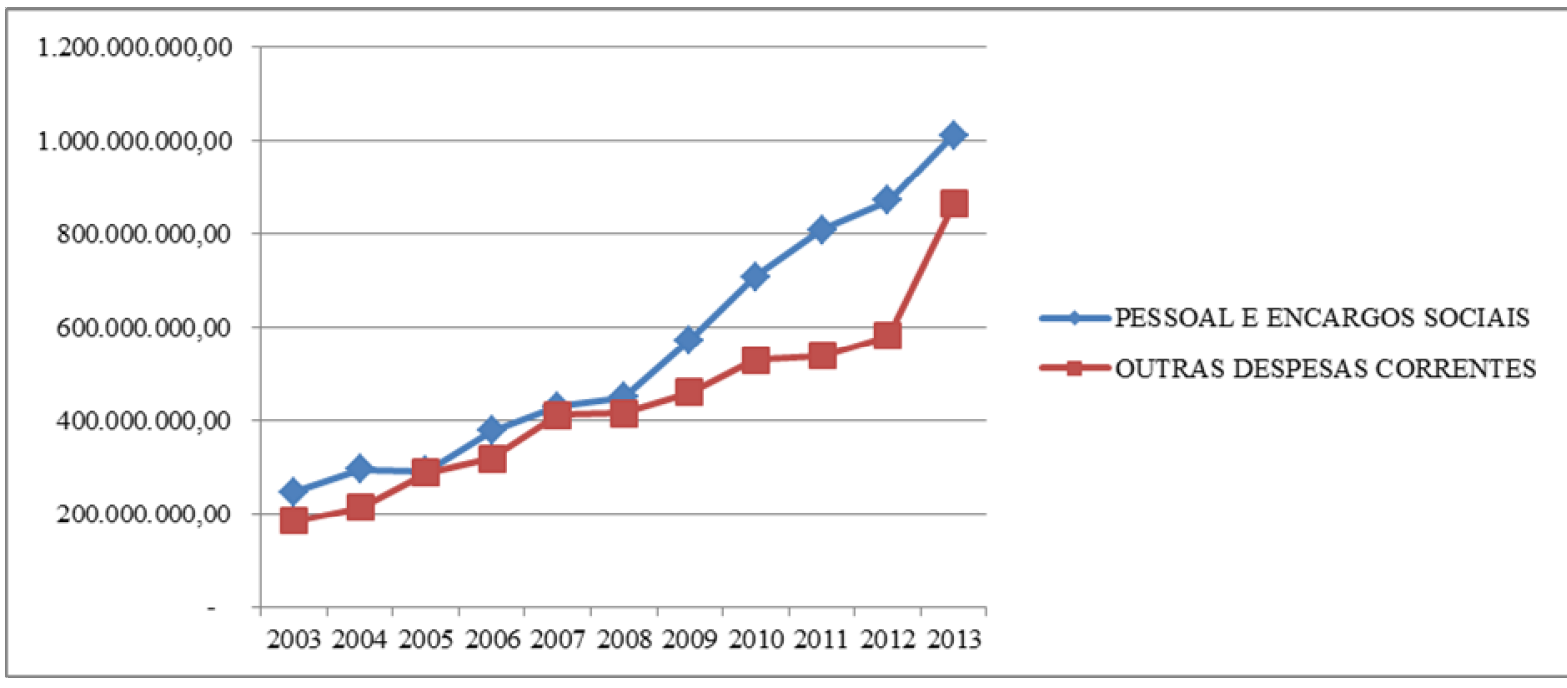

Fonte: SIAFI

Elaboração Própria.

$\mathrm{Na}$ tabela 04 verificamos a evolução e a segregação das outras despesas correntes, que se referem aos gastos destinados à manutenção das atividades da Fundação Universidade de Brasília ou exercidos com essa finalidade, cujos exemplos típicos são: material de consumo, diárias, passagens e despesas de locomoção, serviços de terceiros, locação de mão de obra, arrendamento mercantil, auxílios diversos e etc, executados no período de 2003 a 2013. A linha ñoutras despesas correntesò refere-se ao total gasto com essas despesas no período. 
Tabela 04 ï Discriminação das Outras Despesas Correntes na UnB (2003 a 2013).

$\mathrm{R} \$ 1,00$

\begin{tabular}{|c|c|c|c|c|c|c|c|c|c|c|c|}
\hline DESCRIÇÃO & 2003 & 2004 & 2005 & 2006 & 2007 & 2008 & 2009 & 2010 & 2011 & 2012 & 2013 \\
\hline Outras Despesas Correntes & 184.068 .439 & 212.206 .474 & 288.215 .576 & 317.445 .907 & 411.089 .497 & 414.250 .800 & 459.713 .748 & 529.339 .056 & 539.117 .435 & 581.313 .648 & 864.118 .036 \\
\hline Contratação por Tempo Determinado & & & 1.848 .986 & 2.043 .522 & 2.814 .700 & 3.004 .035 & 3.233 .179 & 3.729 .412 & 4.689 .096 & 4.463 .826 & 526.195 \\
\hline Outros Benefícios Assistenciais & 713.732 & 847.231 & 978.892 & 636.658 & 660.859 & 474.256 & 507.694 & 665.917 & 722.970 & 733.843 & 1.093 .516 \\
\hline Diárias & 1.021 .065 & 1.825 .989 & 2.895 .338 & 3.378 .617 & 5.391 .480 & 3.880 .962 & 4.545 .845 & 6.579 .643 & 4.672 .485 & 3.772 .269 & 4.499 .181 \\
\hline Auxílio Financeiro a Estudante & 11.233 .479 & 13.628 .656 & 15.193 .825 & 17.237 .350 & 19.605 .662 & 19.563 .873 & 20.146 .046 & 15.831 .777 & 21.650 .665 & 27.317 .642 & 32.567 .312 \\
\hline Auxílio Financeiro a Pesquisador & 191.187 & 1.375 .371 & 3.262 .134 & 3.715 .968 & 6.723 .721 & 9.935 .790 & 13.880 .757 & 25.230 .040 & 19.578 .360 & 28.595 .435 & 42.141 .442 \\
\hline Material de Consumo & 19.663 .438 & 21.052 .969 & 24.690 .626 & 24.300 .128 & 25.083 .621 & 33.616 .135 & 35.968 .948 & 32.016 .061 & 37.202 .712 & 38.122 .271 & 45.271 .033 \\
\hline Premiações Diversas & & 12.108 & & 18.000 & & & 8.000 & 10.992 & 59.108 & 989.117 & 29.386 \\
\hline Passagens & 8.161 .830 & 8.601 .868 & 8.987 .920 & 8.894 .075 & 14.564 .965 & 19.150 .274 & 13.180 .659 & 21.075 .750 & 12.478 .289 & 13.411 .695 & 21.212 .642 \\
\hline Serviços de Consultoria & 3.988 & & 225.600 & 7.500 & 53.900 & 446.300 & 81.500 & 208.436 & 1.832 .290 & 171.167 & 5.000 \\
\hline Outros Serviços de Pessoa Física & 59.356 .550 & 73.630 .302 & 74.854 .719 & 103.930 .424 & 133.965 .806 & 155.135 .619 & 191.815.236 & 194.290.116 & 196.093.972 & 220.417.977 & 331.771 .201 \\
\hline Locação de Mão de Obra & 3.582 .793 & 4.677 .191 & 2.883 .515 & 17.257 .078 & 20.507 .186 & 25.938 .644 & 24.371 .569 & 69.971 .098 & 84.390 .718 & 74.513 .366 & 123.306 .213 \\
\hline Outros Serviços Pessoa Jurídica & 62.814 .869 & 62.591 .835 & 117.760 .845 & 83.661 .058 & 122.108 .623 & 85.152 .614 & 86.799 .414 & 78.211 .218 & 74.025 .233 & 85.407 .866 & 125.588 .475 \\
\hline Auxílio Alimentação & 4.673 .330 & 6.868 .528 & 7.219 .439 & 7.568.505 & 7.332 .690 & 7.289 .391 & 7.763 .158 & 16.803 .356 & 17.330 .098 & 18.406 .248 & 22.691 .889 \\
\hline Obrigações Tributárias & 5.498 .226 & 8.201 .920 & 15.198 .790 & 19.872 .202 & 28.463 .061 & 32.496 .333 & 34.372 .606 & 45.240 .503 & 39.881 .015 & 51.141 .681 & 97.188 .608 \\
\hline Auxílio Transporte & 2.976 .137 & 3.529 .843 & 3.259 .579 & 3.925 .501 & 4.123 .892 & 3.939 .282 & 3.719 .132 & 3.911 .704 & 3.370 .342 & 3.152 .308 & 2.891 .940 \\
\hline Depósitos Compulsórios & & & 6.792 & 15.300 & & 57.513 & 2.563 .970 & 2.507 .494 & 6.763 .533 & 35.435 & 382.531 \\
\hline Despesas de Exercícios Anteriores & 4.011 .158 & 5.149 .543 & 4.137 .526 & 7.846 .854 & 13.298 .215 & 10.302 .155 & 12.161 .790 & 7.319 .453 & 7.573 .406 & 3.633 .444 & 4.643 .462 \\
\hline $\begin{array}{l}\text { Indenizações } \\
\text { Instituições Privadas sem fins }\end{array}$ & 166.657 & 213.120 & 165.077 & 215.340 & 789.924 & 2.549 .090 & 4.531 .052 & 5.613 .742 & 6.675 .060 & 6.829 .611 & 8.144 .683 \\
\hline Lucrativos & - & - & 4.645 .973 & 12.921 .825 & 5.601 .192 & 1.318 .532 & 63.193 & 122.342 & 128.083 & 198.447 & 163.328 \\
\hline
\end{tabular}

Fonte: SIAFI

Elaboração Própria. 
Passamos a analisar cada item de gasto efetuado em outras despesas correntes:

a. As despesas executadas na rubrica contratação por tempo determinado referem-se, segundo o Manual de Contabilidade Aplicado ao Setor Público (MCASP ï 2014), a contratação de serviços de pessoa física por tempo determinado, com a finalidade de atender uma necessidade temporária e de excepcional interesse público. No caso da UnB essa rubrica é utilizada para custear o pagamento da mão de obra precária que labora na Universidade, notase que há uma queda na despesa no ano de 2013, essa foi provocada pela assinatura, junto ao Ministério Público do Trabalho, de um termo de compromisso com a Universidade de substituir a mão de obra precária por servidores públicos concursados até junho/2015;

b. A rubrica outros benefícios assistenciais referem-se, de acordo com o MCASP (2014), a despesas com benefícios assistenciais tais como: auxílio-funeral, auxílio-creche e auxílio-doença. Nota-se no período de 2003 a 2013 que o valor gasto não sofre variações relevantes;

c. A rubrica diárias se referem aos valores pagos a pessoa física, servidor público ou não, quando há viagens nacionais ou internacionais segundo o MCASP (2014). Durante o período analisado verificou-se que os anos de 2007 e 2010 ganham destaque por conta do volume de recursos dispendidos, em 2007 a Editora da UnB tinha diversos projetos de pesquisa ativos que demandaram um maior número de viagens. Em 2010 76\% do valor gasto com diárias serviram para subsidiar a aplicação de provas ou etapas de concursos públicos pelo país, ou seja, esses recursos foram gastos pelo CESPE no cumprimento de suas obrigações contratuais pactuadas;

d. A despesa Auxílio Financeiro a Estudante refere-se a valores pagos pelo Estado a estudantes carentes com a finalidade de fomentar o desenvolvimento de estudos, pesquisa científica e a permanência dos alunos até a conclusão do ensino superior. Verifica-se que de 2003 a 
2007 os valores pagos evoluem de acordo com a inflação do período, em 2008 e 2009 os valores sofrem um pequeno aumento por conta do REUNI, mas são estáveis e a partir de 2010 com a sanção do Decreto 7.234/2010 (que dispôs sobre o Programa Nacional de Assistência Estudantil-PNAES) os valores ganham incrementos e critérios de distribuição entre os estudantes;

e. A rubrica Auxílio Financeiro a Pesquisadores refere-se a valores pagos pelo Estado a pesquisadores (docentes e discentes) com a finalidade de fomentar o desenvolvimento de estudos e pesquisa científica no país de acordo com MCASP (2014). Nota-se que o valor gasto varia muito no decorrer do período, porém $96 \%$ do total gasto foram obtidos por meio de projetos de pesquisa, convênios e outras avenças contratuais e somente $4 \%$ do total foram recursos concedidos por meio de editais de pesquisa oriundos do Decanato de Pesquisa e Pós Graduação;

f. A rubrica material de consumo, de acordo com MCASP (2014) refere-se a despesas com materiais de uso não duradouro como combustível, material de escritório, material hospitalar etc. Verificouse que de 2003 a 2009 o valor gasto nessa despesa acompanha o crescimento da universidade, a partir de 2011 o valor gasto aumenta em função da responsabilidade pelo preparo e aplicação do ENEM por parte do CESPE;

g. A rubrica premiações diversas refere-se ao pagamento de prêmios diversos, inclusive em dinheiro, pelo órgão segundo o MCASP (2014). O gasto mais significativo ocorreu em 2012 em virtude da realização do Festival Latino-Americano e Africano de Arte e Cultura (FLAAC) promovido e custeado pela UnB naquele ano;

h. A rubrica passagens refere-se ao pagamento de passagens aéreas e terrestres quando há deslocamento nacional ou internacional de pessoa física ou bem segundo o MCASP (2014). Durante o período 
analisado verificou-se que os anos de 2007, 2008 e 2010 ganham destaque por conta do volume de recursos dispendidos, em 2007 a Editora da UnB tinha diversos projetos de pesquisa ativos que demandaram um maior número de viagens. Em 2008 e 2010 os valores gastos subsidiaram a aplicação de provas ou etapas de concursos públicos pelo país, ou seja, esses recursos foram gastos pelo CESPE no cumprimento de suas obrigações contratuais pactuadas;

i. A rubrica serviços de consultoria representa os valores pagos decorrentes de contratos de consultorias técnicas e auditorias financeiras ou jurídicas segundo o MCASP (2014). Durante o período estudado o gasto relevante ocorreu em 2011 por conta da contratação de empresa especializada na área tributária que tinha por finalidade a redução de ações tributárias que tramitavam na Receita Federal e na Justiça Federal, porém o contrato foi considerado nulo em 2012 e os valores executados no ano anterior foram anulados (por meio do cancelamento do saldo dos empenhos correspondentes);

j. No tocante a rubrica outros serviços de pessoa física, segundo o MCASP (2014), ela representa os valores pagos diretamente a pessoas físicas que não possuem vínculo empregatício com a administração pública, porém prestam serviços técnicos esporadicamente. A partir de 2007 o volume de captação de recursos de projetos na Editora e na UnB aumentaram consideravelmente até 2008 em contrapartida a contratação de mão de obra se tornou necessária. A partir de 2009 a edição, realização e aplicação do ENEM ficou a cargo do CESPE com isso a contratação de pessoal para trabalhar nas diversas etapas do exame foi necessária, em 2013 o CESPE também editou, realizou e aplicou o SAEB (Sistema de Avaliação do Ensino Básico) com grande impacto nacional. 
k. A rubrica locação de mão de obra, de acordo com o MCASP (2014), representa os valores pagos pela administração pública quando há contratação de mão de obra terceirizada: limpeza, segurança, manutenção, jardinagem e etc. Até 2009 os valores gastos com terceirização na UnB eram compatíveis com sua realidade orçamentária, porém a partir de 2010 diversas contratações emergenciais decorrentes de falências de empresas, ausência pessoal técnico capacitado na UnB para realização das licitações de terceirização e também por conta da expansão desordenada (promovida pelo REUNI) levaram ao aumento substancial dessa despesa.

1. A rubrica outros serviços de pessoa jurídica, segundo o MCASP (2014) se refere aos diversos serviços prestados por pessoas jurídicas, mas que não se enquadram como locação de mão de obra ou aquisição de bens de pequena monta. Em 2007 o volume de captação de recursos oriundos de projetos pela Editora da UnB alavancou a despesa dela para $33 \%$ do total gasto, o CESPE participou com $21 \%$ (com sua atividade de realização de eventos), o HUB e o CDT juntos gastaram 5\% em 2007 e a FUB gastou os 53\% restantes. Salienta-se que o gasto com água, luz e telefone (com exceção para o HUB) é todo centralizado na $\mathrm{UnB}$ os $53 \%$ foram gastos com: $46 \%$ com pagamentos a FUBRA e FINATEC pela gestão de projetos e locação de mão de obra, 16\% com energia elétrica, 6\% com água, 6\% com telefonia, $2 \%$ com insumos para a BCE e $24 \%$ com as demais despesas. Em 2013 o gasto foi elevado por conta da realização, edição e aplicação do ENEM e SAEB pelo CESPE em todo o território brasileiro. 
m. A rubrica auxílio alimentação, de acordo com o MCASP (2014), representa os valores pagos aos servidores públicos efetivos destinados ao custeio parcial de suas despesas alimentares. O valor aumenta significativamente a partir de 2010 por conta do reajuste do valor deste a partir de março de 2010 e por conta do maior número de servidores ativos oriundos do REUNI.

n. A rubrica obrigações tributárias, de acordo com o MCASP (2014) refere se ao recolhimento de tributos pelo órgão público. Nota-se que a partir de 2007 há um crescimento dos valores recolhidos, de 2007 a 2012 esse crescimento é explicado pelo aumento nas contratações de pessoas físicas para trabalhos esporádicos em projetos ou concursos públicos, em 2013 além do custo tributário promovido pela contratação de pessoas físicas a UnB aderiu ao refinanciamento de dívidas tributárias promovido pela Lei 11.941/2009 com esse refinanciamento a UnB pagou em 2013 (a vista) uma dívida tributária com INSS no valor de R $\$ 31$ milhões de reais (obteve um desconto de R 20 milhões com o pagamento à vista).

o. A rubrica auxílio transporte, segundo o MCASP (2014), representa os valores destinados ao custeio parcial de suas despesas com transporte de suas residências para o local de trabalho. Nota-se que o valor gasto é constante durante o período, porém tende a aumentar caso haja mais contratação de servidores.

p. A rubrica depósitos compulsórios, segundo o MCASP (2014), representa os valores de depósitos determinados por lei específica ou determinação judicial. Os valores compreendidos no período 2009 a 2011 são referentes às garantias contratuais exigidas pelo INEP para realização do ENEM e SAEB pelo CESPE, cabe salientar em 2011 houve o depósito das garantias contratuais exigidas para as duas avaliações, nos demais anos somente para o ENEM. 
q. A rubrica despesas de exercício anteriores, segundo o artigo 37 da Lei 4.320/64, representa:

ñAs despesas de exercícios encerrados, para as quais o orçamento respectivo consignava crédito próprio, com saldo suficiente para atendê-las, que não se tenham processado na época própria, bem como os Restos a Pagar com prescrição interrompida e os compromissos reconhecidos após o encerramento do exercício correspondente, poderão ser pagas à conta de dotação específica consignada no orçamento, discriminada por elemento, obedecida, sempre que possivel, a ordem cronológica."

Nota-se que no período compreendido entre 2006 a 2011 os valores aumentam consideravelmente, esse aumento é provocado pela insuficiência orçamentária que o HUB logrou durante esses anos, verificou-se que a maior parte dessas despesas, cerca de $90 \%$, são referentes a material de consumo utilizado pelo hospital (insumos, remédios, materiais de higiene, etc) e os demais $10 \%$ são referentes aos outros serviços de terceiros prestados por pessoas jurídicas também no HUB.

r. A rubrica indenizações, segundo o MCASP (2014), representa os valores pagos a título de indenizações, exclusive as trabalhistas, e restituições, devidas pelos órgãos. A partir de 2007 os valores aumentam consideravelmente, em função dos novos concursados oriundos do REUNI, cerca de 95\% das despesas constantes nessa rubrica são com ressarcimento de assistência médica e odontológica.

s. A rubrica instituições privadas sem fins lucrativos representa os valores pagos às Fundações de Apoio. Nota-se que no período de 2005 a 2008 há um volume de pagamentos expressivos, mas com a falência da FUBRA em 2008 e a consequente crise na relação da UnB com as Fundações de Apoio os valores caem consideravelmente. 
Verificou-se nos parágrafos anteriores como se comportou a despesa corrente na UnB no período de 2003 e 2013, notou-se que os maiores gastos concentraram-se no pagamento de pessoal (seja na locação de mão de obra, seja com pessoa física ou auxílios a docentes e discentes). Veremos adiante o comportamento dos investimentos realizados na universidade neste período.

\section{Gráfico 07 ï Investimentos Realizados na UnB (2003 a 2013).}

$\mathrm{R} \$ 1,00$

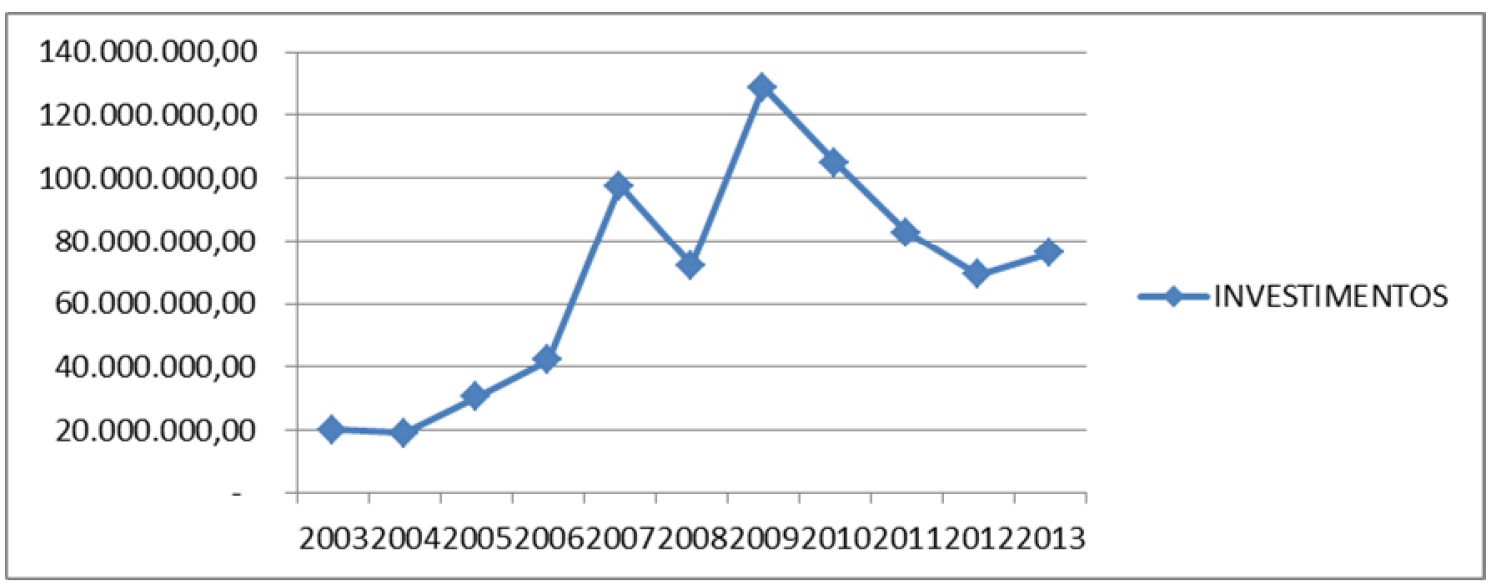

Fonte: SIAFI

Elaboração Própria.

O gráfico 07 representa os investimentos realizados em 2003 a 2013, até 2006 o aumento nos investimentos foi tímido, em 2007 com o advento do REUNI há um aumento significativo, porém, em 2008 houve ñquedaò do Reitor, os investimentos reaquecem em 2009 já com a nova gestão eleita e com mais recursos do REUNI, nos anos seguintes houve a manutenção do REUNI (até 2011) e os investimentos executados em 2012 e 2013 foram realizados com recursos próprios e da LOA.

$\mathrm{Na}$ tabela 05 verificamos a discriminação dos investimentos e inversões financeiras realizados na UnB. No período de 2003 a 2013 os investimentos (total da soma das linhas aplicações diretas mais operações intraorçamentárias) somaram R 742 milhões de reais e foram distribuídos em diversas rubricas dentre elas temos: $46 \%$ em obras e instalações, $49 \%$ aplicados nas aquisições de equipamentos, $5 \%$ em serviços de pessoas jurídicas e $1 \%$ no pagamento de impostos e taxas envolvidos na construção ou importação de equipamentos. As inversões financeiras (composta pela linha aquisições de mercadoria para revenda) $\mathrm{R} \$ 616$ mil e são constituídas principalmente de mercadorias para revenda efetuadas pela Editora da universidade. 
Tabela 05 ï Discriminação Investimentos na UnB (2003 a 2013).

$\mathrm{R} \$ 1,00$

\begin{tabular}{|c|c|c|c|c|c|c|c|c|c|c|c|}
\hline DESCRIÇÃO & 2003 & 2004 & 2005 & 2006 & 2007 & 2008 & 2009 & 2010 & 2011 & 2012 & 2013 \\
\hline Investimentos & $20.136 .622,67$ & $18.966 .387,38$ & 30.311.446,05 & $42.036 .798,13$ & 97.285.168,11 & 72.043.139,18 & 128.724.922,11 & $104.710 .496,64$ & $82.657 .209,80$ & 69.076.882,93 & 76.071.744,34 \\
\hline Transferências a Municípios & - & & & - & - & $1.500 .000,00$ & - & & & - & - \\
\hline Obras e Instalações & & & & - & - & $1.200 .000,00$ & - & - & - & - & \\
\hline Equipamentos e Material Permanente & - & & & - & - & $300.000,00$ & - & & - & - & \\
\hline Aplicações Diretas & $20.136 .622,67$ & $18.966 .387,38$ & $29.559 .446,05$ & $41.768 .024,59$ & 95.443.006,99 & $70.028 .293,08$ & $128.159 .886,67$ & $103.984 .249,26$ & 81.275.431,77 & $68.664 .233,05$ & 76.071.744,34 \\
\hline Diárias & - & & - & - & - & - & - & $18.201,12$ & - & - & \\
\hline Auxílio Financeiro e Estudantes & - & & - & - & - & - & - & & - & - & $96.000,00$ \\
\hline Auxílio Financeiro a Pesquisadores & - & & - & - & - & - & - & $60.000,00$ & - & - & $72.000,00$ \\
\hline Passagens & - & - & - & - & - & - & - & $25.857,48$ & - & - & - \\
\hline Outros Serviços Terceiros ï Pessoa Jurídica & $7.387 .500,00$ & $1.000 .000,00$ & & $9.000 .800,00$ & $14.065 .953,96$ & $62.589,37$ & & $17.979,60$ & $1.078 .604,86$ & $833.894,52$ & $550.050,54$ \\
\hline Obras e Instalações & $2.464 .607,27$ & $4.679 .033,64$ & $18.449 .457,50$ & $23.251 .633,20$ & $51.052 .375,75$ & $43.818 .036,32$ & $54.110 .616,73$ & $59.058 .728,05$ & $40.199 .010,56$ & $20.266 .459,25$ & $21.472 .383,41$ \\
\hline Equipamentos e Material Permanente & $10.284 .015,50$ & $12.659 .093,24$ & $11.109 .988,55$ & $9.515 .591,39$ & $30.324 .677,28$ & $26.143 .007,39$ & $74.049 .269,94$ & $44.730 .750,01$ & $39.997 .816,35$ & $47.563 .879,28$ & $53.880 .401,39$ \\
\hline Despesas de Exercícios Anteriores & 499,90 & $628.260,50$ & - & - & - & $4.660,00$ & - & $72.733,00$ & - & - & 909,00 \\
\hline Operações Intraorçamentárias & - & - & - & - & $301.486,12$ & $514.846,10$ & $565.035,44$ & $726.247,38$ & $1.381 .778,03$ & $412.649,88$ & - \\
\hline Obrigações Tributárias & - & & & - & $301.486,12$ & $514.846,10$ & $565.035,44$ & $726.247,38$ & $1.381 .778,03$ & $412.649,88$ & - \\
\hline Inversões Financeiras & $75.851,64$ & $50.000,00$ & $80.000,00$ & $130.223,00$ & $130.000,00$ & $150.000,00$ & - & - & - & - & - \\
\hline Aquisição de Bens para Revenda & $75.851,64$ & $50.000,00$ & $80.000,00$ & $130.223,00$ & $130.000,00$ & $150.000,00$ & - & - & - & - & - \\
\hline
\end{tabular}

Fonte: SIAFI

Elaboração Própria. 
Analisaremos cada item de gasto efetuado em investimentos:

a. Os gastos executados na rubrica transferências a municípios, segundo o MCASP (2014), referem-se aos recursos transferidos da União ou Estados para os Munícipios. Em 2008 a UnB recebeu uma emenda parlamentar no valor de $\mathrm{R} \$ 1,5$ milhões, esse recurso foi transferido por meio de convênio para o município de Alto Paraíso (GO) e utilizado para a construção do Campus Alto Paraíso.

b. Os gastos efetuados em 2010 e 2013 com diárias, auxílios a estudantes e pesquisadores e passagens são fruto de um projeto de pesquisa da UnB com o Ministério dos Transportes financiados com recursos do PAC (Programa de Aceleração do Crescimento). De acordo com a legislação que regulamenta o PAC os recursos destinados a esse fim devem ser contabilizados como investimentos e após a conclusão da pesquisa devem ser incorporados ao patrimônio da entidade (neste caso específico o próprio contratante).

c. A rubrica outros serviços de terceiros pessoa jurídica já foi explicada anteriormente, em 2003 os gastos executados foram com a fundação de apoio FUBRA para construção do Instituto da Criança e do Adolescente, em 2004 os gastos executados também foram direcionados a FUBRA para execução de projetos diversos, em 2006 os valores também foram executados com fundações de apoio em projetos diversos destacou-se nesse período o envio de $86 \%$ dos recursos para a FINATEC com a finalidade de ampliar o campus UnB, em 2007 esses valores também foram executados com fundações de apoio destacou-se nesse período o envio de $67 \%$ dos recursos a FUBRA e $33 \%$ para a FINATEC com a finalidade de realizarem obras de ampliação e modernização do campus UnB e nos demais anos não houve repasses a fundações de apoio nessa rubrica os gastos efetuados foram: importações diversas, compras de licenças de softwares e outros serviços de pequena monta. 
d. A rubrica obras e instalações, segundo MCASP (2014), referem-se aos gastos efetuados com estudos e projetos, início, prosseguimento e conclusão de obras, além de outras despesas que possam agregar valor a obra. No período compreendido de 2007 a 2011 os valores foram alavancados em função do Programa Reuni que promoveu a realização de diversas obras entre elas temos a construção dos campi: Ceilândia, Gama, Planaltina; os prédios: da FACE, IPOL, IREL, BAES, BSA SUL, IB, reforma da casa do estudante universitário e etc.

e. A rubrica equipamentos e material permanente, segundo o MCASP (2014), referem se aos gastos efetuados com compras de equipamentos diversos tipo: mesas, cadeiras, computadores, veículos, equipamentos hospitalares e etc. Os dispêndios efetuados nessa rubrica sempre foram altos, mas foi a partir de 2007 com o REUNI é que os gastos foram alavancados, além disso, com tantos prédios sendo construídos e com a expansão da UnB para outras cidades foi necessária a compra de novos equipamentos.

f. A rubrica obrigações tributárias já foi explicada anteriormente, porém quando se trata dela aplicada aos investimentos notamos que a execução ocorreu no período de 2007 a 2012 e é nesse período que o Reuni injetou recursos financeiros na Universidade para alavancar sua expansão, os gastos efetuados nesse período são decorrentes de taxas e impostos para construção de obras ou compra de equipamentos.

g. A rubrica aquisição de bens para revenda, segundo o MCASP (2014), refere-se às aquisições de produtos destinados à revenda, no caso da UnB essas aquisições ocorreram no período de 2003 a 2008 e foram feitas pela Editora da UnB que adquiria produtos diversos para revenda nas livrarias, com a crise da Editora em 2008 essa política de aquisições foi revista e extinta. 
Após análise dos dados comprovou-se que houve um aumento considerável das receitas próprias, no período de 2003 a 2013, esse aumento é explicado pelo elevado volume arrecadado no CESPE e pela elevação na arrecadação dos cursos de pósgraduação na Universidade.

Cabe salientar que o aumento verificado nas receitas próprias é suficiente para cobrir o aumento nas outras despesas correntes, dado que os recursos disponíveis para pagamento de servidores é uma despesa constitucional obrigatória, porém, aplicar recursos próprios no pagamento de outras despesas correntes como: água, luz, telefone e terceirização demonstra a falta de planejamento e organização. Esses recursos poderiam ser aplicados na construção e reforma de laboratórios de pesquisa, reforma de salas de aulas, expansão do prédio da reitoria, estímulo à pesquisa por meio de editais e etc.

Para incrementar as receitas próprias, no futuro, medidas simples poderiam ser implementadas como: a expansão dos cursos de pós-graduação lato sensu, a revisão dos preços dos aluguéis para que os mesmos reflitam o praticado pelo mercado, a cobrança de taxa que aborde os custos indiretos envolvidos nos projetos de pesquisa e outros.

Notou-se também, após a análise, que as outras despesas correntes aumentaram no período de 2003 a 2013, porém algumas despesas não possuem contrapartida gerada a partir de receitas (exemplo: água, luz, telefone, material de consumo e terceirização).

Nestes casos medidas de restrição são necessárias a fim de adequá-las à realidade orçamentária da UnB, ou seja, promover ações de conscientização quanto ao uso da água, promover campanhas para redução no consumo da energia elétrica e do telefone, revisar todos os contratos de terceirização a fim de adequá-los à disponibilidade orçamentária ofertada pelo Governo Federal e promover campanhas para reduzir o uso dos recursos materiais (papel, toner e etc).

No tocante aos investimentos realizados no período de 2003 a 2013 notou-se que o pico do REUNI ocorreu em 2009, neste ano houve o empenho da maioria das obras realizadas na UnB, de 2010 em diante houve a manutenção das obras construídas e a aquisição de bens móveis e de informática para equipar os novos prédios.

Porém, não houve investimentos na expansão do HUB, na construção de um novo prédio para a Reitoria da universidade e não houve uma reforma no Instituto Central de Ciências. Entretanto, os investimentos realizados proporcionaram aumento no: número de cursos oferecidos, na oferta de vagas para os estudantes da graduação e da pósgraduação a partir de 2010 e no quadro de pessoal ativo da UnB. Esses números podem ser comprovados na Tabela 06 Indicadores de Desempenho da UnB abaixo: 
Tabela 06 Indicadores de Desempenho da UnB (2003-2013)

Em unidades.

\begin{tabular}{|c|c|c|c|c|c|c|c|c|c|c|c|}
\hline & 2003 & 2004 & 2005 & 2006 & 2007 & 2008 & 2009 & 2010 & 2011 & 2012 & 2013 \\
\hline Ingressantes - GRADUAÇÃO & 5.234 & 4.510 & 4.451 & 5.397 & 7.229 & 6.628 & 8.017 & 8.366 & 9.892 & 8.530 & 8.764 \\
\hline Alunos registrados - GRADUAÇÃO & 22.310 & 21.771 & 20.828 & 21.519 & 23.470 & 25.314 & 27.929 & 29.775 & 38.387 & 36.135 & 39.979 \\
\hline $\mathrm{N}^{\circ}$ de Cursos - GRADUAÇÃO & 60 & 60 & 60 & 63 & 71 & 80 & 91 & 103 & 136 & 138 & 161 \\
\hline $\mathrm{N}^{\circ}$ de Cursos noturnos - GRADUAÇÃO & 15 & 15 & 15 & 15 & 15 & 18 & 24 & 31 & 32 & 35 & 35 \\
\hline Total de Cursos - GRADUAÇÃO & 75 & 75 & 75 & 78 & 86 & 98 & 115 & 134 & 168 & 173 & 196 \\
\hline \multicolumn{12}{|l|}{ Número de cursos - PÓS-GRADUAÇ̃̃o } \\
\hline Mestrado & 49 & 56 & 56 & 59 & 64 & 68 & 68 & 73 & 74 & 82 & 85 \\
\hline Doutorado & 29 & 31 & 35 & 39 & 43 & 50 & 53 & 56 & 59 & 64 & 66 \\
\hline \multicolumn{12}{|l|}{ Alunos registrados - PÓS-GRADUAÇÃO } \\
\hline Mestrado & 2.409 & 2.713 & 2.936 & 2.823 & 2.842 & 3.017 & 3.065 & 3.309 & 4.442 & 5.026 & 4.982 \\
\hline Doutorado & 1.013 & 1.282 & 1.425 & 1.537 & 1.629 & 1.795 & 1.941 & 2.174 & 2.668 & 3.047 & 3.165 \\
\hline Residência Médica & 77 & 98 & 106 & 114 & 125 & 133 & 143 & 152 & 297 & 311 & 329 \\
\hline \multicolumn{12}{|l|}{ QUADRO DE PESSOAL } \\
\hline Docentes Ativos & 1.361 & 1.293 & 1.345 & 1.445 & 1.349 & 1.390 & 1.736 & 2.074 & $\mathrm{ND}^{3}$ & 2.485 & 2.364 \\
\hline Técnico-Administrativos Ativos & 2.074 & 2.359 & 2.343 & 2.269 & 2.061 & 2.066 & 2.205 & 2.448 & ND & 2.731 & 2.637 \\
\hline Total de Pessoal Ativo & 3.435 & 3.652 & 3.688 & 3.714 & 3.410 & 3.456 & 3.941 & 4.522 & $\mathrm{ND}$ & 5.216 & 5.001 \\
\hline
\end{tabular}

Fonte: Decanato de Planejamento e Orçamento - UnB

${ }^{3}$ ND ï Não Disponível 
Ao analisar a tabela 06 verifica-se que:

a. Há um aumento de $67 \%$ no número de ingressantes para os cursos de graduação;

b. Há um aumento de $79 \%$ nos alunos matriculados nos cursos de graduação;

c. Houve um aumento de $161 \%$ na oferta de cursos de graduação;

d. Houve também um aumento na oferta dos cursos de mestrado e doutorado;

e. O número de alunos registrados nos cursos de pós-graduação triplicou no período (com exceção para o mestrado que dobrou o quantitativo de alunos registrados);

f. O quadro de pessoal também cresceu, com destaque para a contratação de docentes com um aumento de $74 \%$;

Porém, deve ser avaliado o produto que a UnB disponibiliza para o mercado, ou seja, após a construção de vários campi e o aumento de vagas nos cursos de graduação e pósgraduação deve ser verificado se houve um aumento no número de formandos e isso pode ser visualizado na tabela 07.

Tabela 07 ï Alunos Formados UnB (2003-2013)

Em unidades.

\begin{tabular}{|l|r|r|r|r|r|r|r|r|r|r|r|}
\cline { 2 - 10 } \multicolumn{1}{c|}{} & $\mathbf{2 0 0 3}$ & $\mathbf{2 0 0 4}$ & $\mathbf{2 0 0 5}$ & $\mathbf{2 0 0 6}$ & $\mathbf{2 0 0 7}$ & $\mathbf{2 0 0 8}$ & $\mathbf{2 0 0 9}$ & $\mathbf{2 0 1 0}$ & $\mathbf{2 0 1 1}$ & $\mathbf{2 0 1 2}$ & $\mathbf{2 0 1 3}$ \\
\hline Alunos formados - GRADUAÇÃO & 3.935 & 4.133 & 3.089 & 3.297 & 3.431 & 3.513 & 4.319 & 4.202 & 3.843 & 3.789 & 3.616 \\
Mestrado - Títulos outorgados & 818 & 800 & 877 & 918 & 962 & 1.022 & 975 & 874 & 1.446 & 1.726 & 1.063 \\
Doutorado - Títulos outorgados & 151 & 203 & 207 & 226 & 274 & 318 & 313 & 258 & 469 & 561 & 383 \\
\hline
\end{tabular}

Fonte: Decanato de Planejamento e Orçamento

Nota-se que há uma queda no número de alunos formados na graduação e, mais recentemente, também nos cursos de mestrado e doutorado. Essa queda no número de formandos é explicada pelo grande número de ingressantes em cursos novos que ainda não tiveram tempo suficiente para concluir a graduação, cabe salientar que uma análise no curto prazo perde sua eficácia, porém, deve ser reavaliada daqui a alguns anos. 
Em suma, os investimentos realizados no período de 2003 a 2013 se mostraram de grande valia, pois possibilitaram um aumento na oferta de vagas nos cursos de graduação e pós-graduação, a expansão da universidade em outras cidades do Distrito Federal e a criação de mais cursos de graduação e pós-graduação. Esse conjunto de ações é excepcionalmente assertivo do ponto de vista social, pois possibilitou o aumento da abrangência e o alcance do ensino superior no Brasil e, em especial, na UnB.

Entretanto, o crescimento visto no período demonstrou também a falta de planejamento, e por diversas vezes a improdutividades da gestão, existente na universidade, dado que o crescimento dela provocou um aumento desordenado nas despesas de custeio como água, luz, telefone, locação de mão de obra e etc. Além disso, outros problemas intangíveis foram criados como: redução na oferta de vagas nos estacionamentos, aumento da demanda por copiadoras e lanchonetes nos intervalos das aulas, aumento da poluição sonora nas salas de aula, dificuldade na alocação das salas de aula adequadas ao número de discentes e etc. 


\section{CONCLUSÃO}

O objetivo deste trabalho foi verificar, por meio de um estudo de caso sobre a quantidade e a qualidade do gasto público na $\mathrm{UnB}$, se houve aumento dos gastos públicos com ensino superior no período de 2003 a 2013 e se essa elevação nos gastos proporcionou crescimento físico e um maior acesso a UnB no período proposto.

Verificou-se na literatura que, após vários planos de estabilização econômicos, o Plano Real controlou o processo de aceleração inflacionária e que a LRF se tornou o principal instrumento de controle das finanças públicas brasileiras, além disso, o referencial teórico demonstrou também que no caso dos gastos públicos com educação a relação destes com a taxa de crescimento econômico é positiva.

Os gastos públicos federais com educação cresceram no período estudado, porém e a partir de 2007, com a implantação do REUNI, que o governo passou a dar mais atenção para essa área. No período de 2003 a 2013 os gastos nominais (valores liquidados) do governo federal em educação superior foram de $\mathrm{R} \$ 150.734 .569 .776$, o gasto médio ficou na casa dos $\mathrm{R} \$ 13.703 .142 .707$. Porém, nota-se que o investimento em ensino superior no período de 2003 a 2006 é estável. De 2007 a 2013 o investimento aumenta consideravelmente, esse aumento é fruto do REUNI.

Após a análise dos dados verificou-se que a UnB tem um potencial enorme para arrecadar recursos financeiros (geração de receitas), essa capacidade é comprovada nos seus diversos ramos de atuação: cursos de pós-graduação lato sensu, projetos de pesquisa, prestação de serviços na área de concursos públicos, aluguéis e taxas diversas.

Verificou-se no período estudado que as despesas de custeio (água, luz, telefone, terceirização e etc) cresceram exageradamente e sem o devido controle administrativo, esse aumento pode ser explicado pelo volume de obras concluídas decorrentes da expansão da universidade. 
Notou-se que os investimentos realizados na UnB no período de 2003 a 2013 proporcionaram uma expansão física da universidade a outros centros urbanos, além disso, os investimentos também proporcionaram um aumento na oferta de vagas e nos cursos graduação e da pós-graduação. Porém, há uma queda no número de alunos formados na graduação e, mais recentemente, também nos cursos de mestrado e doutorado. Essa queda é elucidada pelo aumento no número de ingressantes em cursos novos que ainda não tiveram tempo suficiente para concluir a graduação, cabe salientar que uma análise no curto prazo perde sua eficácia, porém, deve ser reavaliada daqui a alguns anos.

Em suma, após análise dos dados verificou-se na UnB, no período de 2003 a 2013, que o Governo Federal aportou mais recursos na universidade e esses recursos proporcionaram o crescimento da UnB visualizado no período, porém esse crescimento tem duas dimensões bem explícitas, umas delas foi o crescimento econômico e social que a universidade obteve e a outra foi causada pela deficiência no planejamento das ações na universidade, pois o crescimento também provocou aumento nas despesas de custeio e criou diversos problemas administrativos / intangíveis.

Proporcionar mais vagas no ensino superior gera externalidades positivas para o país, no caso da UnB a possibilidade de implantação do turno vespertino para os cursos de graduação e pós-graduação e a criação de cursos inteiramente noturnos pode proporcionar um benefício social próximo ao encontrado neste trabalho e ainda manter os níveis das despesas de custeio estáveis, uma vez que não há necessidade de se expandir fisicamente a Universidade para se implantar os turnos vespertinos e inteiramente noturnos pode-se utilizar as unidades construídas existentes para este fim, entretanto a ampliação dos turnos de aulas não afasta os problemas administrativos/intangíveis.

Portanto, a expansão das Instituições Federais de Ensino Superior e, em particular, da UnB observada nos últimos anos é positiva e desejável do ponto de vista social, pois amplia o acesso à universidade e gera impactos significativos na vida particular do indivíduo, bem como na sociedade em geral. Contudo, do ponto de vista estritamente econômico, é preciso cautela na realização das despesas e prioridades na escolha dos investimentos. 


\section{REFERÊNCIAS BIBLIOGRÁFICAS}

ALMEIDA, Paulo Roberto de - A experiência brasileira em planejamento econômico: uma síntese histórica ï 2004. Disponível em< http://www.prALMEIDA.net/05DocsPRA/1277HistorPlanejBrasil.pdf> Acesso em $23 / 07 / 14$

ASSUNÇÃO , Matheus, ñPAEG: O Programa de Ação Econômica do Governo e a Economia Brasileira nos anos 1960ò, Brasília: Faculdade de Economia, Administração e Contabilidade ï FACE da UNB, 2010. Disponível em< http://petecounb.files.wordpress.com/2011/03/programa-de-ac3a7c3a3o-econc3b4mica-dogoverno-e-a-economia-brasileira-nos-anos-1960-matheus-assunc3a7c3a3o.pdf > Acesso em $29 / 07 / 14$

ARRAES, Ronaldo de Albuquerque; TELES, Vladimir Kuhl. Política fiscal e crescimento econômico: aspectos teóricos e evidências empíricas para as regiões brasileiras. Revista Econômica do Nordeste, Fortaleza, v. 32, n. Especial p. 676-690, nov, 2001. Disponível em

http://www.repositorio.ufc.br/bitstream/riufc/2291/1/2001_art_raarraes.pdf> acessos em 30 out. 2014

ASCHAUER, David Alan. Is public expenditure productive? Journal of Monetary Economics, v. 23, p. 177-200, 1989. Disponível em <http://nexus.umn.edu/Courses/Cases/CE5212/F2009/CS5/Case_Study_files/Aschauer_Pr oductive.pdf $>$ acessos em 28 out. 2014

BAER, Werner. A Economia Brasileira: Tradução de Edite Sciulli, 2011 ï São Paulo. $3^{\circ}$ Edição. Nobel. 
BASTIAN, Eduardo F. O PAEG e o plano trienal: uma análise comparativa de suas políticas de estabilização de curto prazo. Estud. Econ., São Paulo , v. 43, n. 1, mar. 2013 . Disponível em <http://www.scielo.br/scielo.php?script=sci_arttext\&pid=S010141612013000100006\&lng=pt\&nrm=iso>. acessos em 13 ago. 2014. http://dx.doi.org/10.1590/S0101-41612013000100006.

BRESSER-PEREIRA, Luiz Carlos. Os dois congelamentos de preços no Brasil, Revista de Economia Política, São Paulo, vol. 8, n 4, outubro-dezembro/1988. Disponível em <http://www.rep.org.br/PDF/32-4.PDF> acesso em 07/09/2014.

BRESSER-PEREIRA, Luiz Carlos. O plano verão e a crise estrutural da economia brasileira. Revista de Economia Política, vol. 9, 1989. . Disponível em <http://www.rep.org.br/pdf/36-10.pdf> acesso em 09/09/2014.

BERTUSSI, Geovana Lorena. Gastos Públicos com Infraestrutura de Transporte e Crescimento Econômico: Uma Análise para os Estados Brasileiros. 2010. Doutorado em Economia do Programa Pós-Graduação em Economia da Universidade de Brasília. Disponível em <http://repositorio.unb.br/bitstream/10482/8518/1/2010_GeovanaLorenaBertussi.pdf > acessos em 30 out. 2014

BIRD, Richard M., The Growth of Government Spending in Canada. Toronto: Canadian Tax Foundation, Canadian Tax Papers n. 51, 1970. Disponível em < http://www.jstor.org/discover/10.2307/824951 ?uid=3737664\&uid=2134\&uid=2\&uid=70\& uid=4\&sid=21104794362377> . acessos em 11 out. 2014

BRASIL. Decreto 6.096, de 24 de abril de 2007. Institui o Programa de Apoio a Planos de Reestruturação e Expansão das Universidades Federais - REUNI. Brasília, 24 de abril 
de 2007. Disponível em < http://www.planalto.gov.br/ccivil_03/_ato20072010/2007/decreto/d6096.htm>. acessos em 05 fev. 2015.

Decreto 8.180, de 30 de dezembro de 2013. Altera o Decreto $\mathrm{n}^{\circ} 6.170$, de 25 de julho de 2007, que dispõe sobre as normas relativas às transferências de recursos da União mediante convênios e contratos de repasse. Brasília, 30 de dezembro de 2013. Disponível em $\quad<\quad$ http://www.planalto.gov.br/ccivil_03/_Ato20112014/2013/Decreto/D8180.htm>. acessos em 18 mai. 2015.

Lei 4.320, de 17 de março de 1964. Estatui Normas Gerais de Direito Financeiro para elaboração e controle dos orçamentos e balanços da União, dos Estados, dos Municípios e do Distrito Federal. Brasília, 17 de março de 1964. Disponível em <http://www.planalto.gov.br/ccivil_03/leis/14320.htm>. acessos em 05 fev. 2015.

Lei Complementar 101, de 04 de maio de 2000, Disponível em< http://www.planalto.gov.br/ccivil_03/leis/lcp/lcp101.htm> acesso em 26/09/2014.

Constituição Federal, de 05 de Outubro de 1988, Disponível em< http://www.planalto.gov.br/ccivil_03/constituicao/ConstituicaoCompilado.htm> acesso em Acesso em 15 jan. 2015.

MinistéRIO DO PlANEJAMENTO E ORÇAMENTO. Portaria 42, de 14 de abril de 1999. Atualiza a discriminação da despesa por funções de que tratam o inciso I do $\S 1$ o do art. 20 e $\S 20$ do art. 8o, ambos da Lei no 4.320, de 17 de março de 1964, estabelece os conceitos de função, subfunção, programa, projeto, atividade, operações especiais, e dá outras providências. Brasília, 14 de abril de 1999. Disponível em <http://www.sepof.pa.gov.br/ppasite/pdf/Portaria_n_42_de_14_de_abril_de_1999_MOG.p df>. acessos em 05 fev. 2015. 
CARVALHO, Carlos Eduardo. As origens e a gênese do Plano Collor. Nova econ., Belo Horizonte , v. 16, n. 1, abr. 2006 . Disponível em $<$ http://www.scielo.br/scielo.php?script=sci_arttext\&pid=S010363512006000100003\&lng=pt\&nrm=iso>. acessos em 15 set. 2014. http://dx.doi.org/10.1590/S0103-63512006000100003.

CÂNDIDO JÚNIOR, José Oswaldo. Os Gastos Públicos no Brasil são Produtivos? Texto para discussão $\mathrm{n}^{\mathrm{o}}$ 781, IPEA, fev. 2001. Disponível em < http://www.ipea.gov.br/ppp/index.php/PPP/article/viewFile/77/88>. acessos em 23 out. 2014.

DIAS, Leandro Martins e CAMPOS, Maurício. A Lei de Responsabilidade Fiscal: Aplicação e Importância. $1^{\circ}$ Conferência Internacional de Estratégia em Gestão, Educação e Sistemas de Informação. Goiânia, p. 173-185, jun/2012. Disponível em < http://www.prp.ueg.br/revista/index.php/ciegesi/article/view/768/814>. Acesso em 25 set. 2014.

DIVINO, José Ângelo Costa Do Amor; JUNIOR, Rogério Lúcio Soares Da Silva. Composição Dos Gastos Públicos e Crescimento Econômico Dos Municípios Brasileiros. Associação Nacional dos Centros de Pós-graduação em Economia ï ANPEC. Brasília/DF, v.13, n.3a, p.507ї528, set/dez 2012. Disponível em < http://www.anpec.org.br/revista/vol13/vol13n3ap507_528.pdf>. acessos em 28 out. 2014.

EASTERLY, William; REBELO, Sérgio. Fiscal policy and economic growth: an empirical investigation. Journal of Monetary Economics, v. 32, p. 417-458, 1993. Disponível em http://www.nber.org/papers/w4499.pdf acessos em 28 out. 2014 
FONSECA, Pedro Cezar Dutra; MONTEIRO, Sergio Marley Modesto. O Estado e suas razões: o II PND. Rev. Econ. Polit., São Paulo, v. 28, n. 1, mar. 2008 . Disponível em $<$ http://www.scielo.br/scielo.php?script=sci_arttext\&pid=S0101-

31572008000100002\&lng=pt\&nrm=iso>. acessos em $20 \quad$ ago. 2014. http://dx.doi.org/10.1590/S0101-31572008000100002.

FREITAS, Urandi Roberto Paiva; NETO, Armando Affonso de Castro; LÔU, Isaac Coimbra. Relação entre Gastos Públicos e Crescimento Econômico: uma análise com dados em painel para o Nordeste. Conj. \& Planej., Salvador, n.162, p.50-57, jan./mar. 2009. Disponível em http://www.sei.ba.gov.br/site/publicacoes/sumarios/c\&p162/c\&p162_pag_50.pdf>. acessos em 09 out. 2014

GIACOMONI, James. Orçamento Público. $14^{\mathrm{a}}$ Ed. Ampliada, revista e atualizada. São Paulo: Atlas, 2009.

GIAMBIAGI, Fabio; Et al. Economia Brasileira Contemporânea: 1945-2010, 2011 ï Rio de Janeiro. $2^{\circ}$ Edição. Elsevier.

GOUVEA, Raphael Rocha; LIMA, Gilberto Tadeu. Mudança estrutural e crescimento sob restrição externa na economia brasileira: uma análise empírica do período 19622006 com considerações sobre o II PND. Econ. soc., Campinas, v. 22, n. 1, abr. 2013.

Disponível em <http://www.scielo.br/scielo.php?script=sci_arttext\&pid=S010406182013000100004\&lng=pt\&nrm=iso>. acessos em 08 jan. 2015. http://dx.doi.org/10.1590/S0104-06182013000100004.

GONÇALVES, Elizânia de Araújo. GASTOS PÚBliCOS COM A EDUCAÇÃ̃o SUPERIOR: Evolução dos Gastos Federais com a Universidade de Brasília entre 2003 e 2010, 2013. Mestrado Profissionalizante em Economia do Programa Pós- 
Graduação em Economia da Universidade de Brasília. Disponível em < http://repositorio.unb.br/bitstream/10482/14050/1/2013_ElizaniaAraujoGoncalves.pdf>. acessos em 11 out. 2014

GREMAUD, Amaury Patrick. A Economia Brasileira Contemporânea, 2002 ï São Paulo. $4^{\circ}$ Edição. Atlas.

INEP, Instituto Nacional de Pesquisas Educacionais Anísio Teixeira. Provas e Gabaritos. Brasília. Disponível em $<$ http://portal.inep.gov.br/web/enem/edicoesanteriores/provas-e-gabaritos>. Acesso em 20 mai. 2015.

IBOVESPA. Veja a trajetória da inflação, Ibovespa e o câmbio antes e depois do Plano Real. Portal IG. São Paulo. 2012. Disponível em < http://economia.ig.com.br/2012$\underline{\text { 07-02/veja-a-trajetoria-da-inflacao-ibovespa-e-o-cambio-antes-e-depois-do-plano- }}$ real.html> Acesso em 27 mai. 2015.

KEYNES, John Maynard. Teoria Geral do Emprego, do Juro e da Moeda. São Paulo: Editora Nova Cultural, 1996.

LAMEIRA, Valdir de Jesus. Uma revisão sobre a economia brasileira e o mercado financeiro após o Plano Real: as mudanças e a evolução do mercado de capitais entre 1995 e 2002. Rev. contab. finanças, São Paulo , v. 15, n. 35, ago. 2004 . Disponível em $<$ http://www.scielo.br/scielo.php?script=sci_arttext\&pid=S151970772004000200008\&lng=pt\&nrm=iso> acessos em 15 set. 2014. http://dx.doi.org/10.1590/S1519-70772004000200008.

LOPES, Tiago Camarinha. A política do plano real estudada a partir da combinação da proposta Larida com o ajuste fiscal. Revista Análise. Porto Alegre, v. 21, n. 2, p. 187- 
197 ,

jul./dez.

2010.

Disponível

em

http://revistaseletronicas.pucrs.br/ojs/index.php/face/article/viewFile/7569/6606>. Acesso em 23 set. 2014.

MACIEL, Pedro Jucá. Finanças públicas no Brasil: uma abordagem orientada para políticas públicas. Rev. Adm. Pública, Rio de Janeiro , v. 47, n. 5, out. 2013. Disponível em <http://www.scielo.br/scielo.php?script=sci_arttext\&pid=S003476122013000500007\&lng=pt\&nrm=iso>. acessos em 31 jan. 2015. http://dx.doi.org/10.1590/S0034-76122013000500007.

MATIAS-PEREIRA, José. Finanças Públicas: A Política Orçamentária no Brasil. $5^{\circ}$ Edição ï São Paulo: Atlas, 2010.

MEC, Ministério da Educação. ENEM 2013 Registra Número Recorde de Inscritos. Brasília. Disponível em < http://redecomunicadores.mec.gov.br/noticias/4018-enem-2013registra-numero-recorde-de-inscritos>. Acesso em 20 mai. 2015.

Portaria 126/2012. Análise sobre a Expansão das Universidades Federais

2003 a 2012. Brasília. 2012 Disponível em:<
http://portal.mec.gov.br/index.php?option=com_docman\&task=doc_download\&gid=1238 6\&Itemid $=>$. Acesso em 13/04/2014.

MERCADANTE, Aloizio. Fórum Estadão Brasil Competitivo. São Paulo. Brasil. 2013. Disponível em:

http://portal.mec.gov.br/index.php?option=com_content\&view=article\&id=19253>. Acesso em 12/04/2014.

NETTO, Antônio Delfim. Uma Visão Macro da Qualidade do Gasto no Setor Público, Secretária do Tesouro Nacional. 2010. Brasília. Disponível 
em<http://www3.tesouro.fazenda.gov.br/Sistema_Informacao_custos/downloads/5_Aprese ntacao_DelfimNetto.pdf> Acesso em 12/04/2014

OLIVEIRA, Heverson Cid. Gastos públicos federais $\mathbf{x}$ ensino superior $\mathbf{x}$ expansão da Universidade de Brasília - UnB. 2013. vi, 68 f., il. Dissertação (Mestrado em Economia) Universidade de Brasília, Brasília, 2013. Disponível em < http://repositorio.unb.br/bitstream/10482/13958/1/2013_HeversonCidOliveira.pdf>. acessos em 09 abr. 2015.

OLIVEIRA, Fabrício Augusto de. O Plano Cruzado: balanço e perspectivas. Lua Nova, São Paulo, v. 3, n. 3, mar. $1987 . \quad$ Disponível em $<$ http://www.scielo.br/scielo.php?script=sci_arttext\&pid=S010264451987000100004\&lng=pt\&nrm=iso>. acessos em $04 \quad$ set. 2014. http://dx.doi.org/10.1590/S0102-64451987000100004.

PEDRO CEZAR DUTRA FONSECA Ï Capítulo (11) publicado no Livro ñFormação Econômica do Brasilò / Organizadores: José Márcio Rego e Rosa Maria Marques. São Paulo: $\quad$ Saraiva, 2003. Disponível em< http://www8.ufrgs.br/decon/publionline/textosprofessores/FONSECA/capitulo11.pdf> Acesso em 23/07/14

PIANCASTELLI, Marcelo; PEREIRA, Francisco. Gasto público federal: análise da despesa não-financeira. IPEA, 1996. (Texto para Discussão, 431). Disponível em < http://www.dominiopublico.gov.br/download/texto/td_0431.pdf>. acessos em 28 jan. 2015.

REZENDE, Fernando Antônio. Finanças Públicas. $2^{\circ}$ Edição ï São Paulo: Atlas, 2010.

RIBEIRO, Márcio Bruno. Desempenho e eficiência do gasto público: uma análise comparativa entre o Brasil e um conjunto de países da América Latina. Finanças 
Públicas - XIII Prêmio Tesouro Nacional, IPEA, dez 2008. Disponível em < http://repositorio.ipea.gov.br/bitstream/11058/1665/1/TD_1368.pdf >. Acessos em 28 out. 2014

ROCHA, Fabiana; GIUBERTI, Ana Carolina. Composição do gasto público e crescimento econômico: um estudo em painel para os estados brasileiros. Econ. Apl., XXXIII Encontro Nacional de Economia, ANPEC, dez. 2005. Disponível em <http://www.anpec.org.br/encontro2005/artigos/A05A049.pdf>. Acessos em 29 set. 2014.

Composição do gasto público e crescimento econômico: uma avaliação macroeconômica da qualidade dos gastos dos Estados brasileiros. Econ. Apl., Ribeirão Preto ， v. 11, n. 4, dez. $2007 \quad$. $\quad$ Disponível em $<$ http://www.scielo.br/scielo.php?script=sci_arttext\&pid=S141380502007000400001\&lng=pt\&nrm=iso>. acessos em 27 out. 2014. http://dx.doi.org/10.1590/S1413-80502007000400001.

RODRIGUES, Rodrigo Vilela; TEIXEIRA, Erly Cardoso. Gasto público e crescimento econômico no Brasil: uma análise comparativa dos gastos das esferas de governo. Rev. Bras. Econ., Rio de Janeiro , v. 64, n. 4, dez. 2010 . Disponível em $<$ http://www.scielo.br/scielo.php?script=sci_arttext\&pid=S0034-

71402010000400005\&lng=pt\&nrm=iso>. acessos em $29 \quad$ set. 2014. http://dx.doi.org/10.1590/S0034-71402010000400005.

SACRAMENTO, Ana Rita Silva. Contribuições da Lei de Responsabilidade Fiscal para o avanço da Accountability no Brasil. Cadernos de Gestão Pública e Cidadania. São Paulo. Vol. 10. $\mathrm{N}^{\mathrm{o}}$ 47. Julho a Dezembro de 2005. Disponível em < http://ceapg.fgv.br/sites/ceapg.fgv.br/files/file/Cadernos/Cad47.pdf>. Acesso em 25 set. 2014. 
SANTOS, Fernando Soares dos. Financiamento Público das Instituições Federais de Ensino Superior ï IFES: Um Estudo da Universidade de Brasília - UnB. 2013. Mestrado em Economia do Programa Pós-Graduação em Economia da Universidade de Brasília. Disponível em http://repositorio.unb.br/bitstream/10482/14141/1/2013_FernandoSoaresdosSantos.pdf $>$. acessos em 17 abr. 2015

SOUZA, Antônio Ricardo de. As trajetórias do planejamento governamental no Brasil: meio século de experiências na administração pública. Revista do Serviço Público. Brasília. Vol. 55. N $\mathrm{N}^{\mathrm{o}}$ 4. Outubro a Dezembro de 2004. Disponível em < http://seer.enap.gov.br/index.php/RSP/article/view/254/259>. Acesso em 12 jan. 2015.

SOUZA, Vitor Pelizaro. Educação a da produtividade da economia moderna. FEA/USP. São Paulo. $\quad$ Brasil. 2012. Disponível em:< http://www.fea.usp.br/feaecon/econoteen/media/fck/File/Victor\%20PelizaroEducacao_a_base_da_produtividade_da_economia_moderna.pdf> Acesso em 14/04/2014.

SILVA, Romildo Araújo da. Evolução e dinâmica dos gastos do governo federal brasileiro no período 1995-2005, 2007, 92 f. Mestrado em Ciências Contábeis do Programa Multiinstitucional de Pós-Graduação em Ciências Contábeis da Universidade de Brasília, Universidade Federal da Paraíba, Universidade Federal de Pernambuco e Universidade Federal do Rio Grande do Norte. Disponível em < http://repositorio.unb.br/bitstream/10482/3413/1/2007_RomildoAraujodaSilva.pdf>. acessos em 09 out. 2014

STN, Secretária do Tesouro Nacional. Sobre o Tesouro Nacional. Brasília. Disponível em < http://www.tesouro.fazenda.gov.br/sobre-o-tesouro-nacional>. Acesso em 14 jan. 2015. 
Glossário. Brasília: STN, 2015. Disponível em < http://www3.tesouro.fazenda.gov.br/servicos/glossario/glossario_a.asp>. acessos em 18 mai. 2015.

MCASP, Manual de Contabilidade Aplicada ao Setor Público. $6^{\circ}$ Ed. Brasília: STN, 2014.

UNIVERSIDADE DE BRASÍLIA. Relatório de Gestão 2013. 2013. Fundação Universidade de Brasília. Brasília/DF.

Extensão. 2015. Fundação Universidade de Brasília. Brasília/DF. Disponível em < http://www.unb.br/extensao>. acessos em 18 mai. 2015.

Anuário Estatístico. 2014. Fundação Universidade de Brasília. Brasília/DF. Disponível em <http://www.dpo.unb.br/documentos/anuario/Anuario_2014.pdf>. acessos em 26 mai. 2015.

VELOSO, Fernando A.; VILLELA, André; GIAMBIAGI, Fabio. Determinantes do "milagre" econômico brasileiro (1968-1973): uma análise empírica. Rev. Bras. Econ., Rio de Janeiro , v. 62, n. 2, jun. 2008 . Disponível em $<$ http://www.scielo.br/scielo.php?script=sci_arttext\&pid=S003471402008000200006\&lng=pt\&nrm=iso>. acessos em 06 ago. 2014. http://dx.doi.org/10.1590/S0034-71402008000200006.

VICECONTI, Paulo Eduardo V.. O processo de industrialização brasileira. Rev. adm. empres., São Paulo , v. 17, n. 6, dez. 1977 . Disponível em $<$ http://www.scielo.br/scielo.php?script=sci_arttext\&pid=S003475901977000600003\&lng=pt\&nrm=iso>. acessos em 22 jul. 2014. http://dx.doi.org/10.1590/S0034-75901977000600003. 